July 1997

IDENTIFICATION OF THE SPAWNING, REARING, AND MIGRATORY REQUIREMENTS OF FALL CHINOOK SALMON IN THE COLUMBIA RIVER BASIN

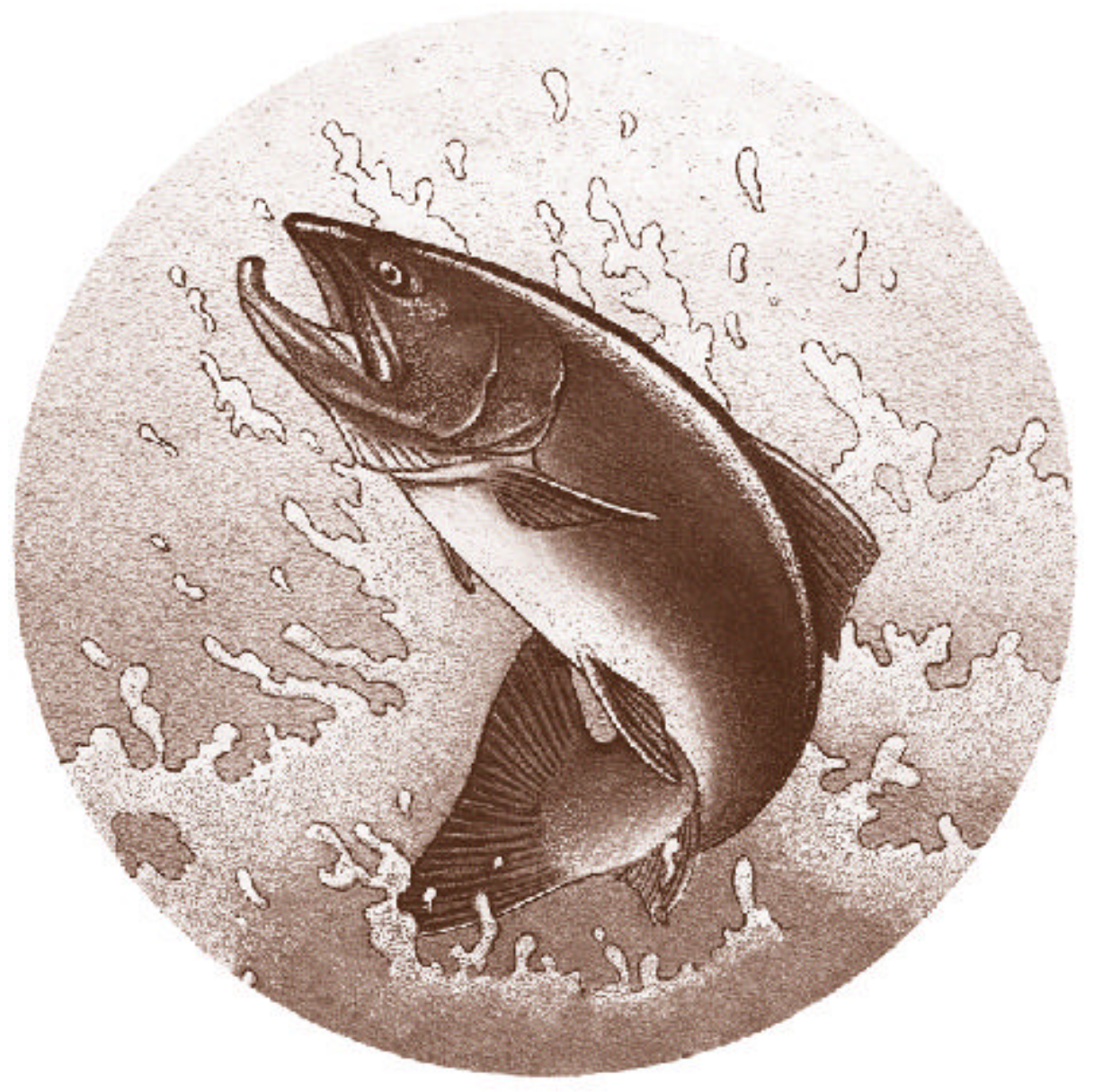

DOE/BP-21708-5 
This report was funded by the Bonneville Power Administration (BPA), U.S. Department of Energy, as part of BPA's program to protect, mitigate, and enhance fish and wildlife affected by the development and operation of hydroelectric facilities on the Columbia River and its tributaries. The views of this report are the author's and do $\mathrm{r}$ necessarily represent the views of BPA.

This document should be cited as follows:

Rondotf,Dennis W., Kenneth F. Tiffan, U.S. Geological Survey, Biological Resources Division, Columbia River Research Laboratory, U. S. Department of Energy, Bonneville Power Administration, Division of Fish and Wildlife, Project Number 199l-029, Contract Number DE-A17cl-1991BP2170X, 121 electronic pages (BPA Report DOE/BP-21708-5)

This report and other BPA Fish and Wildlife Publications are available on the Internet at: http://www.efw.bpa.gov/cgi-bin/efw/FW/publications.cgi

For other information on electronic documents or other printed media, contact or write to:

\author{
Bonneville Power Administration \\ Environment, Fish and Wildlife Division \\ P.O. Box 3621 \\ 905 N.E. 11th Avenue \\ Portland, OR 97208-3621
}

Please include title, author, and DOE/BP number in the request. 
This report was funded by the Bonneville Power Administration (BPA), U.S. Department of Energy, as part of BPA's program to protect, mitigate, and enhance fish and wildlife affected by the development and operation of hydroelectric facilities on the Columbia River and its tributaries. The views in this report are the author's and do not necessarily represent the views of BPA.

f-or additional copies of this report. write to

Bonneville Power Administration

Public Information Center -CKPS-1

P.O. Bbx 3621

Portland, OR 97208 


\title{
IDENTIFICATION OF THE SPAWNING, REARING, AND MIGRATORY REQUIREMENTS OF FALL CHINOOK SALMON IN THE COLUMBIA RIVER BASIN
}

\author{
Prepared by: \\ Dennis W. Rondotf \\ and \\ Kenneth F. Tiffan \\ U.S. Geological Survey \\ Biological Resources Division \\ Columbia River Research Laboratory \\ Cook, WA 98605 \\ Prepared for: \\ U.S. Department of Energy \\ Bonneville Power Administration \\ Environment, Fish and Wildlife \\ P.O. Box 3621 \\ Portland, OR 972018-362 I \\ Project Number 9 1-029 \\ Contract Number DE-AI79-91 BP2 17018
}

JULY 1997 
TABLE OF CONTENTS

Table of Contents . . . . . . . . . . . . . . . . ii

Executive Summary . . . . . . . . . . . . . . . . . iii

Acknowledgments . . . . . . . . . . . . . . . . vi

Chapter 1:

Fall chinook salmon spawning ground surveys in the snake

River,1995 . . . . . . . . . . . . . . . . . . . 1

Chapter 2:

Early life history and survival of natural subyearling

fall chinook salmon in the snake and Clearwater rivers

in1995. . . . . . . . . . . . . . . . . . . 18

Chapter 3:

Behavior of juvenile fall chinook salmon in the forebay

of a lower snake River reservoir . . . . . . . . . 48

Chapter 4:

Nearshore movements of juvenile fall chinook salmon in the

Columbia River... . . . . . . . . . . . . . 69

Chapter 5:

Osmoregulatory performance and migration behavior of

subyearling chinook salmon . . . . . . . . . . . 85 


\section{EXECUTIVE SUMMARY}

This document is the 1995 annual progress report for selected studies of fall chinook salmon Oncorbynchus tshawytscha conducted by the Biological Resources Division (BRD) of the U.S. Geological Survey and the U.S. Fish and Wildlife Service. Activities were funded by the Bonneville Power Administration (BPA) through funding of Project 91-029.

The decline in abundance of fall chinook salmon in the Snake River basin has become a growing concern. In 1992, Snake River fall chinook salmon were listed as "threatened" under the Endangered Species Act. Effective recovery efforts for fall chinook salmon cannot be developed until we increase our knowledge of the factors that are limiting the various life history stages. This study attempts to identify those physical and biological factors which influence spawning of fall chinook salmon in the free-flowing snake River and their rearing and seaward migration through Columbia River basin reservoirs.

Snake River fall chinook salmon spawning was generally a November event in 1995 as it was in past years. A total of 71 redds were counted by helicopter and ground truthing surveys in the Snake River. A total of 45 deep-water areas were searched for redds resulting in 30 redds being counted. The most concentrated group of redds was at $\mathrm{Rkm} 289.0 \quad(\mathrm{~N}=27)$. Results from 1994 and 1995 redd counts indicate that the majority of spawning has shifted to sites above the Grand Ronde River as compared to counts made from 1988-1993.

Juvenile fall chinook salmon were seined and tagged with Passive Integrated Transponder (PIT) tags in the snake and Clearwater rivers to describe rearing patterns, emigration behavior, and emigration timing. A total of 1,101 subyearling chinook salmon were seined in the upstream reach of the Snake River, 1,379 were seined in the downstream reach, and 781 were seined in the Clearwater River in 1995. We PIT tagged and released 569, 660, and 454 of the above fish in each respective reach and river. All of the subyearlings tagged in the upstream reach of the Snake River and Clearwater River and collected at Lower Granite Dam were fall chinook salmon based on electrophoresis. Eighty-three percent of PIT-tagged fish recaptured from the downstream reach of the Snake River were of the fall race. Survival to the tailrace of Lower Granite Dam of fish released in the Clearwater River was about one fourth $(0.175)$ of that of fish released in the upstream (0.676) and downstream (0.660) reaches of the Snake River. Of the subyearlings PIT tagged in the up and downstream reaches of the 
Snake River and Clearwater River in 1995, 0.2\%, 2.1\%, and 0.6\% were detected as yearlings in 1996.

Paired fyke nets were used in the Hanford Reach of the Columbia River to study the direction and timing of nearshore movements by juvenile fall chinook salmon over sand and cobble substrates. Catch rates were highest in May, and by June most fish had apparently emigrated from the nearshore area. The diel timing of peak movements became more nocturnal as the season progressed. During April and May, catches in the downstream fishing net were significantly greater than those in the upstream fishing net, but by June movement was no longer directional at the cobble site. Catches were highest from water less than 0.75 $m$ deep during April and May, but by June fish were collected equally from two trap depths. The difference in trap efficiency could not be explained by differences in the amount of water sampled per hour by the two traps, and probably indicates a shallow water preference.

Radio telemetry was used to examine the migratory behavior of subyearling fall chinook salmon through Little Goose Reservoir and its forebay in 1995 and 1996. Travel rates through the upper portion of the reservoir where water velocities are relatively high were rapid compared to that of the lower reach and forebay where velocity was reduced. Once in the Little Goose Dam forebay, radio-tagged smolts typically circled the area or went back upstream before passing the facility, and passage generally occurred in under two days. However, almost 20\% of tagged fish spent a week or more in the forebay and lower reservoir during both years. This delay in the immediate forebay area may be a potentially serious threat to the stock, especially if similar numbers of fish are delayed at other snake River hydropower facilities.

Premigrant and migrant subyearling chinook salmon challenged in seawater showed increasing osmoregulatory competence with increasing size and date. However, fish did not develop full seawater competence until they became active emigrants at McNary Dam. Gill ATPase followed a trend of increasing activity until late June then a decline throughout the remainder of the summer as in previous years. Subyearling chinook salmon showed their greatest preference for saline water in late June and early July although there was continued use of saltwater through August. Migratory behavior was tested in laboratory experiments and showed that subyearling chinook salmon displayed the most net downstream movement at velocities of $15-45 \mathrm{~cm} / \mathrm{s}$ early in the season. Fish were generally more active during the day than at night, but movement downstream was more direct at night. The timing of osmoregulatory development and migratory behavior may 
confer a survival advantage on fish that migrate early in the season under more favorable migratory conditions. 


\section{ACKNOWLEDGMENTS}

We thank individuals in the Idaho Department of Fish and Game, Idaho Power Company, U.S. Fish and Wildlife Service, Washington Department of Fish and Wildlife, U.S. Army Corps of Engineers, National Marine Fisheries Service, Nez Perce Tribe and Fish Passage Center that assisted with the project activities. We extend special thanks to our colleagues at the Biological Resources Division and the Idaho Fishery Resource Office of the U.S. Fish and Wildlife Service for their assistance. We gratefully acknowledge reviewers for the valuable comments and suggestions which we have incorporated into this report. We appreciate the assistance of Debbie Docherty, Project Manager, Bonneville Power Administration. 
Fall Chinook Salmon Spawning Ground Surveys in the Snake River, 1995

by

A.P. Garcia, W.P. Connor, R.D. Nelle, R.D. Waitt, E.A. Rockhold, and R.S. Bowen

U.S. Fish and Wildlife Service Idaho Fishery Resource Office Ahsahka, Idaho 83520, USA 


\section{Introduction}

Spawning ground surveys were conducted in 199.5 as part of a Snake River fall chinook salmon Oncorbynchus tshawytscha study begun in 1991. Observations of fall chinook salmon spawning in the snake River were limited to infrequent redd counts in the years prior to 1987 (Haas 1965, Irving and Bjornn 1981, Witty 1988). From 1987-1990, aerial surveys were conducted on a limited basis by an interagency team and reported by the Washington Department of Fisheries (WDFW; Seidel and Bugert 1987, Seidel et al. 1988, Bugert et al. 1989-1991, and Mendel et al. 1992). Starting in 1991, the U.S. Fish and Wildlife Service (USFWS), and other cooperating agencies and organizations, expanded the scope of spawning ground surveys to include: (1) additional aerial surveys to improve redd counts and provide data on spawn timing; (2) the validation (ground truthing) of aerial surveys to improve accuracy; and (3) underwater searches to locate redds in water too deep to allow detection from the air (Connor et al. 1993; Groves 1993; Garcia et al. 1994a, 1994b, 1996).

The objective of this report is to use counts of fall chinook salmon redds to describe spawning distribution and timing in the Snake River in 1995. We present data collected from 1987 to 1990 for historic perspective, and data we collected from 1991-1994 for comparison with data collected in 1995.

\section{Study Area}

In 1995, the study area included the Snake River from Hells Canyon Dam to the head of Lower Granite Reservoir near Asotin, Washington (Figure 1). We describe specific locations within this area using river kilometers (Rkm) and landmarks derived from U.S. Army Corps of Engineers (COE) navigation charts (COE 1990) and U.S. Geological Survey topographical maps. 


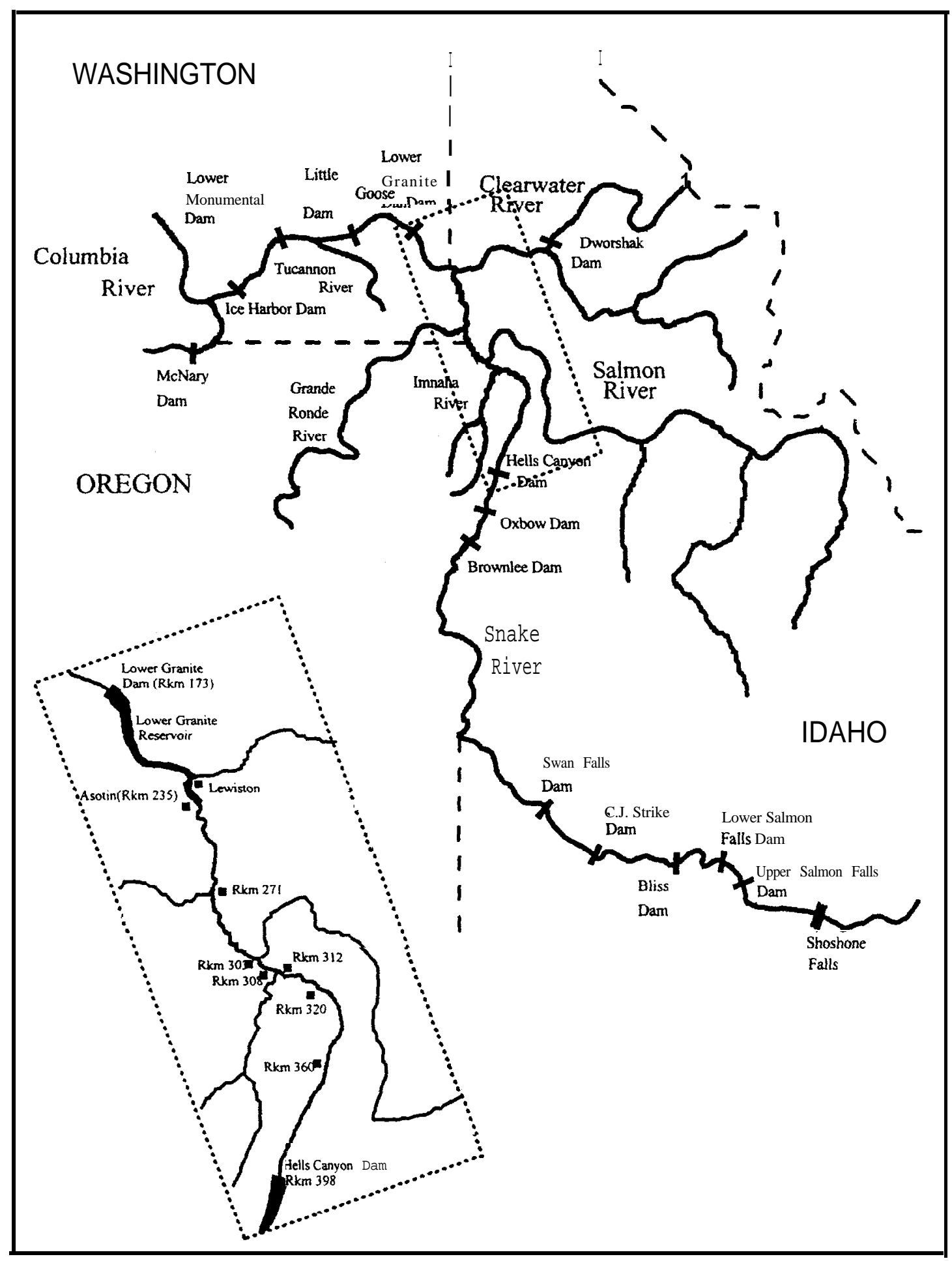

Figure I.- Map of the Snake River drainage featuring major tributaries, and inset showing river kilometers (Rkm) for reference to spawning areas, the head of Lower Granite Reservoir near Asotin, Washington, at Rkm 235, and Hells Canyon Dam at Rkm 398. 


\section{Methods}

\section{Aerial surveys, Ground Truthing, and Deep-water Searches}

We scheduled eight aerial surveys to be conducted once a week (6-8-d intervals) beginning on 23 October (week 43 in 1995). Surveys were made by two observers in a Hiller 12-E helicopter as it traveled from Asotin, Washington (Rkm 235) to Hells Canyon Dam (Rkm 398) at an altitude of $<200 \mathrm{~m}$. When a potential redd was observed, one of the observers marked the redd location on a $\mathrm{COE}$ navigation chart while the other made a sketch of the redd location relative to land features. Once a redd was counted, it was not counted again on subsequent surveys.

Potential redds that were difficult to observe from the air or had an abnormal shape or size were re-examined (ground truthed) from a boat or using an underwater camera. Aerial redd counts were adjusted based on ground-truthing observations.

We searched for redds in areas greater than $3 \mathrm{~m}$ deep (deepwater areas) using the same approach used in 1994 (Garcia et al. 1996), except for a change in mapping technique and search strategy. In 1994 and 1995, we used a Criterion 4001 electronic distance measuring device to determine the coordinates used for mapping redd locations. However, in 1994 we recorded coordinates by hand then transferred the data onto a computer to create maps, whereas in 1995, coordinates were automatically entered into a Corvallis MicroTechnology, Inc. MC-V data logger, then mapped using Laser-Walkabout computer software.

In 1994, we used a three-step strategy for redd searches in deep-water areas. First, we conducted a "low-intensity" search in a zig-zag pattern. If we encountered a redd, we then conducted an "unlimited" search without regard to search pattern, followed by a "high-intensity" search along equally spaced (4.6m) cross sections. We found high intensity searches were less effective than low intensity searches, but we were unable to assess the effectiveness of unlimited searches (Garcia et al. 1996). Based on these findings, in 1995 we used the lowintensity search method followed by the unlimited search method if we encountered a redd.

Of 91 deep-water areas known to have suitable spawning substrates (P. A. Groves, Idaho Power Company, personal

\footnotetext{
'Mention of trade names does not imply endorsement by the U.S. Government.
} 
communication), 42 were scheduled to be searched by USFWS

personnel, and 43 by Idaho Power Company personnel using the same search methods. The remaining sites were not targeted for search due to time constraints.

Results

\section{Aerial Surveys, Ground Truthing, and Deep-weiter Searches}

We report here only redd counts that we made in the snake River in 1995. The Nez Perce Tribe conducted redd counts in the Clearwater, Salmon, Imnaha, and Grand Ronde rivers, but their results are not reported here.

A total of 71 redds were observed in the Snake River above Lower Granite Reservoir in 1995 (Table 1). We conducted seven aerial surveys (Table 2) and observed 41 redds, eight of which were not judged to be redds until they were ground truthed. Visibility was good during the first three surveys. Visibility was estimated at less than $1 \mathrm{~m}$ between Asotin and the Grande Ronde River (Rkm 271.4) on the next three surveys, and about 1$1.5 \mathrm{~m}$ between the Grande Ronde and Salmon (Rkm 303) rivers during the fifth and sixth surveys. High river flows (Figure 2 and 3) and turbidity prevented us from searching downstream of the Salmon River during the seventh survey, and from conducting the eighth scheduled survey altogether.

A total of 30 redds were counted in deep-water areas in 1995 (Table 3). USFWS personnel searched 24 deep-water areas, and Idaho Power Company personnel (Groves and Chandler 1996) searched 21 areas (Table 4). Due to high turbidity, no deep-water areas were searched below the mouth of the Grande Ronde River in 1995, and only three areas (Rkm 294.6, Rkm 278.4, and Rkm 289.0) were searched between the Grande Ronde and Salmon rivers.

\section{Time of Spawning and Redd Distribution}

Redds were observed during our first flight indicating that fall chinook salmon spawning began before 23 October (week 43; Table 2; Figure 4). The highest count occurred on 6 November (week 45) and the last redd was observed on 27 November (week 48). No new redds were observed on the last aerial survey (week 49). 
Table 1.-Number of fall chinook salmon redds counted in the Snake River by search method and year, 1987-1995. Data sources and methods for collecting data from 1987-1994 can be found in Garcia et al. (1996). No underwater searches were conducted from 1987-1990.

\begin{tabular}{llllllllll} 
Sear \\
\cline { 2 - 8 } & 1987 & 1988 & 1989 & 1990 & 1991 & 1992 & 1993 & 1994 & 1995
\end{tabular}

\begin{tabular}{llllllllll}
\hline Air and ground & 66 & 57 & 58 & 37 & 41 & 47 & 60 & 53 & 41 \\
Underwater & & & & & 5 & 0 & 67 & 14 & 30 \\
\cline { 2 - 9 } & & & & & & & & & \\
Totals & 66 & 57 & 58 & 37 & 46 & 47 & 127 & 67 & 71 \\
\hline
\end{tabular}


Table 2. - New fall chinook salmon redds counted in 1995 during aerial surveys of the Snake River. Counts are presented by river kilometer (Rkm), landmark, week, and day. Surveys covered the Snake River from Asotin, Washington (Rkm 235), to Hells Canyon Dam (Rkm 398). Counts were adjusted based on ground-truthing observations. An empty cell indicates no survey was conducted at the corresponding river kilometer.

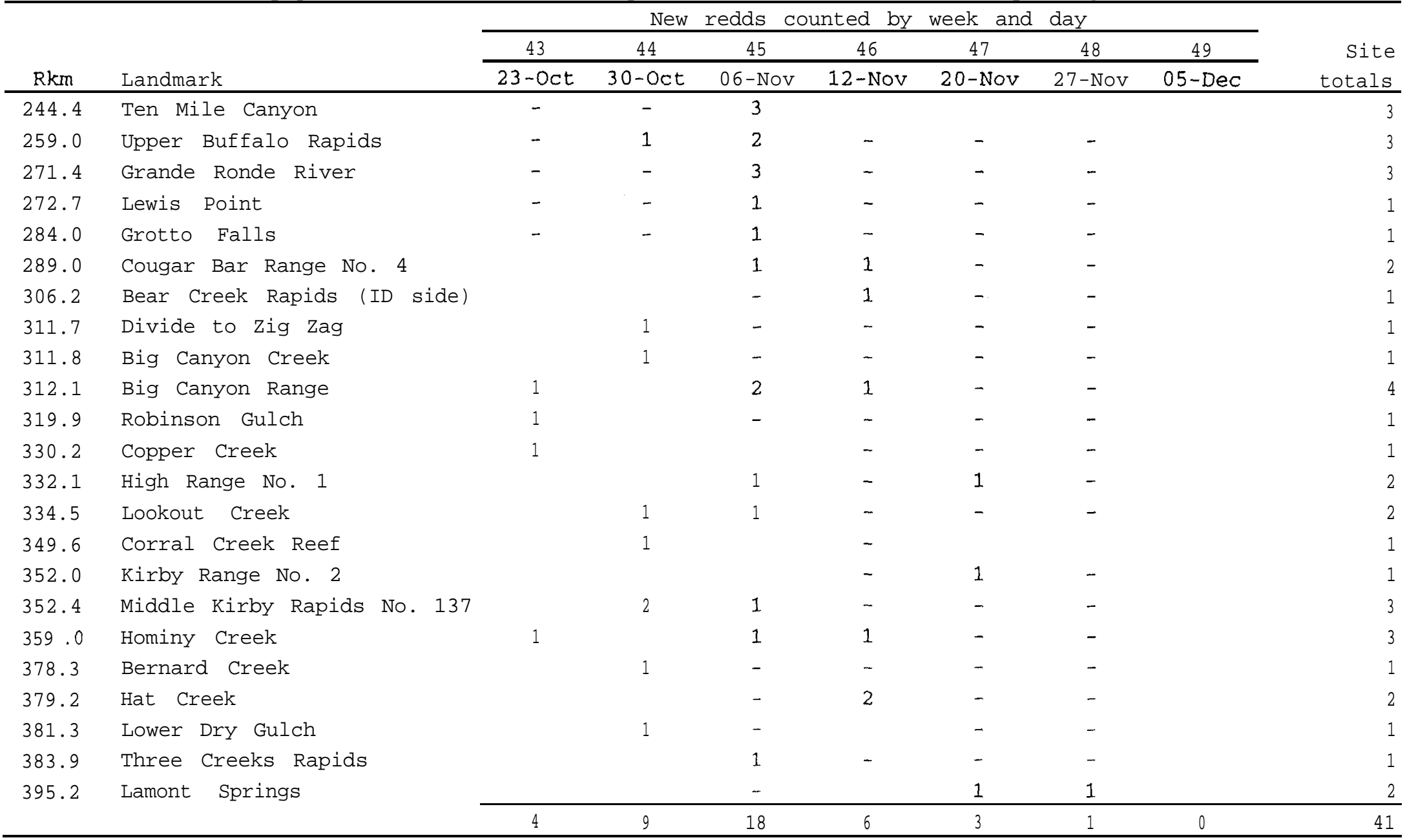




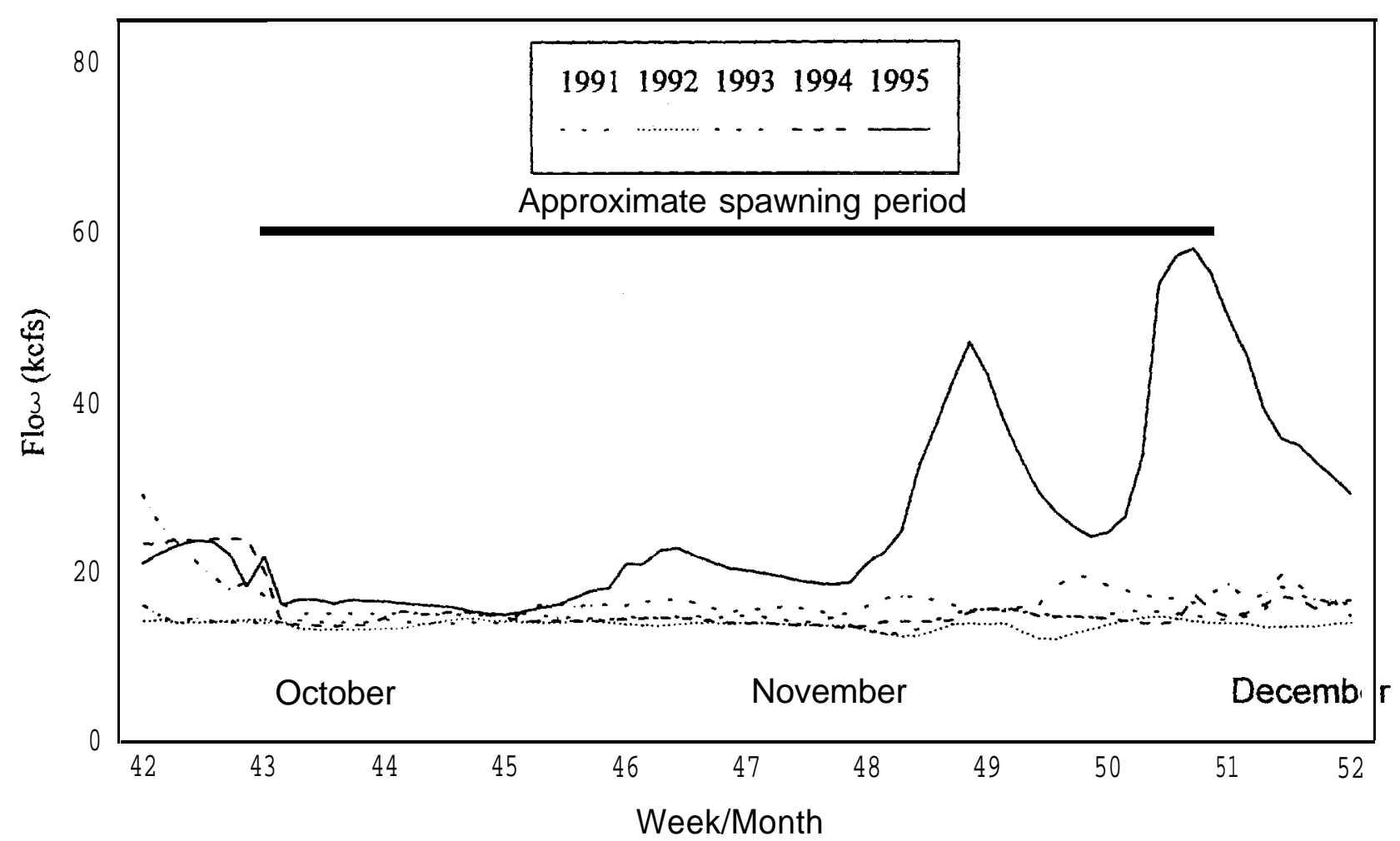

Figure 2.-Daily average Snake River discharge (kcfs) at the USGS Anatone Gage (Rkm 270) near Heller Bar.

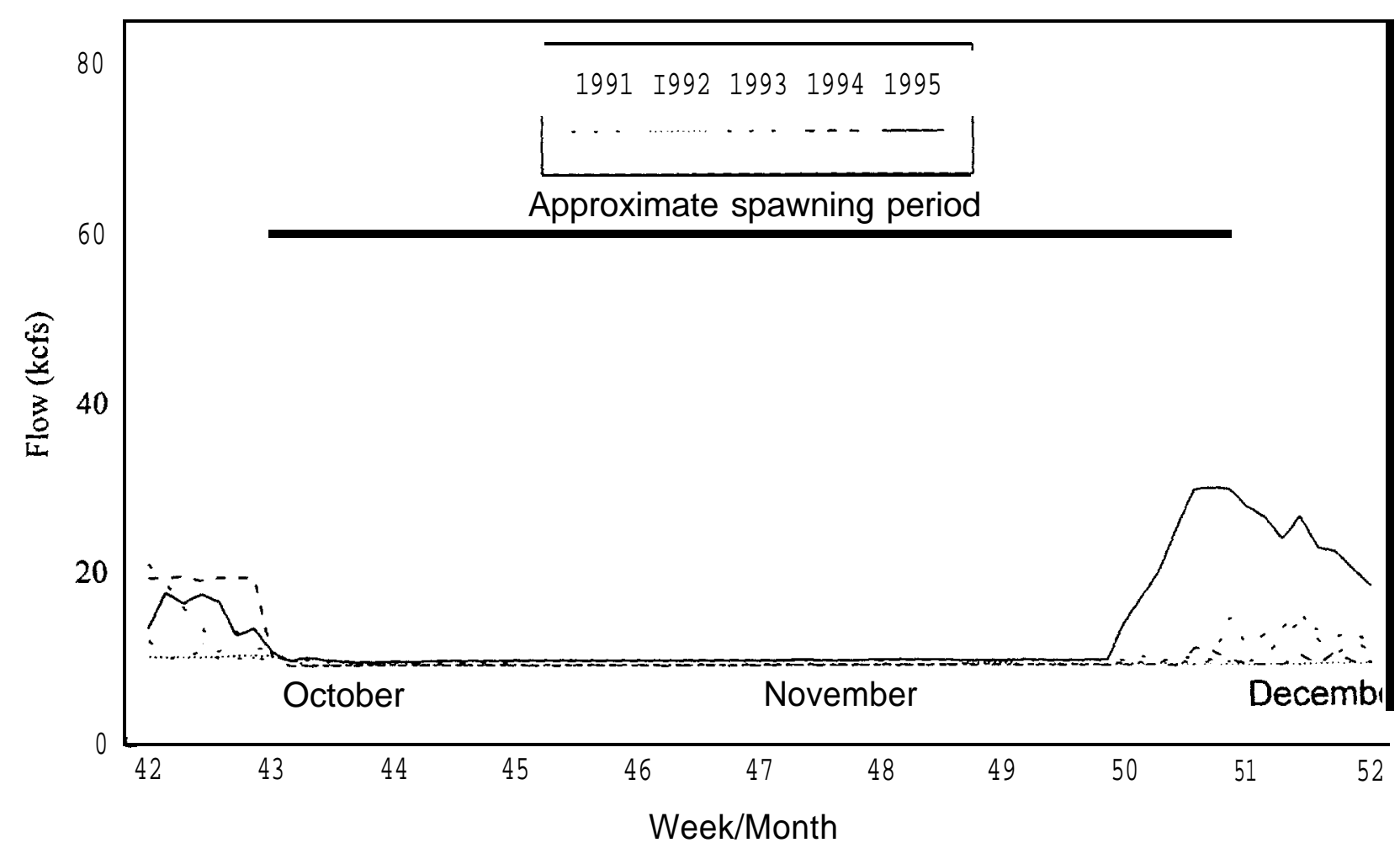

Figure 3.-Daily average Snake River discharge (kcfs) at Hells Canyon Dam (Rkm 398). 
Table 3.-Number of fall chinook salmon redds counted in deepwater areas of the Snake River by river kilometer (Rkm), landmark, and year, 1991-1995 (Connor et al. 1993; Garcia et al. 1996; Groves and Chandler 1996). A dash (-) indicates no search was conducted at the corresponding river kilometer.

Rkm Landmark

Year

$\begin{array}{lllll}1991 & 1992 & 1993 & 1994 & 1995\end{array}$

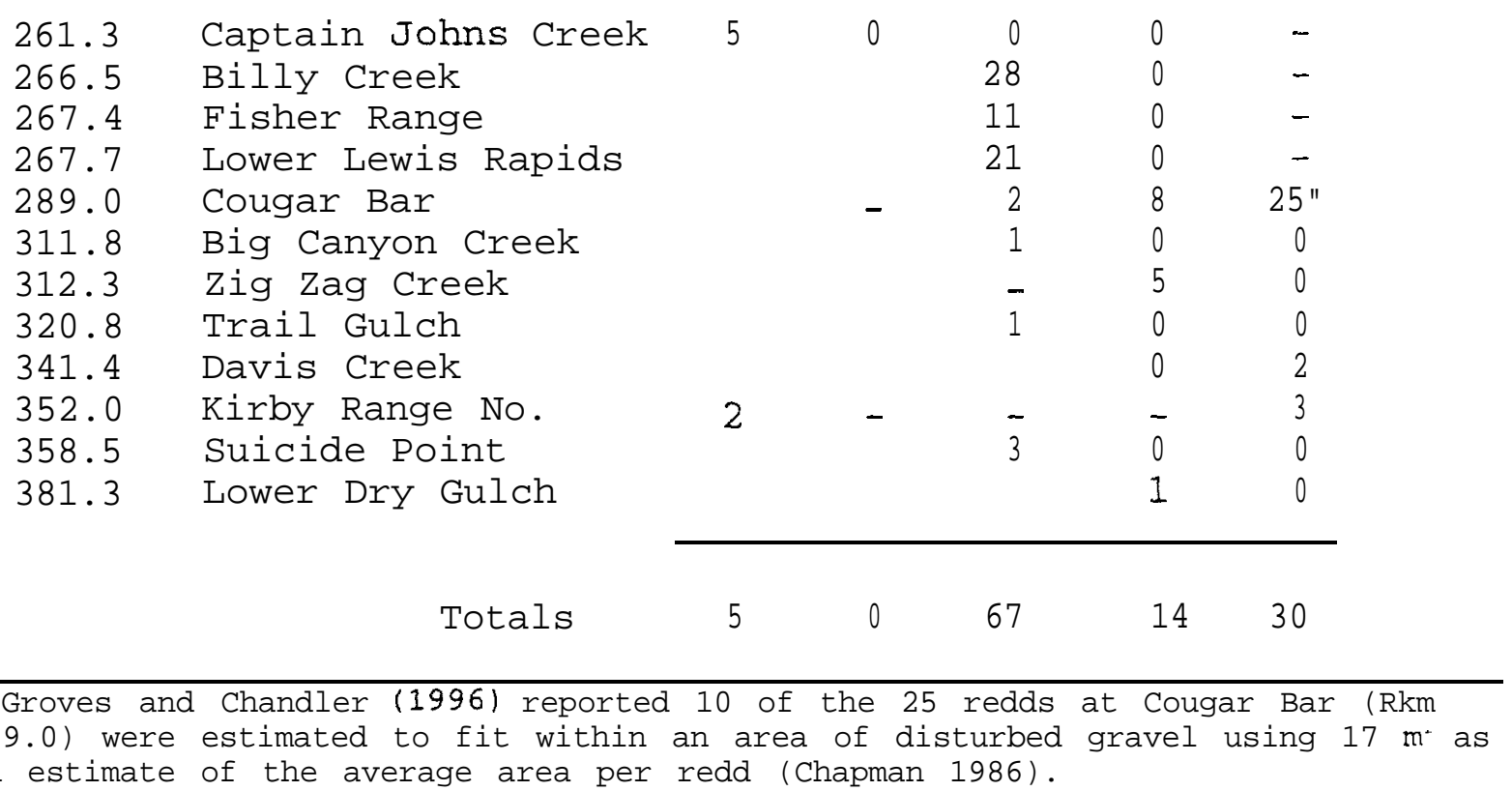


Table 4 .-Number of different deep-water areas searched for fall chinook salmon redds in the snake River grouped by investigator and year, 1991-1995 (Connor et al. 1993; Garcia et al. 1994, 1996; Groves and Chandler 1996).

Investigator

Areas searched by year

$\begin{array}{lllll}1991 & 1992 & 1993 & 1994 & 1995\end{array}$

\begin{tabular}{lrrrrrr} 
U.S. Fish and Wildlife Service & 1 & 3 & 6 & 44 & 24 \\
Idaho Power Company & & 0 & 0 & 45 & 35 & 21 \\
\cline { 3 - 7 } & Totals & 1 & 3 & 51 & 79 & 45
\end{tabular}




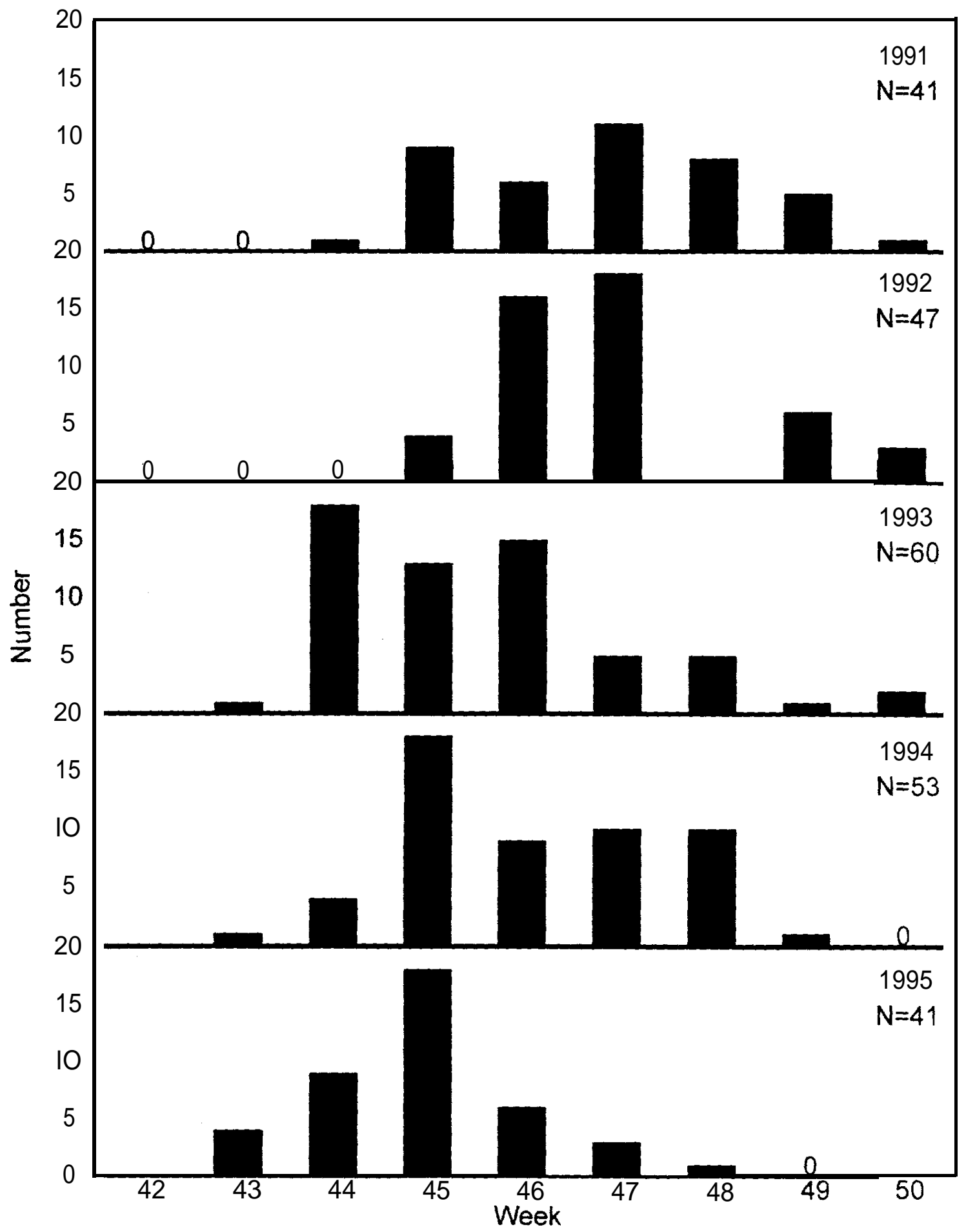

Figure 4.- Fail chinook salmon redds counted in the Snake River during aerial surveys with ground-truthing (zeros indicate aerial searches were conducted but no redds were observed). 
Redds were distributed between Rkm 244 and Rkm 396 in 1995 (Tables 2 and 3; Figure 5), based on observations from all search methods. We observed redds in seven areas not known to be used by fall chinook salmon prior to 1995 (Garcia et al. 1996). New areas were at Rkm 284.0 near Grotto Falls, Rkm 306.2 on the Idaho side below Knight Creek, Rkm 341.4 at Davis Creek, Rkm 352.0 at Kirby Range No. 2, Rkm 352.4 above Middle Kirby Rapids No. 137, Rkm 378.3 near Bernard Creek, and Rkm 395.2 near Lamont Springs.

\section{Discussion}

Accuracy of redd counts in 1995 was good despite relatively poor observation conditions. We can compare the relative accuracy of redd counts between years using the ratio of adult fall chinook salmon counted at Lower Granite Dam, reduced by 36\% to account for fall-back (G.W. Mendel, WDFW, unpublished data), to the number of redds counted upstream (fish-to-redd ratio). In 1994 for example, 606 adult fish were counted at Lower Granite Dam (COE 1995) and 120 redds were counted upstream (USFWS 1995), thus the fish-to-redd ratio was $(606 \times 0.64) / 120$ or $3.23 / 1$. This compares to a fish-to-redd ratio of $3.53 / 1$ in 1995, which indicates the accuracy of redd counts were fairly close even though search conditions were different between years. In 1994, search effort was relatively high and observation conditions were generally good (USFWS 1995), but in 1995 search effort was limited due to flooding and high turbidity.

Another way to assess the accuracy of redd counts is by comparing the estimated number of female salmon passing Lower Granite Dam to the number of redds counted above the dam, based on the assumption that each female will create a redd. For example, 137 redds could be expected above Lower Granite Dam in 1994 based on 606 fish, a 36\% fall-back rate, and a 0.55:1 female:male ratio (Mendel et al. 1996). Since 120 redds were actually counted above Lower Granite Dam in 1994, then an estimated 17 redds (13\%) were missed. Using the same approach with data from 1995, an estimated 38 redds (25\%) were missed. Notably, these estimates increase to 31 redds (33\%) missed in 1994, and 68 redds (45\%) missed in 1995 if redds counted in deepwater areas of the snake River are not included in the calculations.

Assuming missed redds were evenly distributed in 1994, and mainly distributed in the Grande Ronde River in 1995 (USFWS 1996), we find that redd distribution in the Snake River has shifted in the last two years compared to the previous six years. Based on aerial observations from 1988-1993, 50\%-70\% of the redds observed each year were distributed downstream of the Grande 


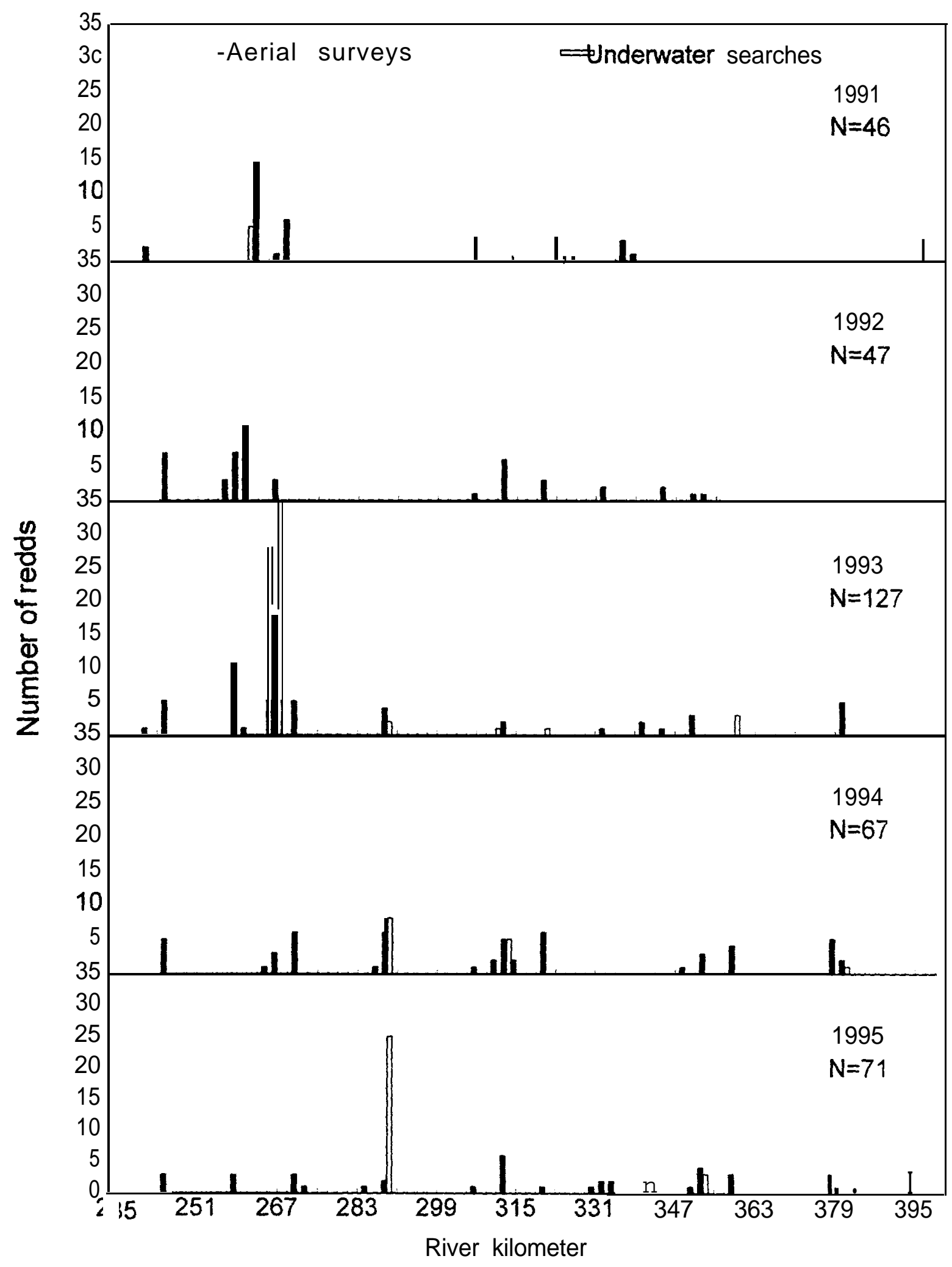

Figure 5.- Number of fall chinook salmon redds counted in the Snake River during aerial surveys with ground-truthing (dark bars), and underwater searches (light bars), 1991-1995 (data were grouped into 2-km intervals). 
Ronde River compared to 28\% in 1994, and 22\% in 1995. Some of the increased use above the Grande Ronde River has occurred between the Salmon and Grande Ronde rivers where the percent distribution of redds ranged from 0\%-7\% in 1988-1993, and 10\%-13\% in 1994-1995, based solely on aerial observations. When deepwater observations are factored in, the 1994-1995 percent distribution in this river reach ranges from 5\%-41\%. 
Bugert, R., P. Seidel, P. LaRiviere, D. Marbach, S. Martin, and L. Ross. 1989, Lower Snake Compensation Plan, Lyons Ferry Hatchery Evaluation Program, 1988 Annual Report. Cooperative Agreement 14-16-001-88519, U.S. Fish and Wildlife Service, Boise, Idaho.

Bugert, R., P. LaRiviere, D. Marbach, S. Martin, L. Ross, and D. Geist. 1990. Lower Snake Compensation Plan, Lyons Ferry Hatchery Evaluation Program, 1989 Annual Report. Cooperative Agreement 14-16-0001-89525, U.S. Fish and Wildlife Service, Boise, Idaho.

Bugert, R., C. Busack, G. Mendel, K. Petersen, D. Marbach, L. Ross, and J. Dedloff. 1991. Lower Snake Compensation Plan, Lyons Ferry Hatchery Evaluation Program, 1990 Annual Report. Cooperative Agreement 14-16-001-90525, U.S. Fish and Wildlife Service, Boise, Idaho.

Chapman, D.W., D.E. Weitkamp, T.L. Welsh, M.B. Dell, and T.H. Schadt. 1986. Effects of river flow on the distribution of chinook salmon redds. Transactions of the American Fisheries Society, 115:537-547.

COE (U.S. Army Corp of Engineers). 1990. Navigation charts of the Snake River, Oregon, Washington, and Idaho. Lewiston, Idaho to Johnson Bar. U.S. Army Corp of Engineers, Walla Walla District, Walla Walla, Washington.

COE (U.S. Army-Corp of Engineers). 1987-1996. Annual fish passage reports, 1987-1995, Columbia and Snake Rivers. North Pacific Division, U.S. Army Corps of Engineers, Portland and Walla Walla Districts.

Connor, W.P., A.P. Garcia, H.L. Burge, and R.H. Taylor. 1993. Fall chinook salmon spawning in free-flowing reaches of the Snake River. Pages 1-29 in D.W. Rondorf and W.H. Miller, editors. Identification of the spawning, rearing, and migratory requirements of fall chinook salmon in the Columbia River basin. 1991 Annual Report to Bonneville Power Administration, Contract DE-AI79-91BP21708, Portland, Oregon.

Garcia, A.P., W.P. Connor, and R.H. Taylor, 1994a. Fall chinook spawning ground surveys in the Snake River. Pages 1-19 in D.W. Rondorf and W.H. Miller, editors. Identification of the spawning, rearing, and migratory requirements of fall 
chinook salmon in the Columbia River basin. 1992 Annual Report to Bonneville Power Administration, Contract DEAI79-91BP21708, Portland, Oregon.

Garcia, A.P., W.P. Connor, and R.H. Taylor. 1994b. Fall chinook spawning ground surveys in the Snake River. Pages 1-21 in D.W. Rondorf and K.F. Tiffan, editors. Identification of the spawning, rearing, and migratory requirements of fall chinook salmon in the Columbia River basin. 1993 Annual Report to Bonneville Power Administration, Contract DE-AI7991BP21708, Portland, Oregon.

Garcia, A.P., W.P. Connor, R.D. Nelle, C. Eaton, R.S. Bowen, P.E. Bigelow, and E.A. Rockhold. 1996. Fall chinook spawning ground surveys in the Snake River, 1994. Pages 1-15 in D.W. Rondorf and K.F. Tiffan, editors. Identification of the spawning, rearing, and migratory requirements of fall chinook salmon in the Columbia River basin. 1994 Annual Report to Bonneville Power Administration, Contract DE-AI7991BP21708, Portland, Oregon.

Groves, P.A. 1993. Habitat available for, and used by, fall chinook salmon within the Hells Canyon Reach of the Snake River. Annual Progress Report 1992. Environmental Affairs Department, Idaho Power Company, Boise, Idaho.

Groves, P.A, and J.A. Chandler. 1996. A summary of fall chinook salmon (Oncorhynchus tshawytscha) redd surveys within the Hells Canyon reach of the Snake River, Idaho: 1991-1995. Report to the National Marine Fisheries Service, Silver Springs, Maryland.

Haas, J.B. 1965. Fishery problems associated with Brownlee, oxbow, and Hells Canyon Dams on the middle Snake River. Investigational Report Number 4. Fish Commission, Portland Oregon.

Irving, J.S. and T.C. Bjornn. 1981. Status of Snake River fall chinook salmon in relation to the Endangered Species Act. Prepared for the U.S. Fish and Wildlife Service, Portland, Oregon.

Mendel, G., K. Petersen, R. Bugert, D. Milks, L. Ross, J.Dedloff. and L. LaVoy. 1992. Lower Snake River Compensation Plan Lyons Ferry fall chinook salmon hatchery program. 1991 Evaluation Report. Cooperative Agreement 14-16-0001-91534, Washington Department of Fisheries report to the U.S. Fish 
and Wildlife Service, Lower Snake River Compensation Plan Office, Boise, Idaho.

Mendel G., J. Bumgarner, D. Milks, L. Ross, and J. Dedloff. 1992. Lower Snake River Compensation Plan Lyons Ferry fall chinook salmon hatchery program. 1995 Annual Report. Cooperative Agreement 14-48-0001-93539, Washington Department of Fisheries report to the U.S. Fish and Wildlife Service, Lower Snake River Compensation Plan Office, Boise, Idaho.

Seidel, P., R. Bugert. 1987. Lower Snake River Compensation Plan, Lyons Ferry Salmon Evaluation Program, 1986 Annual Report. Cooperative Agreement 14-16-0001-86521. U.S. Fish and Wildlife Service, Boise, Idaho.

Seidel, P., R. Bugert, P. LaRiviere, D. Marbach, S. Martin, and L. Ross. 1988. Lower Snake River Compensation Plan, Lyons Ferry Evaluation Program, 1987 Annual Report. Cooperative Agreement 14-16-0001-87512. U.S. Fish and Wildlife Service, Boise, Idaho.

USFWS (U.S. Fish and Wildlife Service). 1994. Memorandum, re: Counts of fall chinook salmon redds in the Snake River, and tributaries above Lower Granite Dam in 1993, March 3, 1994. Available Idaho Fishery Resource Office, P.O. Box 18, Ahsahka, ID 83520 .

USFWS (U.S. Fish and Wildlife Service). 1995. Memorandum, re: Counts of fall chinook salmon redds in the Snake, Grande Ronde, and Imnaha rivers in 1994, January 25, 1995. Available Idaho Fishery Resource Office, P.O. Box 18, Ahsahka, ID 83520 .

USFWS (U.S. Fish and Wildlife Service). 1996. Memorandum, re: Counts of fall chinook salmon redds in the Snake River and tributaries above Lower Granite Dam, 1995, March 6, 1995. Available Idaho Fishery Resource Office, P.O. Box 18, Ahsahka, ID 83520 .

USFWS (U.S. Fish and Wildlife Service). 1997. Memorandum, re: 1996 fall chinook salmon redd counts summary for the Snake River above Lower Granite Dam, February 25, 1997. Available Idaho Fishery Resource Office, P.O. Box 18, Ahsahka, ID 83520 .

Witty, K.L. 1988. Annual Fish Report. Wallowa Fish District. Oregon Department of Fish and Wildlife, Enterprise, Oregon. 
CHAPTER ' IWO

Early Life History and Survival of Natural Subyearling Fall Chinook Salmon in the Snake and Clearwater Rivers in 1995

by

William P. Connor and Theodore C. Bjornn Idaho Cooperative Fish and Wildlife Unit University of Idaho Moscow, Idaho 83843

Howard L. Burge and Aaron P. Garcia United States Fish And Wildlife Service Idaho Fishery Resource Office P.O. Box 18

Ahsahka, ID 83520

and

Dennis W. Rondorf

United States Geological Survey

Biological Resources Division

Columbia River Research Laboratory

$5501 \mathrm{~A}$ Cook-Underwood $\mathrm{Rd}$.

Cook, WA 98605 


\section{Introduction}

Snake River fall chinook salmon Oncorbynchustshareytscha have declined in abundance the last three decades and now managers are seeking methods to restore the population, Estimates of adult fish returning to the Snake River prior to 1957 number in the tens of thousands (Irving and Bjornn 1981), compared to a range of about 300-750 for 1991-1995 (Lavoy 1995). As a result, snake River fall chinook salmon were listed as threatened under the Endangered Species Act (USFWS 1988) in 1992 (NMFS 1992) and the Snake and Clearwater rivers were identified as critical habitat (NMFS 1995). Resource managers are attempting to recover the population of Snake River fall chinook salmon, but the fish are restricted to a small part of historical production areas.

Historically fall chinook salmon spawned in the main stem Snake River and the lower reaches of some tributaries. The majority of Snake River fall chinook salmon utilized habitat for spawning and rearing that is no longer accessible. Most spawning occurred in the vicinity of Marsing, Idaho (river kilometer 629; $232 \mathrm{~km}$ upstream of Hells Canyon Dam) prior to 1955 (Haas 1965). Access to spawning areas upstream of Hells Canyon Dam was blocked starting in 1955 by a three dam complex. In addition, four dams with fish ladders were built between 1961 and 1975, inundating the lower $230 \mathrm{~km}$ of the Snake River. After construction of the dams, the areas available for spawning included $167 \mathrm{~km}$ of freeflowing Snake River downstream of Hells Canyon Dam, and tributaries, such as the Imnaha, Salmon, Grande Ronde, and clearwater rivers. The main stem free-flowing snake River is regulated with a thermal regime partially controlled by the operation of the Hells Canyon Dam and other upstream dams. Flow and temperature were variables of interest to us because they may affect the time of spawning, fry emergence, and juvenile emigration by fall chinook salmon in the remaining habitat.

Documentation of past use by fall chinook salmon of the Clearwater River is vague and ambiguous (Schoning 1940; 1947). Conflicting reports were received by Schoning concerning the presence of chinook salmon in the Clearwater River upstream of Lewiston Dam (river $\mathrm{km} \mathrm{6.4),} \mathrm{which} \mathrm{lacked} \mathrm{adequate} \mathrm{fish} \mathrm{ladders}$ from 1927-1938. No fall chinook salmon or redds were seen during Schoning's 1940 surveys in the main stem Clearwater River upstream from the dam. Although Lewiston Dam was removed in 1971, Dworshak Dam was built on the North Fork of the Clearwater River in 1971 and has modified the flow and thermal regimes of the lower Clearwater River. The potential to produce fall chinook salmon in the Clearwater River with the altered temperature regime is probably better than before, but 
consistently fewer adults spawn in the Clearwater than in the Snake River.

Fall chinook salmon that spawn and rear in the Snake and Clearwater rivers are referred to as ocean-type chinook salmon. Healy (1991) divided chinook salmon populations into two life history strategies including "stream type" and "ocean type." Ocean-type chinook salmon populations generally migrate seaward within 3 months of emergence as subyearlings. Adults of oceantype chinook salmon migrate upstream during fall and spawning occurs soon after arrival at the spawning grounds.

Prior to our cooperative research with the National Marine Fisheries Service (Smith et al. in press, Connor et al. in press), estimates of survival for juvenile fall chinook salmon emigrating from the snake and Clearwater rivers were nonexistent. Additionally, biological and environmental attributes affecting survival were poorly understood. Development of the passive integrated transponder (PIT) tag (Prentice et al. 1990) allowed us to enumerate individual juvenile fish as they passed hydropower dams, and modeling protocols for individual markrecapture survival estimates (Cormack 1964; Jolly 1965; Seber 1965; Burnham et al. 1987; Smith et al. 1994; Iwamoto et al. 1994) enhanced analyses.

The objectives of this segment of our study were to (1) describe the early life history characteristics of naturally produced subyearling fall chinook salmon in the snake and Clearwater rivers, and (2) estimate survival for juvenile fall chinook salmon emigrating from the snake and Clearwater rivers to the tail race of Lower Granite Dam.

\section{Study Area}

The Snake River originates in Yellowstone National Park, Wyoming and drains about 240,300 $\mathrm{km}^{2}$. Completion of the Hells Canyon complex of dams; Brownlee Dam (1955; river km 456), Oxbow Dam (1961; river km 439) and Hells Canyon Dam (1967; river km 397) blocked passage to historic Snake River fall chinook salmon spawning grounds (Haas 1965; Irving and Bjornn 1981). The $167 \mathrm{~km}$ free-flowing reach presently used for spawning is mostly in Hells Canyon (river km 247 to 271; Figure 1). Hells Canyon, a sparsely vegetated chasm up to $1,676 \mathrm{~m}$ deep, was formed from a marine volcanic assemblage of flow rocks, basalt, and andesite.

The confluence of the Clearwater and Snake rivers is $224 \mathrm{~km}$ upstream of the confluence of the Snake and Columbia rivers (Columbia River river $\mathrm{km}$ 522). The Clearwater River drainage 


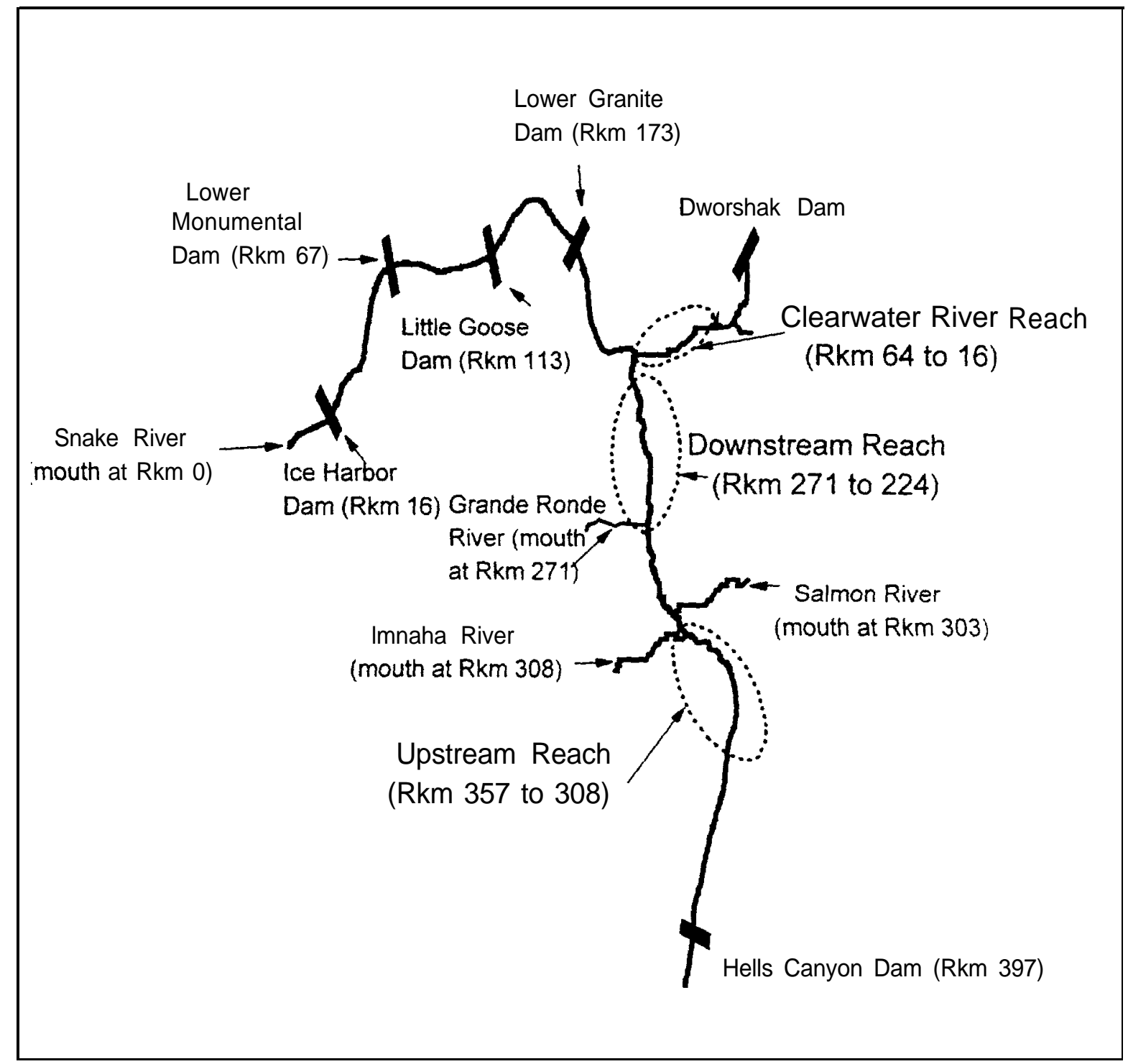

Figure 1 .-Study area including locations of the upstream and downstream reaches of the Snake River and the Clearwater River reach, 1995. 
originates in Idaho and drains approximately $24,786 \mathrm{~km}^{2}$. The lower reach of the Clearwater River, where fall chinook spawning occurs, was formed by volcanic activity and lava flows similar to that of the lower reach of the Snake River. Dworshak Dam, completed in 1971, is located on the North Fork Clearwater River about $2.0 \mathrm{~km}$ upstream from its confluence with the lower Clearwater River (river $\mathrm{km} \mathrm{65)}$ ). The North Fork provides about $40 \%$ of the Clear-water River's flow and regulates the river reach containing virtually all of the Clear-water River's fall chinook salmon spawning areas (Arnsberg and Statler 1996). Since 1991, cool water has been released from Dworshak Dam to augment summer flows and to cool the water in Lower Granite Reservoir during the summer to aid Snake River subyearling fall chinook salmon as they migrate seaward. In $1995,13.0 \mathrm{kcfs}$ of $10^{\circ} \mathrm{C}$ water was released from the dam for 48 d beginning 16 July.

Methods

\section{Data Collection}

We collected naturally produced subyearling fall chinook salmon for PIT-tagging and survival studies in the snake and Clearwater rivers with a beach seine. Seining sites were located in the main stem Snake River between river kilometers (Rkm) 271 and 224 (Figure 1). Spawning in upstream reaches of the snake River in 1994 allowed us to collect data above Rkm 308. These two reaches are described hereafter as upstream (Rkm 357 to Rkm 308) and downstream (Rkm 271 to $R k m$ 224). We seined sites in a 50-km reach of the Clearwater River between Rkm 64 and 14 . The number of seining sites on both rivers varied because of supplemental sampling to increase sample sizes for analyses. Supplemental sampling was done in both rivers over a 3 week period starting about $30 \mathrm{~d}$ after peak fry emergence. Seining was done weekly in both rivers starting in April and continued until water temperatures reached $20^{\circ} \mathrm{C}$ or the catch neared zero.

Sites were sampled once a week and normally seined three consecutive times in an upriver direction. Each net set started where the previous one ended. The beach seine had a weighted multistranded mudline, $0.48 \mathrm{~cm}$ mesh and was $30.5 \mathrm{~m} \times 1.8 \mathrm{~m}$ with a $3.9-\mathrm{m}^{3} \mathrm{bag}$. Each end of the seine was fitted with a bottom weighted brail, equal in length to net depth, and attached to 15.2-m lead ropes. The seine was set parallel to shore from the stern platform of a 6.7-m jet boat and then hauled straight into shore by both lead ropes. The net sampled approximately $465 \mathrm{~m}^{2}$ of river to a depth of $1.8 \mathrm{~m}$. 
Natural chinook salmon were aged and PIT tagged as described by Connor et al. (1996). We measured the fork length of natural subyearling chinook salmon to the nearest millimeter during PIT tagging and a subsample of fish were weighed for subsequent growth analysis. A subsample of PIT-tagged natural salmon recaptured at Lower Granite Dam was also weighed and measured. We recaptured a subsample of the PIT-tagged chinook salmon detected at Lower Granite Dam using a separation-by-code hardware and software system (S. Downing et al. unpublished protocol, National Marine Fisheries Service, Northwest Fisheries Science Center, Seattle, WA 98112-2097). Fish that were diverted by the separation-by-code system were scanned for a PIT-tag code and weighed and measured. A scale sample was taken for aging, and natural chinook salmon were labeled and frozen for subsequent race identification

We obtained water temperature data from the archives of the USFWS for the Swan Falls/Marsing reach of the Snake River from 1960-1970. The Swan Falls/Marsing reach is upstream of Brownlee Dam and water temperatures are representative of the Snake River prior to construction of the Hells Canyon complex of dams. Water temperature data downstream from Hells Canyon Dam were obtained from the United States Geological Survey (USGS) gage at Anatone WA (Rkm 269) for the period 1976-1981 to represent the post-dam period. These years were selected based on data quality and availability. Water temperatures prior to the construction of Dworshak Dam on the Clearwater River were available from 19601970 from the USGS gage at Spalding, ID (Rkm 19). Post-Dworshak Dam data from 1975-1982 were also obtained from the USGS gage at Spalding ID for comparative purposes.

\section{Data Analysis}

We made in-season and post-season identifications of race of natural chinook salmon to guide in-season PIT-tagging efforts and post-season analyses. In-season identification of race was made based on morphology of each fish that fit within our size limits. Salmon with pointed snouts, small down-turned eyes, and deep bodies were identified as natural fall chinook salmon. Fish that fit in our size limit, but had rounded snouts, large round eyes, and slender bodies, were identified as spring/summer chinook salmon. Post-season race determinations of each natural fish we recaptured at Lower Granite Dam were made by Washington Department of Fish and Wildlife (WDFW) personnel using tissue extracts, horizontal starch-gel electrophoresis (Abbersold et al. 1987), and Maximum Likelihood Estimation (MLE; A. Marshall, WDFW, P.O Box 43135, Olympia, Washington 98504-3135, unpublished 
protocol). We calculated the percentage of MLE estimated fall and spring/summer race chinook salmon in our sample, and

tabulated the results by river reach and race. We also aged each of the PIT-tagged fish recaptured at Lower Granite Dam and integrated the results with the race data.

We estimated emergence dates of fall chinook salmon fry to compare timing of emergence in the snake and Clearwater rivers. Date of emergence was calculated for each salmon captured by seine by subtracting $38 \mathrm{~mm}$ (estimated emergence length; Arnsberg et al. 1992) from the fork length at capture and dividing by the 1995 observed growth rate of $1.4 \mathrm{~mm} / \mathrm{d}$. We tested for differences among the emergence distributions using a two-sample KolmorovSmirnov test (KS test; SYSTAT 1994) and reported $P$ values.

We supplemented the 1995 emergence analysis, for the purpose of discussion, using a second method to estimate emergence dates of fall chinook salmon fry. Periods of concern were before and after construction of Hells Canyon and Dworshak dams. Median Julian date of spawning since 1991 in the Snake and Clearwater rivers has been 322 ( 17 to 18 November). We used the 17 November spawning date and 1000 Centigrade Temperature Units to estimate emergence (Piper et al. 1982) for both rivers before and after dams were constructed.

We characterized the rearing period of natural fall chinook salmon by graphing the number of salmon captured by date, river, and reach. We tested for differences among the capture distributions using a KS tests to calculate $P$ values. Mean fork length by week for each reach and river was calculated and graphed. Fork length of fish during emigration is an important factor which can affect survival. Mean fork lengths, on the last day of sampling each reach and river, were compared using Analysis of Variance and Tukey's test for Honestly Significant Difference (ANOVA; HSD; SYSTAT 1994).

Detection of PIT-tagged fall chinook salmon at the dams enabled us to determine the emigration timing through the lower Snake River and into the Columbia River. We demonstrated emigration timing of salmon from the snake and Clearwater rivers by combining and graphing the PIT-tag detection data from Lower Granite, Little Goose, Lower Monumental and McNary dams. Detection distributions were compared among the reaches and rivers using a KS test to calculate $P$ values. Each year a portion of the PIT-tagged subyearling chinook salmon hold over and emigrate the following spring as yearlings and we classified these as "residuals". We divided the number of PIT-tagged salmon, which were detected at a minimum of one dam, by the total 
number of PIT-tagged fish released by river and river reach to calculate the percentage of residuals.

High detection rates and release of bypassed PIT-tagged salmon back to the river allowed us to estimate survival to the tail race of Lower Granite Dam in 1995. The statistical model used to estimate survival from PIT-tag data was the Single Release version of the Cormack/Jolly-Seber survival probability model (Cormack 1964; Jolly 1965; Seber 1965; Burnham et al. 1987; Smith et al. 1994; Iwamoto et al. 1994). The survival of fall chinook salmon was estimated for naturally produced subyearling fall chinook salmon PIT tagged and released in the clearwater and Snake rivers in 1995.

By using the Single Release Model we assumed that a salmon's detection at a PIT-tag detection site did not affect the probability of: 1) its detection at downstream sites, and 2) its survival to a downstream site. We also assumed that the single Release Model accurately estimated sampling variability because replicate releases to test this assumption were not possible with natural fall chinook salmon in 1995. Iwamoto et al. (1994) found that all of the above model assumptions were satisfied and accurate precise survival estimates were obtained for hatchery reared yearling chinook salmon.

\section{Results}

\section{Race}

Subyearling fall chinook salmon dominated the racial composition of PIT-tagged fish recaptured at Lower Granite Dam in 1995 (Table 1). Every PIT-tagged fish, recaptured from upstream reach releases, was aged as a subyearling and estimated to be of the fall race. A small percentage of recaptured fish were subyearling and yearling spring/summer chinook salmon tagged in the downstream reach of the Snake River. Low detection of Clearwater River chinook salmon limited aging and electrophoretic analysis, but all fish recaptured were subyearlings and estimated to be fall chinook salmon. Three estimated spring/summer chinook salmon, tagged in the downstream reach of the Snake River, were classified correctly as spring/summer chinook salmon at tagging. No estimated fall chinook salmon were misclassified as spring/summer chinook salmon at tagging. We omitted estimated spring/summer chinook salmon, and fish classified during tagging as spring/summer chinook salmon, from subsequent analyses. All fish are referred to hereafter as subyearling fall chinook salmon. 
Table 1.-Results of aging, electrophoresis, and Maximum Likelihood Estimation of subyearling chinook salmon beach seined and PIT tagged in the upstream and downstream reaches of the Snake River and the Clearwater River and recaptured and sacrificed at Lower Granite Dam in 1995 (sprg/sum is an abbreviation for spring/summer).

\begin{tabular}{|c|c|c|c|c|c|c|}
\hline \multirow{2}{*}{ River } & \multirow{2}{*}{ Reach } & \multirow{2}{*}{$\begin{array}{l}\text { Number } \\
\text { sampled }\end{array}$} & \multicolumn{2}{|c|}{ Age (\%) } & \multicolumn{2}{|c|}{ Race (\%) } \\
\hline & & & 0 & 1 & Fall & Sprg/sum \\
\hline Snake & Upstream & 65 & 100 & 0 & 100 & 0 \\
\hline Snake & Downstream & 41 & 93 & 7 & 83 & 17 \\
\hline Clearwater & $\mathrm{n} / \mathrm{a}$ & 3 & 100 & 0 & 100 & 0 \\
\hline
\end{tabular}




\section{Early Life History}

We collected 1,101 juvenile fall chinook salmon in the upstream reach of the Snake River, 1,379 in the downstream reach, and 781 in the Clearwater River (Table 2). Fry emergence in the upstream reach of the Snake River (Figure 2; 13 April) was significantly earlier $(P<0.001)$ than in the downstream reach of the Snake River (25 April). Fry emergence in both reaches of the Snake River was significantly earlier $(P$ C $0.001 ; P$ C 0.001$)$ than in the Clearwater River (24 May). The cause of the differences in fry emergence in 1995 was due to water temperature (Figure 3). Mean water temperature during spawning from 21 October to 7 December was warmest in the upstream reach of the Snake River $\left(10.9 \pm 2.9^{\circ} \mathrm{C}\right)$, followed by the downstream reach of the Snake River $\left(8.9 \pm 2.6^{\circ} \mathrm{C}\right)$, and the Clearwater River $\left(4.3 \pm 2.3^{\circ} \mathrm{C}\right)$. Mean water temperature remained higher through fry emergence in the upstream and downstream reaches of the snake River $\left(6.6 \pm 2.5^{\circ} \mathrm{C} ; 6.7 \pm 2.9^{\circ} \mathrm{C}\right)$ than in the Clearwater River $\left(5.0 \pm 3.2^{\circ} \mathrm{C}\right)$.

Capture dates of subyearling fall chinook salmon varied among the upstream and downstream reaches of the snake River and the Clearwater River (Table 2; Figure 4). We captured fish significantly earlier $(P<0.001)$ in the upstream reach of the Snake River (median $=28$ May) than in the downstream reach (median $=4$ June). We captured salmon significantly later in the Clearwater River (median $=2$ July) than in either snake River reach $(P<0.001$; for both comparisons $)$.

Subyearling fall chinook salmon from the upstream reach of the Snake River maintained the highest weekly mean fork lengths of the three reaches sampled (Table 2; Figure 5). Mean fork length generally increased each week until fish left near shore areas and sampling was discontinued. Overall mean weekly fork length of salmon captured in the upstream reach of the snake River was greater than for fish collected in the downstream reach of the Snake River and the Clearwater River, but the overall difference was only 3 to $5 \mathrm{~mm}$ fork length (Table 2). Mean fork length of salmon, the last week of sampling, differed significantly among reaches $(P<0.000)$. Statistical significance was attributable to the small size of Clearwater River fish.

We PIT tagged 569, 660, and 454 subyearling fall chinook salmon in the upstream and downstream reaches of the snake River and in the Clearwater River (Table 3). Tagging occurred over a more protracted time period in the downstream reach of the snake River (86 d) than in the upstream reach of the Snake River (49 d) or Clearwater River $(64 \mathrm{~d})$. Median dates of tagging were 28 
Table 2.-Number of subyearling fall chinook salmon captured by week in the upstream and downstream reaches of the Snake River and in the Clearwater River in 1995. Mean weekly fork length

(FL) by week (starting on Sundays) and total number captured (N) are also given.

\begin{tabular}{|c|c|c|c|c|c|c|}
\hline \multirow{2}{*}{ Week } & \multicolumn{2}{|c|}{$\begin{array}{l}\text { Snake River } \\
\text { upstream reach }\end{array}$} & \multicolumn{2}{|c|}{$\begin{array}{c}\text { Snake River } \\
\text { downstream reach }\end{array}$} & \multicolumn{2}{|c|}{$\begin{array}{c}\text { Clearwater } \\
\text { River }\end{array}$} \\
\hline & number & FL & number & FL & number & F L \\
\hline 2 April & 7 & 41 & 16 & 44 & 1 & $\mathrm{n} / \mathrm{a}$ \\
\hline 09 April & 20 & 43 & 2 & 52 & 0 & \\
\hline 16 April & 21 & 42 & 16 & 45 & 0 & \\
\hline 23 April & 61 & 46 & 65 & 46 & 0 & \\
\hline 30 April & 103 & 49 & 83 & 46 & 0 & \\
\hline 07 May & 104 & 55 & a5 & 49 & 1 & $\mathrm{n} / \mathrm{a}$ \\
\hline 14 May & 40 & 58 & 142 & 50 & 0 & \\
\hline 21 May & 170 & 68 & 73 & 56 & 9 & 51 \\
\hline 28 May & 333 & 76 & 170 & 60 & 9 & 52 \\
\hline 04 June & 146 & 83 & 361 & 69 & 24 & 54 \\
\hline 11 June & 79 & 90 & 201 & 75 & 40 & 57 \\
\hline 18 June & 17 & 95 & 82 & a2 & 140 & 53 \\
\hline 25 June & & & 56 & 83 & 165 & 63 \\
\hline 2 July & & & 25 & 93 & 152 & 77 \\
\hline 09 July & & & & & 172 & 72 \\
\hline 16 July & & & & & 52 & 71 \\
\hline 23 July & & & & & 16 & 76 \\
\hline $\mathrm{N}$ & 1,101 & & 1,379 & & 781 & \\
\hline Mean FL \pm SD & & $69 \pm 16$ & & $64 \pm 16$ & & $5 \pm 16$ \\
\hline
\end{tabular}




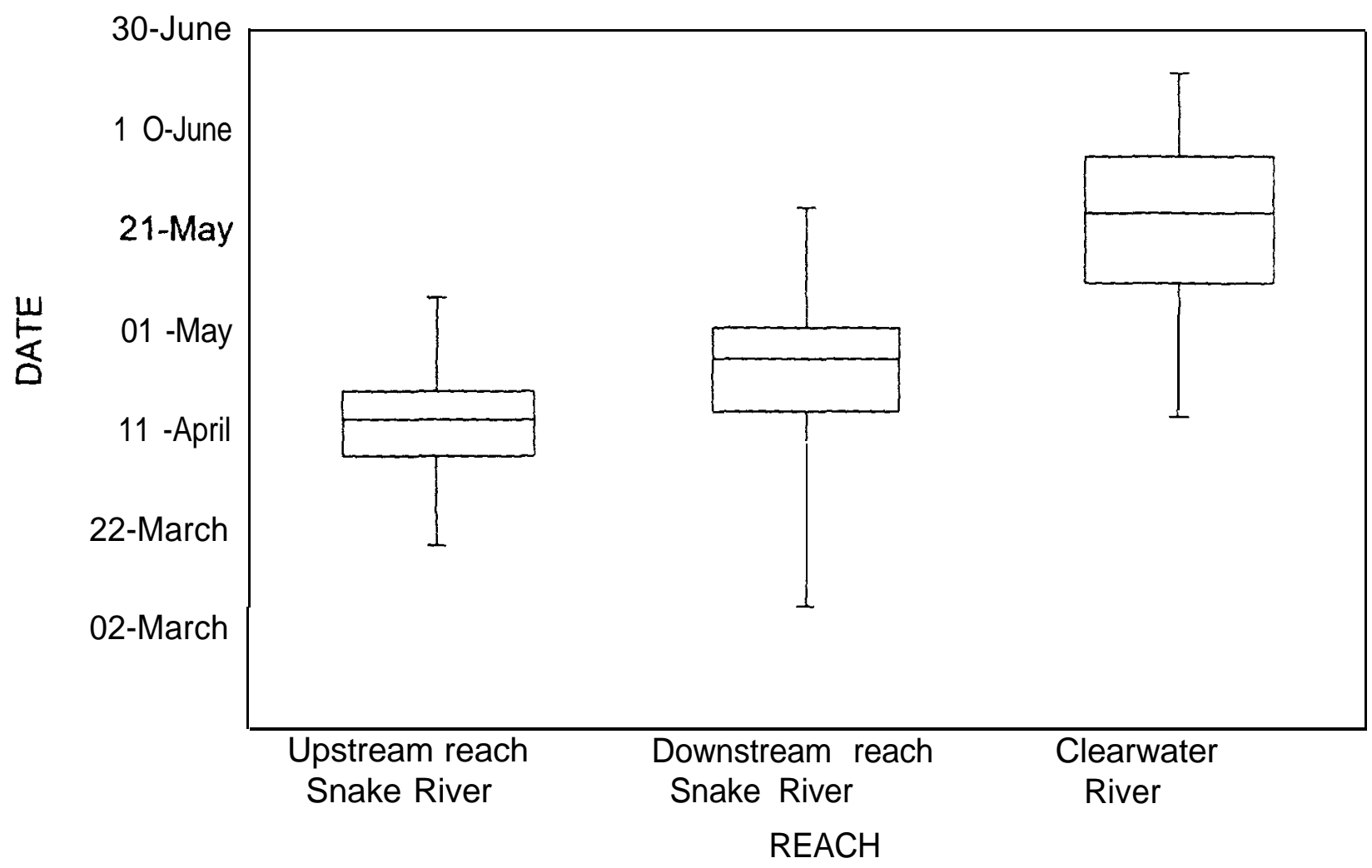

Figure 2.-Calculated emergence dates for fall chinook salmon fry beach seined in the upstream and downstream reaches of Snake River and in the Clearwater River, 1995. The top and bottom of each box are the 25th and 75th percentiles and the horizontal line in the box is the median. The vertical lines show the range. 


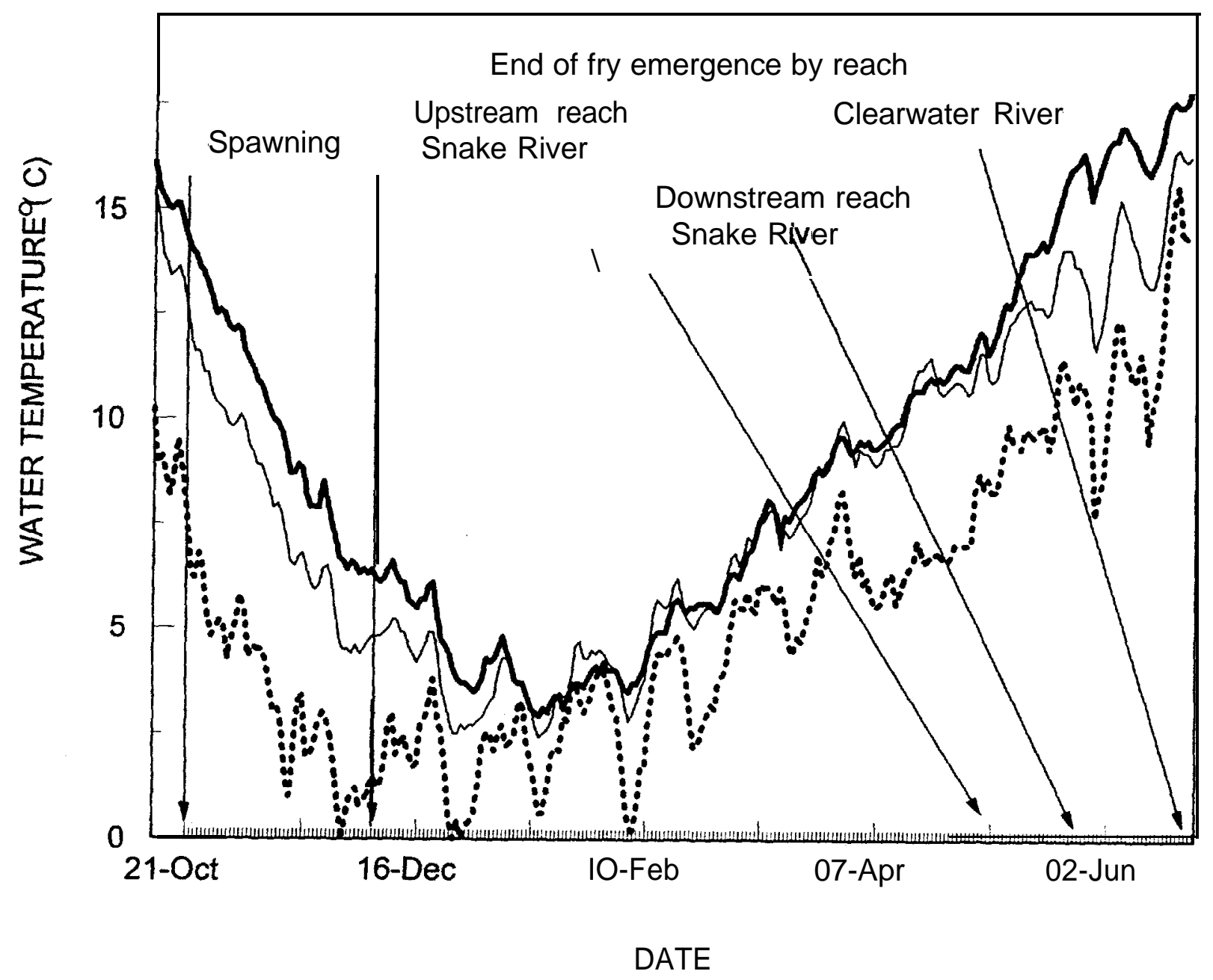

Figure 3.-Mean daily water temperatures in the upstream reach of the Snake River $\left(\right.$,downstream reach of the Snake River $\left({ }_{-}\right.$, and the Clearwater River (......) recorded throughout fall chinook salmon spawning and egg incubation, 1994-1995. 


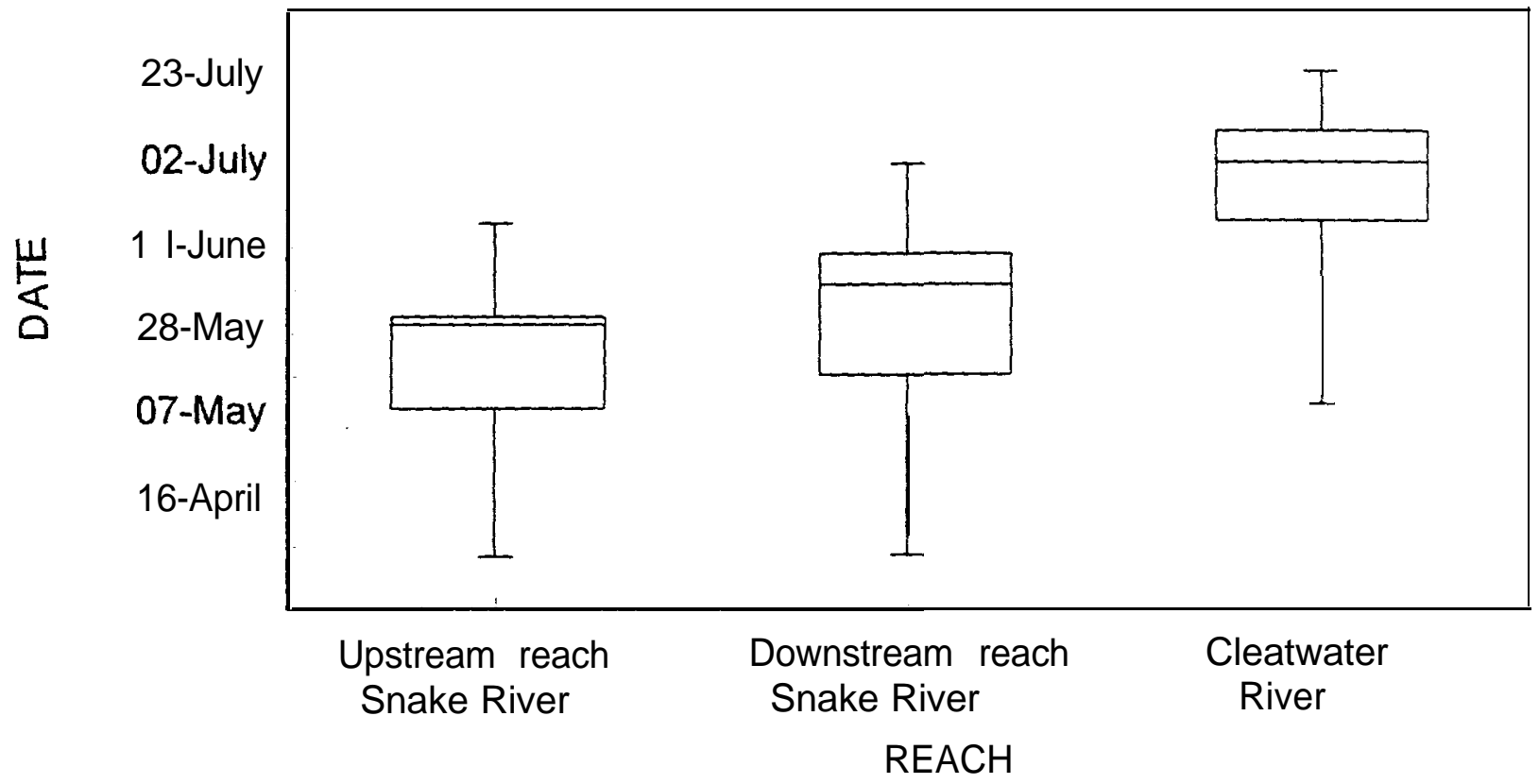

Figure 4.-Capture dates of subyearling fall chinook salmon beach seined in the upstream and downstream reaches of the Snake River, and in the Clearwater River, 1995. The top and bottom of each box are the 25th and 75th percentiles and the horizontal line in each box is the median. The verical lines show the range. 


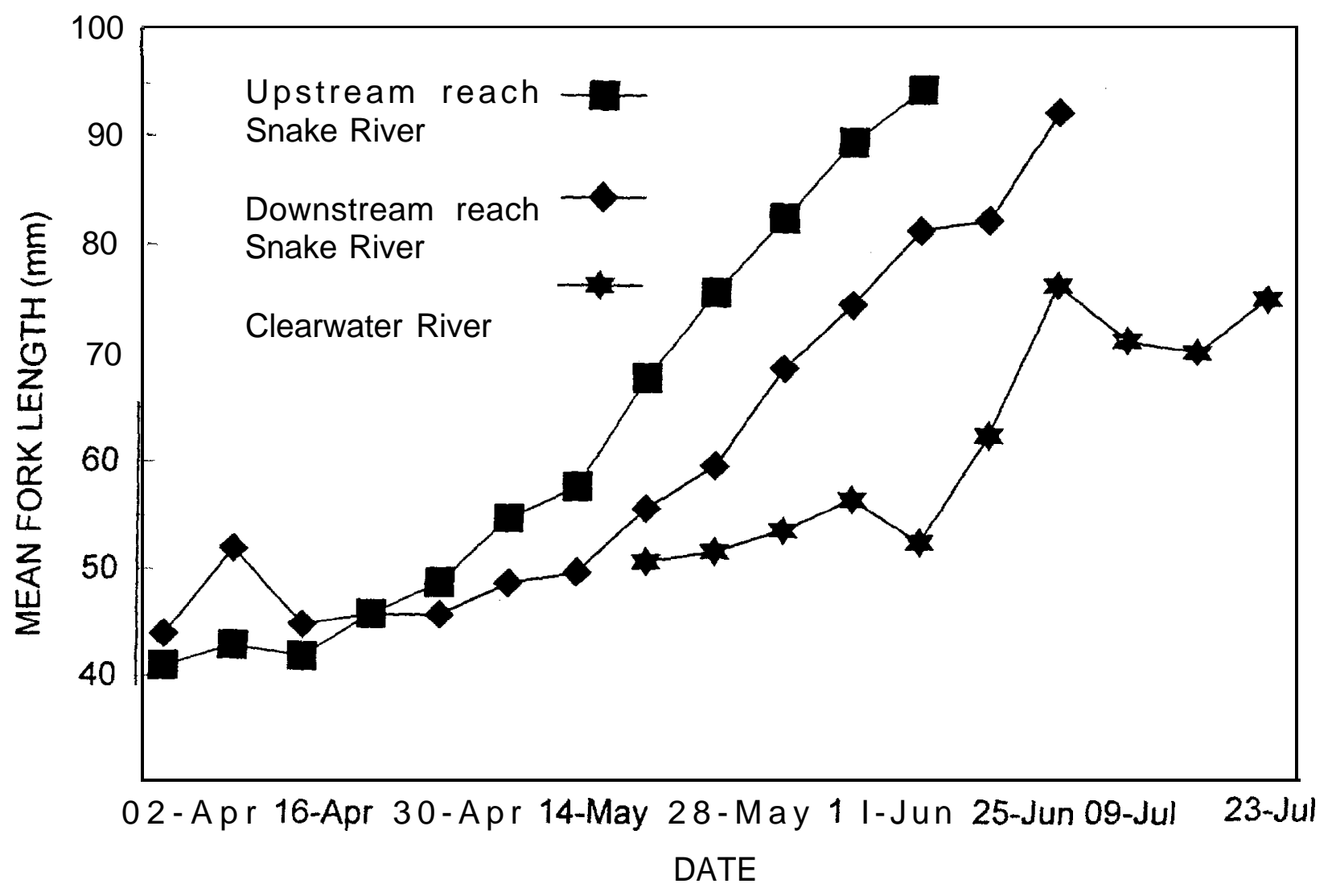

Figure 5.-Mean fork lengths of subyearling fall chinook salmon beach seined in the upstream reach of the Snake River, downstream reach of the Snake River, and the Clearwater River, 1995. 
Table 3.-Number of subyearling fall chinook salmon PIT tagged by week (starting on Sundays) and river reach in 1995.

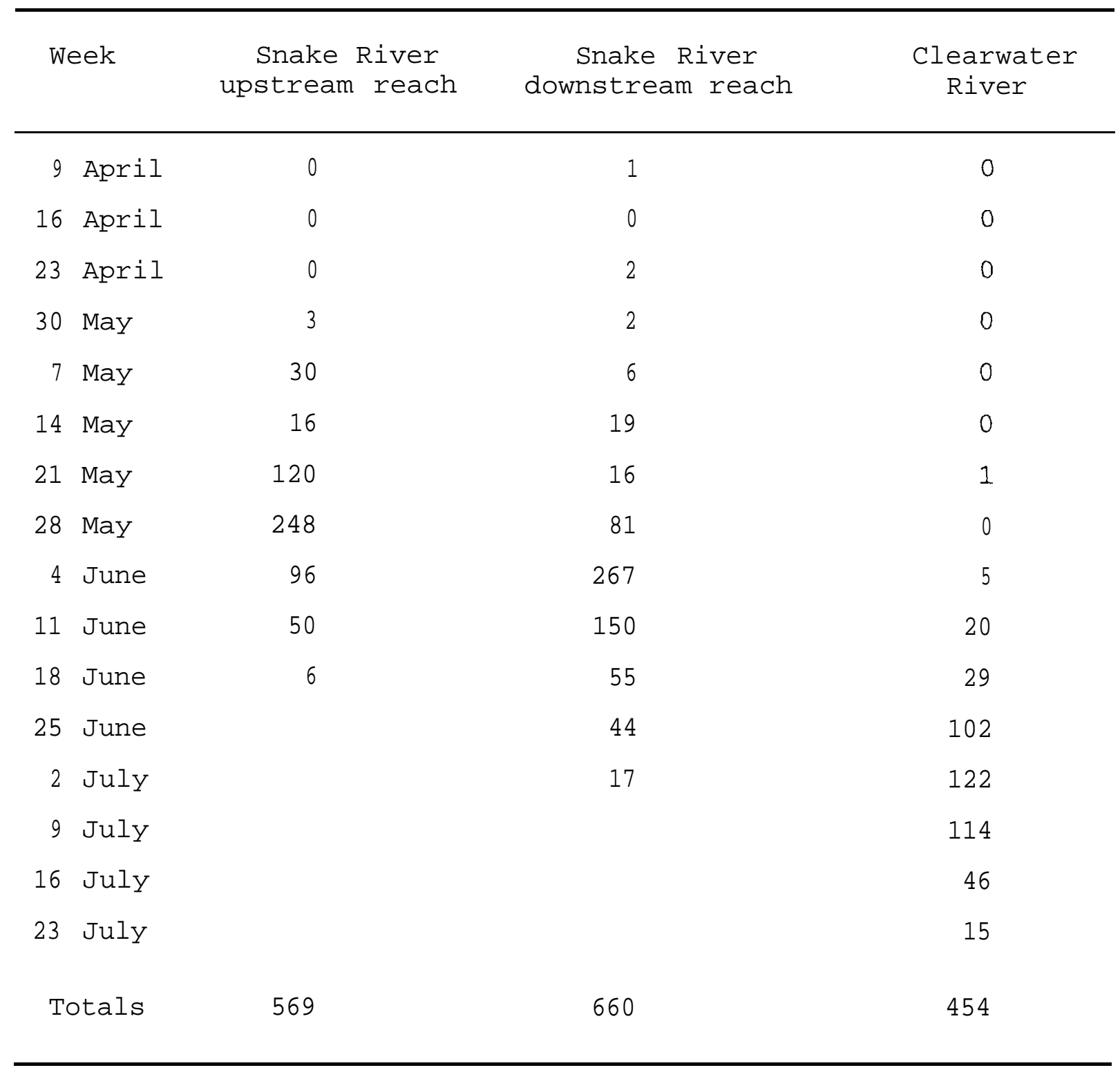


May, 4 June, and 2 July for the upstream and downstream reaches of the Snake River and the Clearwater River.

Fall chinook salmon tagged in 1995 in the upstream reach of the Snake River were detected earlier (median $=26$ July) at lower Snake and Columbia river dams than salmon from the downstream reach of the Snake River (median $=8$ August) and the Clearwater River (median = 13 October; Figure 6). The passage distributions were protracted with detections of PIT-tagged salmon occurring at every dam as fish bypasses were shut down. PIT-tag detections of salmon from the Clearwater River were erratic; occurring in small numbers and days apart. Detections in 1996 of chinook salmon released in 1995 was rare indicating that residualism was low (Table 4). The percentage of residuals was $0.2 \%, 2.1 \%$, and $0.6 \%$ for the upstream reach of the snake River, downstream reach of the Snake River, and the Clearwater River.

\section{Survival}

We documented differences in capture and survival probabilities between fall chinook salmon PIT-tagged in the Snake and Clearwater rivers (Table 5). Salmon tagged in the upstream reach of the Snake River had the highest capture and survival probabilities at Lower Granite Dam followed by fish tagged in the downstream reach of the Snake River then fish tagged in the Clearwater River. Survival probability increased as capture probability increased. Survival estimates for salmon emigrating from the Clearwater River to the tailrace of Lower Granite Reservoir in the summer of 1995 was about $1 / 4(0.175)$ of the survival estimates for upstream reach (0.676) and downstream reach (0.660) Snake River fish (Table 5). Capture probability for fish tagged in the Snake River was only 1.1 to 1.4 times that of fish released in the Clearwater River.

\section{Discussion}

\section{Survival Assumptions}

We made survival estimates for subyearling fall chinook salmon assuming that winter passage by the dams occurs, but is rare. Floods occurred in the snake and Clearwater rivers in the fall of 1995 and some fish that were in the reservoirs moved downstream past Ice Harbor Dam. Samples of fish collected from the gatewells at Ice Harbor Dam on 13 and 15 December included 188 unmarked natural chinook salmon, 54 PIT-tagged hatchery fall 


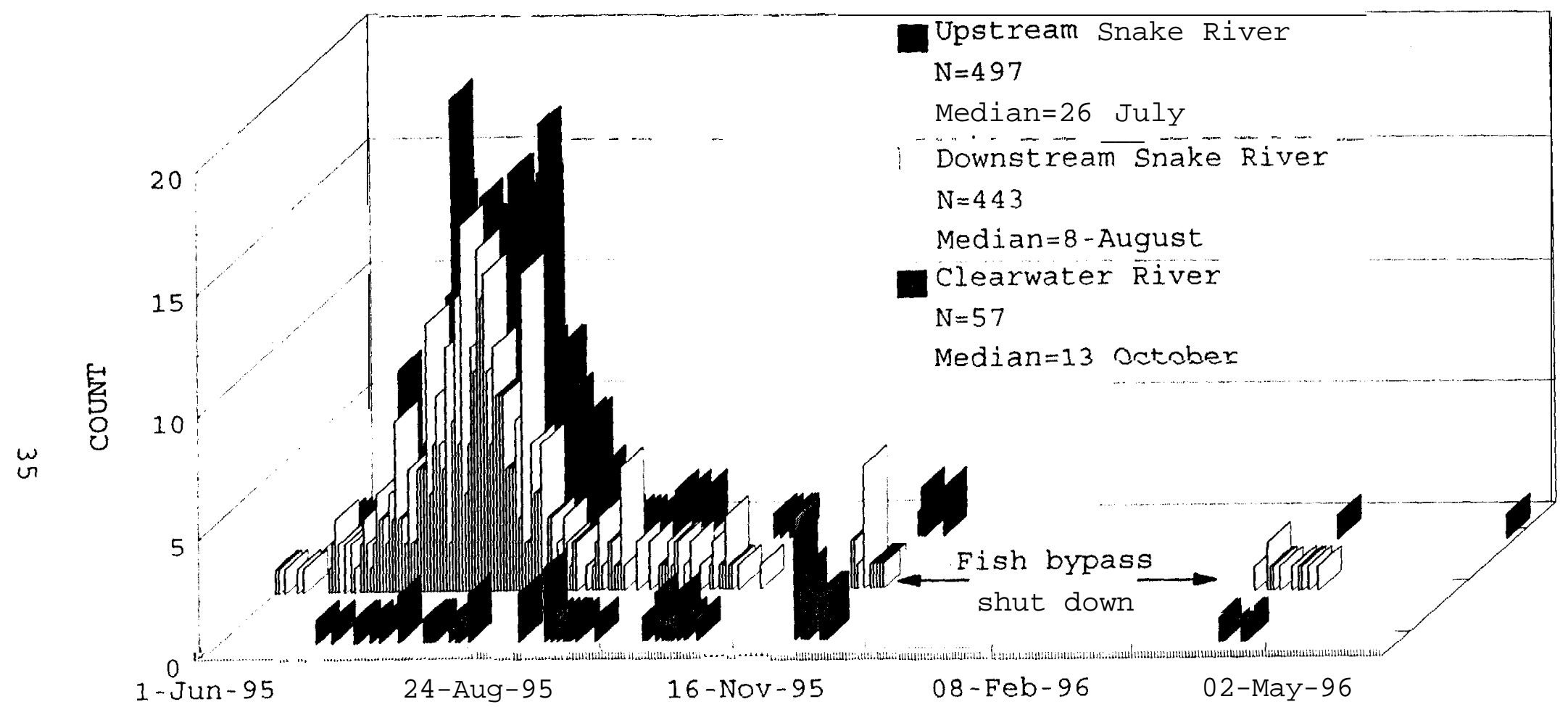

DATE

Figure 6.-Cumulative detections of PIT-tagged subyearling and yearling chinook salmon from the upstream and downstream reaches of the Snake River and the Clearwater River in 1995. Detections occurred at Lower Granite, Little Goose, Lower Monumental, and McNary dams. Detections at each dam are unique, but salmon were detected and counted at more than one dam. 
Table 4 .-Detections of possible fall chinook salmon that were PIT tagged in the Snake or Clearwater rivers in 1995, but were detected as yearlings in 1996 at, or downstream from, Lower Granite Dam.

\begin{tabular}{lccc}
$\begin{array}{c}\text { Release } \\
\text { site }\end{array}$ & $\begin{array}{c}\text { Number } \\
\text { released }\end{array}$ & $\begin{array}{c}\text { Number } \\
\text { detected }\end{array}$ & $\begin{array}{c}\text { Percent } \\
\text { detected }\end{array}$ \\
\hline Snake River upstream & 569 & 1 & $0.2 \%$ \\
Snake River downstream & 660 & 14 & $2.1 \%$ \\
Clearwater River & 454 & 3 & $0.6 \%$ \\
\hline
\end{tabular}

Table 5 .-Capture and survival probability estimates by release site and date for subyearling natural fall chinook salmon released in upstream and downstream reaches of the Snake River and the Clearwater River, 1995. Dates of release are Sundays of the median week of tagging.

\begin{tabular}{cccccc}
\hline \multicolumn{1}{c}{ Release } & & & \multicolumn{2}{c}{$\begin{array}{c}\text { Probability estimates to } \\
\text { tailrace of Lower Granite Dam }\end{array}$} \\
\cline { 1 - 2 } \cline { 5 - 6 } Site & Date & & Capture(S.E.) Survival(S.E.) \\
Snake River upstream & 28 May & $0.523(0.043)$ & $0.676(0.050)$ \\
Snake River downstream & 04 June & $0.434(0.052)$ & $0.660(0.072)$ \\
Clearwater River & 02 July & $0.377(0.117)$ & $0.175(0.060)$ \\
\hline
\end{tabular}


chinook salmon subyearlings, and 3 PIT-tagged natural Snake River fall chinook salmon. No PIT-tagged subyearlings from 1995 Clearwater River releases were collected at Ice Harbor Dam. Winter movements past the dams is an unlikely primary emigration strategy based on biology and logistics. Chapman and Bjornn (1969) found that juvenile chinook salmon in Idaho emigrated downstream in fall then entered spaces between rocks in winter. Undetected winter passage would require tagged salmon to remain in Lower Granite Reservoir until the fish collection system at Lower Granite Dam was shut down in November, and passage by five downstream dams before collection systems were re-opened in early April. Shutdown of fish bypass facilities at the above dams, from late fall to early April, precludes conclusive analyses of winter passage.

\section{Survival Related to Fish Guidance Efficiency and Early Life History}

Snake River fall chinook salmon survival probabilities from the time of PIT tagging to passage by Lower Granite Dam in 1995 were about four times higher than those of Clearwater River fall chinook salmon. Some of the difference in survival between fish in the snake and Clearwater rivers was caused by differences in capture probability. Capture probability is an estimate of the percentage of fish entering the penstock which are routed around the turbine. We estimated that 43\% of fish PIT-tagged in the upstream reach of the Snake River and 52\% of fish tagged in the downstream reach were guided around the turbines compared to 37\% guidance for PIT-tagged Clearwater River fish. The above difference in guidance may be due to the smaller size of Clearwater River migrants or differences in emigration timing. Raymond (1979) reported that salmon which pass through the turbines die at rates of $11 \%$ to $33 \%$. Part, but not all of the four-fold difference in survival estimates to Lower Granite Dam's tail race can be attributed to lower guidance around turbines and the resulting turbine-induced mortality.

Differences in survival between PIT-tagged subyearling fall chinook salmon released in the snake and Clearwater rivers in 1995 was mostly related to the effects of water temperature on early life history timing. Snake River water temperatures were warmer than Clearwater River temperatures. Spawning occurred over a similar period of time in both rivers, but salmon embryos developed faster in the Snake River and emerged, reared, and began seaward migration earlier in the summer. Earlier migrating Snake River fall chinook salmon passed through Lower Granite Reservoir under higher flows than Clearwater River fish and were exposed for shorter durations to warm summer water temperatures. 
Hatchery subyearling fall chinook salmon that were released early and emigrated under high flows survived better than fish which were released later and emigrated under lower flows (Smith et al. in press). Natural subyearling chinook salmon PIT tagged from 1991-1995 were detected at higher rates at Lower Granite Dam when temperatures in Lower Granite Reservoir were cool (Connor et al. in preparation). Detection rates at Lower Granite Dam from 19911995 are relative indices of survival for salmon that migrate seaward in the summer. Early emergence, rearing, and seaward migration positively affected subyearling fall chinook salmon survival.

\section{Management Implications}

Application of our 1995 research to management issues depends upon the existence of consistent differences in early life history between fish in the snake and Clearwater rivers. Differences exist in emergence dates of fry in the snake and Clearwater rivers (Figure 7). We estimated mean dates of emergence for pre-dam historic populations of fall chinook salmon in the Marsing reach of the Snake River and the lower $60 \mathrm{~km}$ of Clearwater River of 23 April $( \pm 7$ d) and 4 June $( \pm 13$ d) based on water temperature. In the more recent period (1976-1981), Snake River water temperatures in the downstream reach were cooler than near Marsing and emergence was later (7 May $\pm 9 d$ ). Dworshak Dam advanced emergence in the Clearwater River (26 May 3 d), but the emergence estimate for the lower reach of the Snake River was still 19 d earlier consistent with 1995 results (Figure 2). Our 1995 results should hold true in the future unless time of spawning advances markedly in the Clearwater River

The goal of the ESA is to restore viable self-perpetuating populations of mammals, birds, and fishes into their native habitat (USFWS 1988). Summer flow augmentation (NMFS 1995) and supplementation with hatchery fish (Miller et al. 1990; Steward and Bjorn 1990) are two tools being used to recover Snake River fall chinook salmon. Most juvenile fall chinook salmon migrate downstream through the lower snake River from 21 June to 31 August and that period has been proposed for flow and temperature modification (NMFS 1995). A target flow of 50,000-55,000 $\mathrm{ft}^{3} / \mathrm{s}$ at Lower Granite Dam has been proposed to lessen travel times for migrating salmon (FPC 1994), and a temperature target of $15^{\circ} \mathrm{C}$ to $17^{\circ} \mathrm{C}$ to increase subyearling fall chinook salmon survival.

Releases of cold water from Dworshak Reservoir for summer flow augmentation may affect growth and time of migration of Clearwater River fall chinook salmon. Flow augmentation in 1994 


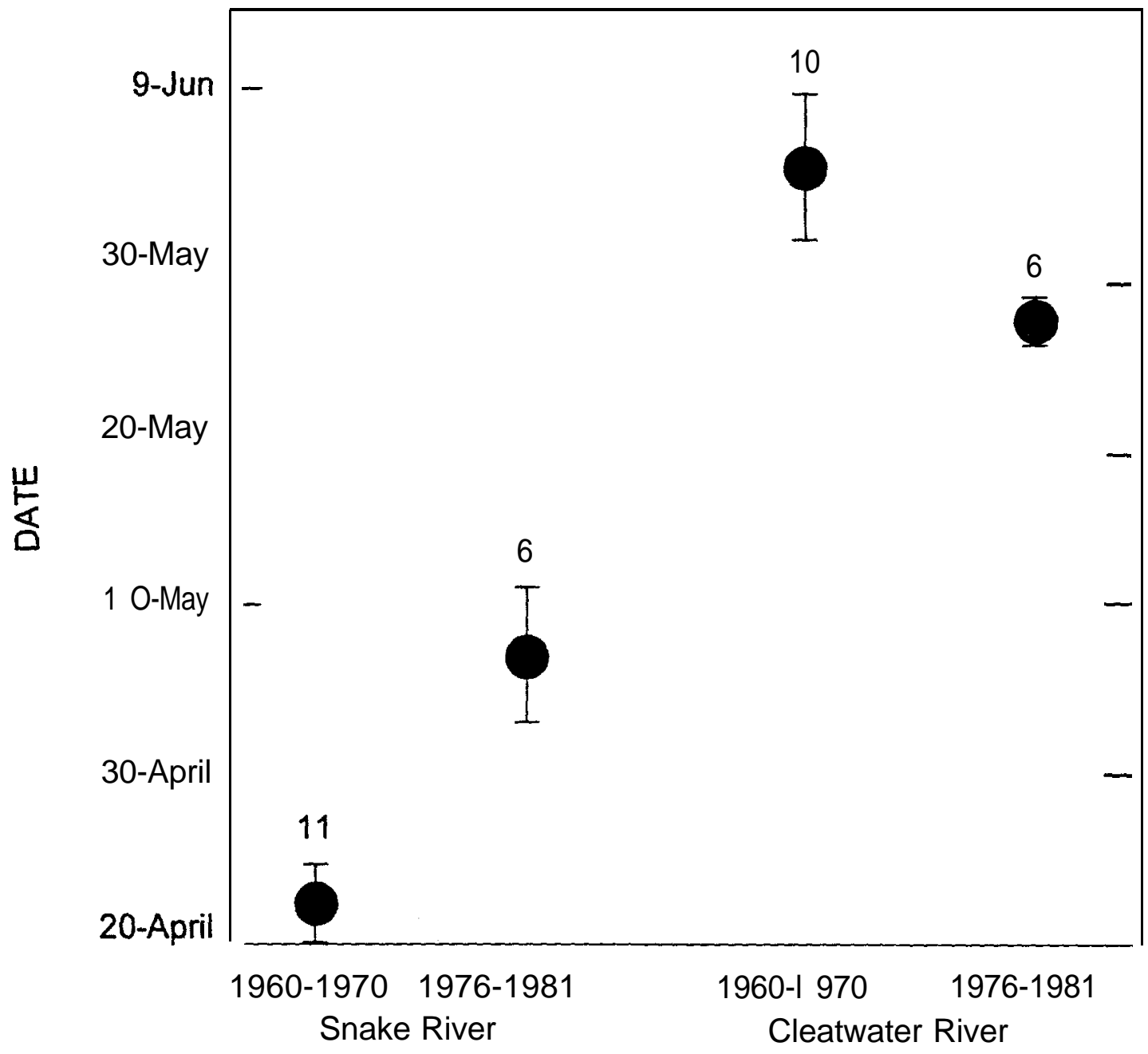

Figure 7.-Mean emergence dates $( \pm S D)$ of fall chinook salmon fry estimated using data collected for pre- and post-dam periods. Snake River data were collected upstream of Brownlee Dam (1960-I 970; representative of pre-dam conditions) and downstream of Hells Canyon Dam at Anatone, Washington (1976-I 980; termed post-dam). Clear-water River data were collected at Spalding Idaho before (1960-I 970) and after (1976-I 981) construction of Dworshak Dam. Number of years used to estimate mean emergence dates is given above SD bars. 
included 26 d of releases of $8.7^{\circ} \mathrm{C}$ water that dropped water temperature in nearshore areas of the Clearwater River from about $16^{\circ} \mathrm{C}$ to $12^{\circ} \mathrm{C}$ when parr were present. Researchers agree that such a drop could possibly affect smoltification (Arnsberg and Statler 1996; Connor et al. 1996). Fish managers shaped flow augmentation from Dworshak Reservoir in 1995 to minimize impacts on subyearling fall chinook salmon rearing in the clearwater River. Protracted high natural flows allowed the delay of flow augmentation from Dworshak Reservoir until $16 \mathrm{July}$, when the releases of $13.0 \mathrm{kcfs}$ of $10^{\circ} \mathrm{C}$ water began and continued for $48 \mathrm{~d}$. Clearwater River fall chinook salmon began emigrating before 16 July (Tables 2 and 3). Prior to $16 \mathrm{July}, \mathrm{Clearwater}$ River temperatures were above $18^{\circ} \mathrm{C}$ and decreased to $15^{\circ} \mathrm{C}-17^{\circ} \mathrm{C}$ after 16 July (Figure 8 ). This decrease put temperatures in a better range for growth (Connor 1989). Summer flow augmentation from Dworshak Reservoir benefited fall chinook salmon in both the Snake and Clearwater rivers in 1995.

The second fall chinook salmon recovery measure is supplementation, or stocking hatchery fall chinook salmon in the Snake and Clearwater rivers to eventually increase the abundance of naturally produced fish. An average of about 250,000 subyearling fall chinook salmon were released in the Snake River each year from 1978-1985 (Roseberg et al. 1992). Adult counts at Lower Granite Dam from 1981-1989, when adults that had spent three years at sea would have returned, ranged from 340 to 951

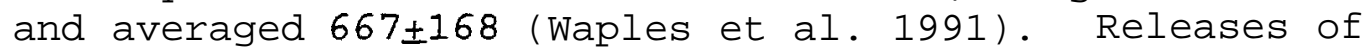
subyearling hatchery fall chinook salmon were discontinued after 1985. Adult escapements after 1990 have been made up of naturally produced fall chinook salmon and fish that stray from downstream hatcheries. After factoring out hatchery strays, an average of $419 \pm 223$ natural adults have passed Lower Granite Dam between 1990 and 1994 (248 less than the 1981-1989 average; Lavoy 1995). Benefits of supplementation in the Snake River appear to have been ephemeral.

Supplementation by Idaho Department of Fish and Game included planting eyed fall chinook salmon eggs in Clearwater River tributaries above the North Fork confluence from 1948-1967 (Waples et al. 1991). According to Waples et al. (1991), egg transfers ranged from 400,000 to 1.6 million from 1960 through 1967. Escapement above Lewiston Dam from 1963-1972 ranged from 5 to 122 fish (mean=52 \pm 41 ; Irving and Bjornn 1981). Fall chinook salmon supplementation in the Clearwater River was discontinued in 1968 before Lower Monumental (1969), Little Goose (1970), and Lower Granite (1975) dams were constructed. Perhaps embryo development in tributaries was slow because of cold water leading to smolt survival even lower than we documented for salmon produced in the lower mainstem Clearwater River in 1995. 


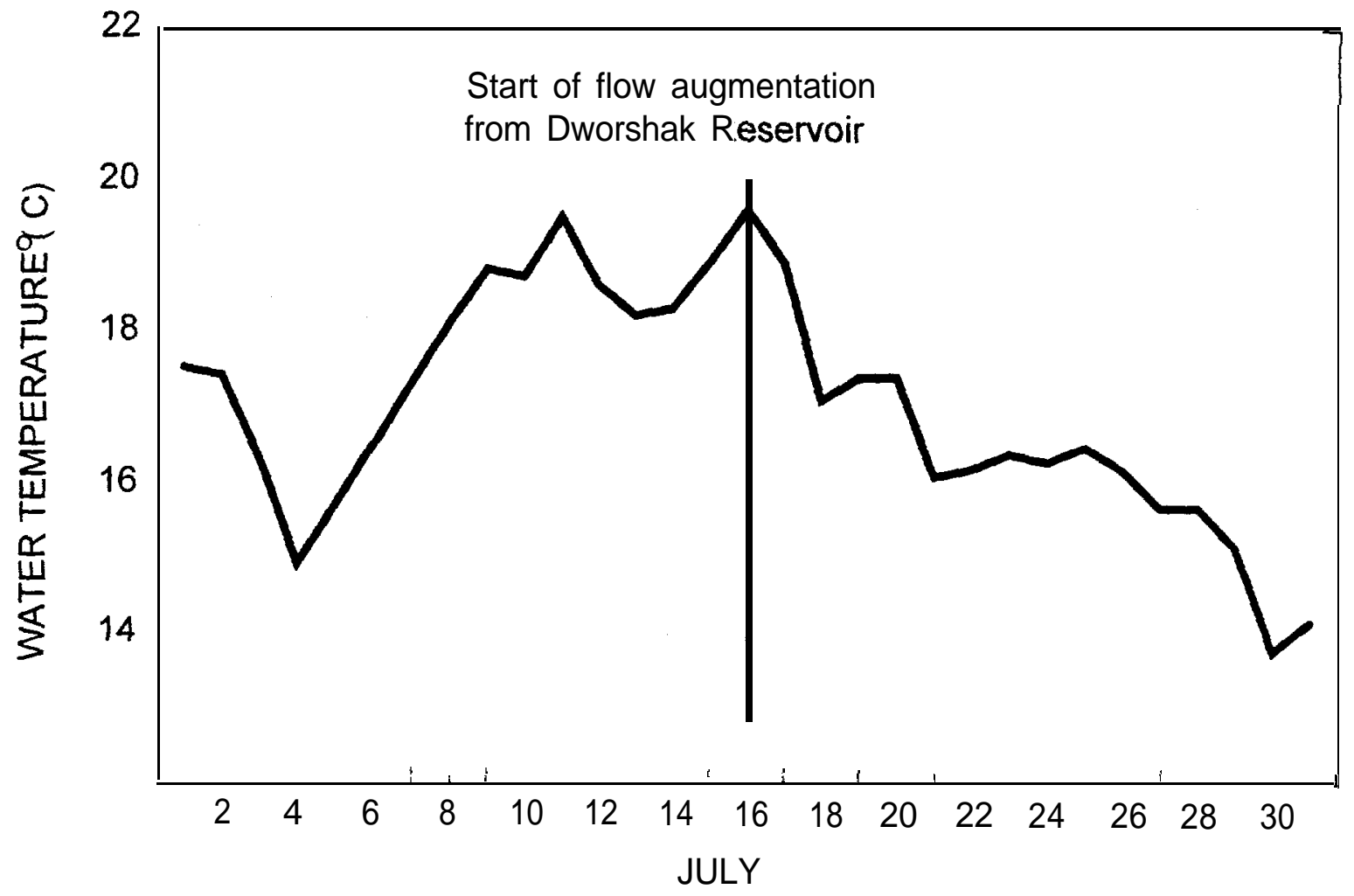

Figure 8.-Mean daily water temperature measured in the Clearwater River by the United States Geological Survey at Spalding, Idaho, July 1995. Flow augmentation began on 16 July in 1995. 
Lack of long-term benefits of past supplementation efforts in the Snake and Clearwater rivers emphasizes the importance of viewing supplementation as an interim recovery measure (Bevan et al. 1994). Based on our studies in 1995, and review of past history, fall chinook salmon production upstream of Lower Granite Dam is constrained by water temperatures. River conditions upstream from Lower Granite Dam do not allow the salmon to grow, become smolts and migrate seaward on the same time schedule as their forbearers. Survival of seaward migrating fall chinook salmon smolts appears to be related to migration timing; late emigrants survive at low rates. Of the three reaches we studied, supplementation with hatchery fall chinook salmon in the upstream reach of the snake River would result in the earliest migrating smolts. Supplementation in the Clearwater River would produce the latest migrating smolts. The main effect of supplementation, regardless of the river stocked, would be artificial inflation of spawner numbers. The evolutionary benefits of maintaining spawning in the wild, and the ability of salmon to adapt and develop successful life history strategies, are unknown. 


\section{References}

Abbersold, T.D., G.A. Winans, D.J. Tel, G.B. Milner, and F.N. Utter. 1987. Manual for starch gel electrophoresis: A method for the detection of genetic variation. Report No 61. National Marine Fisheries Service, Seattle, Washington.

Arnsberg, B.D. and D.P. Statler. 1996. Assessing summer and fall chinook salmon restoration in the upper Clearwater River and principal tributaries. Annual report by the Nez Perce Tribe Department of Fisheries Resource Management to the Bonneville Power Administration, Contract DE-BI7994BL12873, Portland, Oregon.

Arnsberg, B.D., W.P. Connor, and E. Connor. 1992. Mainstem Clearwater River Study: Assessment for salmonid spawning, incubating, and rearing. Final Report to Bonneville Power Administration, Contract DE-BI79-87BP37474, Portland, Oregon.

Bevan, D. and several co-authors. 1994. Snake River Salmon Recovery Team: Final Recommendations to the National Marine Fisheries Service.

Burnham, K.P., D.R. Anderson, G.C. White, C. Brownie, K.H. Pollock. 1987. Design and analysis methods for fish survival experiments based on release-recapture. American Fisheries Society Monograph 5, ISSN 0362-1715, Bethesda, Maryland.

Chapman, D.W. and T.C. Bjornn. 1969. Distribution of salmonids in streams, with special reference to food and feeding. Pages 153-176 in T.G. Northcote, editor. Symposium on salmon and trout streams. University of British Columbia, Vancouver.

Connor, W.P. 1989. Mainstem Clearwater River Study: Assessment for salmonid spawning, incubation, and rearing. Annual progress report by the Nez Perce Tribe Department of Fisheries Resource Management, Contract no. DE-AI79-87BP37474, to Bonneville Power Administration, Portland, Oregon.

Connor, W.P., H.L. Burge, R.D. Nelle, C. Eaton, and R. Waitt. 1996. Rearing and emigration of naturally produced Snake River fall chinook salmon juveniles. Pages 49-73 in D. Rondorf and $\mathrm{K}$. Tiffan, editors. Identification of the spawning, rearing, and migratory requirements of fall 
chinook salmon in the Columbia River Basin. Annual Progress Report by the United States Fish and Wildlife Service, Contract DE-AI79-91BP21708, to Bonneville Power Administration, Portland, Oregon.

Connor, W.P., H.L Burge, S.G. Smith, D.W. Rondorf, and K.F. Tiffan. In press. Post Release Attributes and Survival of Natural and Hatchery Subyearling Fall Chinook Salmon Released in the Snake River. Chapter 2 in J.G. Williams, R.N. Iwamoto, and T.C. Bjornn, editors. Fall Chinook Salmon Survival and Supplementation Studies in the Snake River and Lower Snake River Reservoirs. Annual Progress Report by the National Marine Fisheries Service, United States Fish and Wildlife Service, and National Biological Service. Contract E86950141 with the U.S. Army Corps of Engineers, Walla Walla, Washington and Contract DE-AI79-91BP21708 with the Bonneville Power Administration Portland, Oregon.

Connor, W.P., and several co-authors. In preparation. Effects of water temperature and flow on detection rates of PITtagged Snake River Subyearling chinook salmon.

Cormack, R. M-1964. Estimates of survival from the sightings of marked animals. Biometrika 51:429-438.

FPC (Fish Passage Center of the Columbia Basin Fish and Wildlife Authority). 1994. 1993 Annual Report. Portland, Oregon.

Haas, J.B. 1965. Fishery problems associated with Brownlee, oxbow, and Hells Canyon Dams on the middle Snake River. Fish Commission of Oregon, Investigational Report Number 4, Portland.

Healy, M.C. 1991. Life history of chinook salmon (Oncorhynchus tshawytscha). Pages 313-393 in C. Groot and L. Margolis, editors. Pacific Salmon Life Histories. UBC press, University of British Columbia, Vancouver.

Irving, J.S. and T.C. Bjornn. 1981. Status of Snake River fall chinook salmon in relation to the Endangered Species Act. Prepared for the U.S. Fish and Wildlife Service, Portland, Oregon.

Iwamoto, R. N., W. D. Muir, B. P. Sandford, K. W. McIntyre, D. A. Frost, and J.G. Williams. 1994. Survival estimates for the passage of juvenile salmonids through dams and reservoirs. Annual report by the National Marine Fisheries 
Service to the Bonneville Power Administration, Contract DE-AI79-93BP10891, Portland, Oregon.

Jolly, G. M. 1965. Explicit estimates from capture-recapturel data with both death and immigration - stochastic model. Biometrika $52: 225-247$.

Lavoy, 1. 1995. Stock composition of fall chinook salmon at Lower Granite Dam in 1994. Washington Department of Fish and Wildlife, Anadromous Fish Division - Columbia River, Progress Report 95-6, Battle Ground.

Miller, W.H., T.C. Coley, H.L. Burge, and T.T. Kisanuki. 1990. Analysis of Salmon and Steelhead Supplementation: Emphasis on Unpublished Reports and Present Programs. Pages 1-46 in W.H. Miller editor. Analysis of salmon and steelhead supplementation. A final report by the United States Fish and Wildlife Service to the Bonneville Power Administration, Contract No. DE-A179-88BP92663. Portland, Oregon.

NMFS (National Marine Fisheries Service). 1992. Threatened status for Snake River spring/summer chinook salmon, threatened status for Snake River fall chinook salmon. Final rule, April 22, 1992. Federal Register, Vol. 57, No. 78.

NMFS (National Marine Fisheries Service). 1995. Proposed recovery plan for Snake River Salmon. U.S. Department of Commerce, National Oceanographic and Atmospheric Administration. Portland, Oregon.

Piper, R.G., I.B. McElwain, L.E. Orme, J.P. McCraren, L.G. Fowler and J.R. Leonard. 1982. Fish Hatchery Management. United States Department of the Interior, Fish and Wildlife Service, Washington, D.C.

Prentice, E.F., T.A. Flagg, and C.S. McCutcheon. 1990. Feasibility of using implantable passive integrated transponders (PIT) tags in salmonids. American Fisheries Society Symposium 7:317-322.

Raymond, H.L. 1979. Effects of dams and impoundments on migrations of juvenile chinook salmon and steelhead from the Snake River, 1966 to 1975. Transactions of the American Fisheries Society 108:505-529.

Roseberg, R., H. Burge, W. Miller, and D. Diggs. 1992. A review of coded-wire tagged fish released from Dworshak, Kooskia, and Hagerman National Fish Hatcheries, 1976-1990. 
United States Fish and Wildlife Service, Idaho Fishery Resource Office, Ahsahka, Idaho.

Schoning, R.W. 1947. Snake River fall report. Oregon Department of Fisheries. LaGrande, Oregon.

Schoning, R.W. 1940. Report on the Snake River Basin including the Umatilla River. Oregon Department of Fisheries.

LaGrande, Oregon.

Seber, G. A. F. 1965. A note on the multiple recapture census. Biometrika 52:249-259.

Smith, S. G., J. R. Skalski, J. W. Schlechte, A. Hoffmann, and V. Cassen. 1994. Statistical Survival Analysis of Fish and Wildlife Tagging Studies. SURPH.1 Manual. Center for Quantitative Science, Box 355230, University of Washington, Seattle, WA 98195.

Smith, S.G., W.D. Muir, E.E. Hockersmith, and W.P. Connor. In press. Passage Survival of Natural and Hatchery Subyearling Fall Chinook Salmon to Lower Granite, Little Goose, and Lower Monumental Dams. Chapter 1 in J.G. Williams, R.N. Iwamoto, and T.C. Bjornn, editors. Fall Chinook Salmon Survival and Supplementation Studies in the Snake River and Lower Snake River Reservoirs. Annual Progress Report by the National Marine Fisheries Service, United States Fish and Wildlife Service, and National Biological Service. Contract E86950141 with the U.S. Army Corps of Engineers, Walla Walla. Washington and Contract DE-AI79-91BP21708 with the Bonneville Power Administration Portland, Oregon.

Steward, C.R., and T.C. Bjornn. 1990. Supplementation of salmon and steelhead stocks with hatchery fish: A synthesis of published literature. Pages 1-126 in W.H. Miller editor. Analysis of salmon and steelhead supplementation. A final report by the University of Idaho to the Bonneville Power Administration, Contract No. DE-A179-88BP92663. Portland, Oregon.

SYSTAT. 1994. SYSTAT for Windows, Base 5.0. SYSTAT Inc., Evanston Illinois.

USFWS (United States Fish and Wildlife Service), 1988. Endangered Species Act of 1973 as amended through the 100th Congress. United States Department of the Interior, Washington, D.C. 
Waples, R.S., R.P. Jones, B.R. Beckman, and G.A. Swan. 1991. Status review for Snake River fall chinook salmon. United States Department of Commerce, National Oceanographic and Atmospheric Administration Technical Memorandum NMFS F/NWC201. Portland, Oregon. 


\section{CHAPTER THREE}

Behavior of Juvenile Fall Chinook Salmon in the Forebay of a Lower Snake River Reservoir

by

D.A. Venditti, J.M. Kraut, and D.W. Rondorf United States Geological Survey Biological Resources Division Columbia River Research Laboratory Cook, WA 98605, USA 


\section{Introduction}

The effect of hydroelectric development in the snake and Columbia river basins on the migratory behavior of juvenile salmonids is of particular concern because these dams are known to delay the timing and migration rates of outmigrating juvenile salmonids (Oncorbynchus spp.; Raymond 1969; Netboy 1973; Raymond 1979). Past studies have used the mark and recapture of freeze branded fish (Raymond 1968; Bentley and Raymond 1976; Berggren and Filardo 1993) or passive integrated transponder (PIT; Prentice et al. 1990) tagged fish (Connor et al. 1993; Connor et al. 1994; Achord et al. 1996) to describe juvenile salmonid passage and migratory behavior. These techniques permit large numbers of individuals to be marked relatively quickly and inexpensively, however, it is impossible to identify specific areas between marking and recapture locations where migrational delays are occurring. Smith et al. (1993) recognized this limitation and recommended, "future research efforts be directed at improving the resolution of travel time estimates by measuring responses through shorter reaches of river."

Passage time through specific reservoir sections can be estimated using radio telemetry, thus allowing investigators to identify areas where smolts spend inordinate amounts of time. In the past, however, transmitters were too large for use with smolt sized animals. The recent miniaturization of radio telemetry equipment now allows researchers to fit salmonid smolts as small as $115 \mathrm{~mm}$ fork length (FL) with radio transmitters. In this study, we used radio telemetry to describe wild, juvenile fall chinook salmon Oncorbynchustshauytschsa passage through Little Goose Reservoir, with particular emphasis on their behavior within the forebay. Our objectives were to: 1) compare residence time and migration rates of juvenile fall chinook salmon through two reservoir reaches and the forebay, and 2) describe juvenile fall chinook salmon behavior while in the Little Goose Dam forebay.

\section{Methods}

Little Goose Reservoir (Lake Bryan), is located on the lower Snake River in eastern Washington (Figure 1). The reservoir was created in 1970 with the completion of Little Goose Dam, and is approximately $60.3 \mathrm{~km}$ long. Little Goose is the third dam on the Snake River upstream of the confluence with the Columbia River, and there is one dam upstream from Little Goose before the freeflowing Hells Canyon reach (Figure 1). 


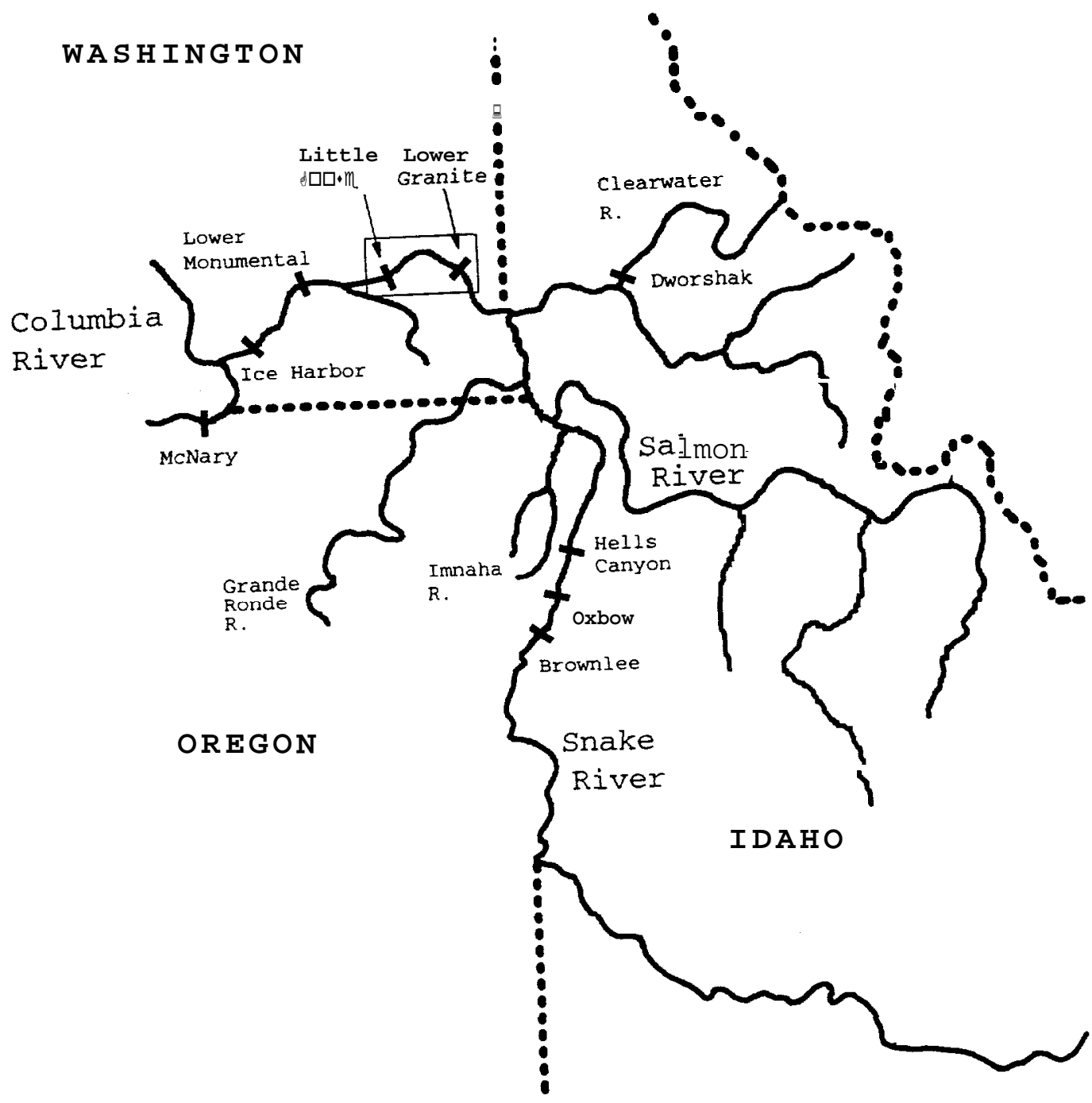

Figure 1.-Location of selected Snake River dams and tributaries. Inset shows location of Little Goose Reservoir. 
Naturally produced juvenile fall chinook salmon were collected and fitted with radio transmitters at the Lower Granite Dam juvenile fish collection facility between 10 July and 1 August 1995. Smolt race and origin (hatchery or wild) were determined by Washington Department of Fish and Wildlife personnel during routine smolt monitoring operations. Fish had to be at least $115 \mathrm{~mm} \mathrm{FL}$ and have no visible signs of injury or stress to be selected for tagging. Fish meeting these criteria were anesthetized in tricaine methanesulfonate (MS-222), measured to the nearest $1 \mathrm{~mm} \mathrm{FL}$ and weighed to the nearest $0.1 \mathrm{~g}$. A radio transmitter with unique frequency was then gastrically implanted in the juvenile fall chinook salmon using the technique described by Snelling (1996). After tagging, fish were allowed to recover in river water for approximately $24 \mathrm{~h}$ before being released. Transmitters were $14.4 \mathrm{~mm}$ long by $7.3 \mathrm{~mm}$ in diameter, weighed $0.99 \mathrm{~g}$ in air and $0.76 \mathrm{~g}$ in water, and had a guaranteed life span of 21 d (Kelly and Adams 1996).

After release, juvenile fall chinook salmon movements were monitored by automated receivers connected to stationary antennas (hereafter referred to as arrays). Related arrays were grouped into banks, generally depending on their location in the study area. Banks were located $14.4 \mathrm{~km}$ above Little Goose Dam at New York Island, on barges in the Little Goose forebay boat restricted zone, and along the face of the dam (Figure 2). Additional banks were located at the Little Goose juvenile fish collection facility and on the shoreline approximately $1 \mathrm{~km}$ below the dam. Banks will be referred to as island, barge, dam and exit. This configuration enabled us to calculate separate residence times and migration rates $(\mathrm{km} / \mathrm{d})$ for fish in the upper 45.9 and lower $14.4 \mathrm{~km}$ of the reservoir, and to estimate the time fish spent in the immediate forebay area before passing the facility. All arrays used temporally synchronized Lotek ${ }^{2} \mathrm{~W}-18$ receivers and one to four directional antennas, which allowed detections from different receivers to be accurately time sequenced. Information was downloaded from these receivers onto a portable personal computer approximately every other day to reduce the extent of data loss if a receiver malfunctioned and to add or remove frequencies as fish passed through the study area.

Receivers in multiple-antenna arrays (barge and dam banks) were configured in a master-slave arrangement. In this system, receivers scanned each programmed frequency for $3 \mathrm{~s}$, receiving

Use of trade names does not imply endorsement by the U.S. Geological Survey or the United States Government. 

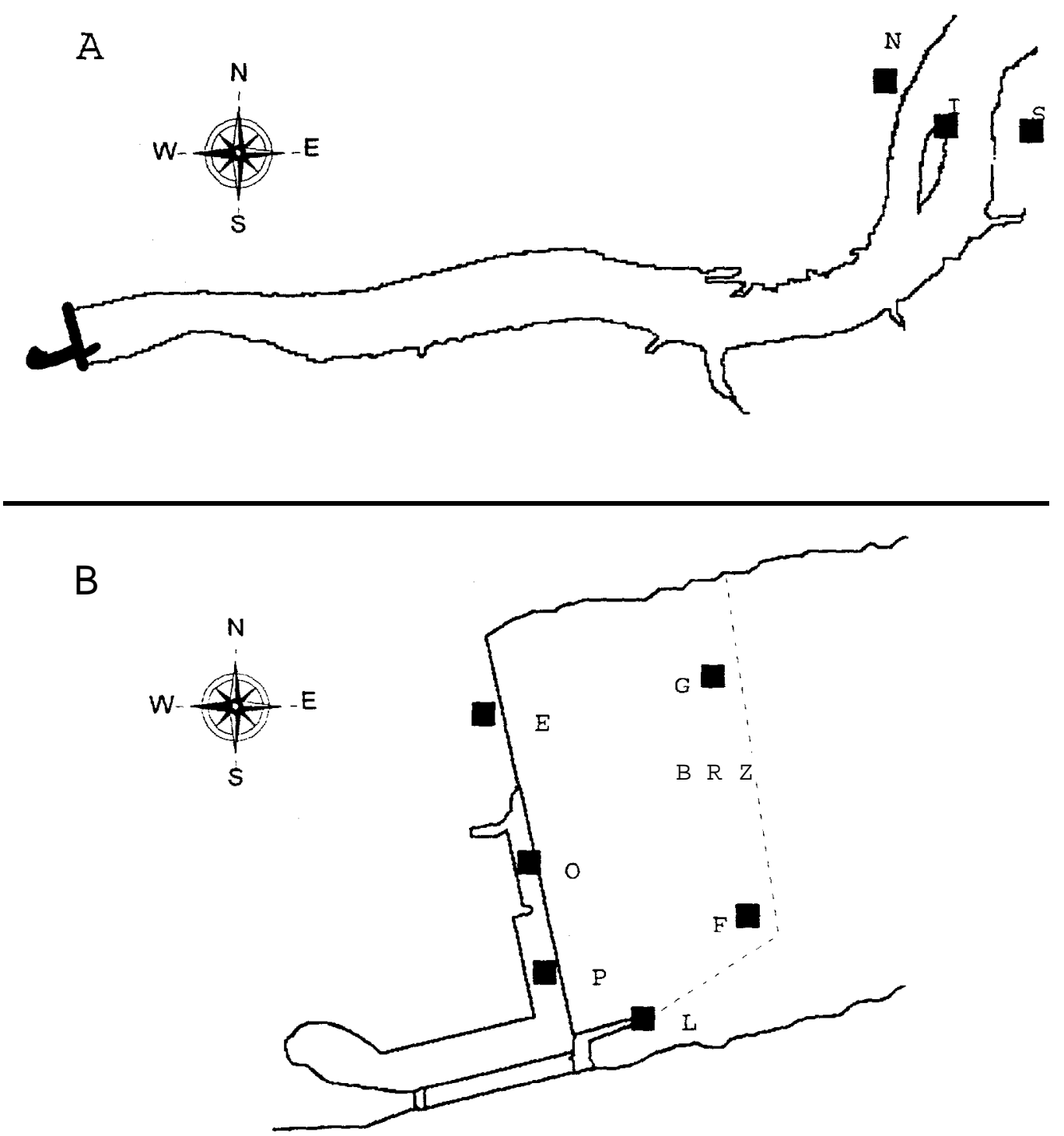

Figure 2. -Locations of fixed arrays of antennas used to monitor the movements of radio-tagged juvenile fall chinook salmon in Little Goose Reservoir during July - August 1995 and 1996. Location of arrays N, I, and $S$ are at New York Island, $14.4 \mathrm{~km}$ upstream of Little Goose Dam (A). Arrays F and G were located on barges in the forebay boat restricted zone (BRZ), and $\mathrm{E}, \mathrm{O}, \mathrm{P}$, and $\mathrm{L}$ were located at the earthen dam, spillway, powerhouse, and navigation lock, respectively (B). 
signals from all antennas (master) simultaneously until a radio signal was detected. The receiver then recorded the date, time, frequency, signal strength, and beats-per-minute of the signal. The receiver then scanned each individual antenna (slave) for an additional $3 \mathrm{~s}$ recording the above information plus the slave antenna number if the signal was again detected. This configuration increased the accuracy and precision of location estimates, because the directional properties of the antennas result in signal strength being highest on the antenna the transmitter is nearest.

Data analysis consisted of arranging all detections for individual frequencies in chronological order creating a sequential record of each fish's location over time. From these records, residence time in the upper reach was calculated as the time from release to the fish's first detection at the island bank. Residence time in the lower reach was the time between initial detections at the island and barge or dam banks. Finally, forebay residence time was the time between initial detections at either the barge or dam bank and the time of first detection at an exit bank or the last detection at a barge or dam bank. Migration rates were calculated as reach length divided by residence time.

Migration rates through the reservoir reaches and forebay residence times were compared between release groups using the nonparametric Kruskal-Wallis test, with significance assumed at $a \leq 0.05$. The nonparametric test was chosen because the data were not normally distributed. Nonparametric tests were also used compare these results to other related studies (ie. Dawley et al. 1986, Fish Passage Center 1994, Muir 1995). To approximate a nonparametric multiple range test to identify release groups with differing migration rates or forebay residence times, the raw data were ranked and a standard analysis of variance was run on the rank scores. This procedure is equivalent to the Kruskal-Wallis test and the "F" statistic calculated by the parametric procedure is often better than the $\chi^{2}$ approximation used in the Kruskal-Wallis test (SAS Institute Inc. 1990). This technique then permits the calculation of a Tukey's multiple comparison test, which is an acceptable approximation when used in this manner (SAS Institute Inc. 1990). When differences in residence times or migration rates were not detected, the data were pooled.

The sequential detection records were also used to determine individual fish locations in the forebay over time, and were separated into "initial" and "subsequent" dam encounters for analysis. An initial dam encounter was defined for fish that had 
not been detected at the dam previously, and were first detected at the barge bank and then detected at the dam within $1 \mathrm{~h}$. Encounters not meeting these criteria were classified as subsequent. An encounter lasted from the time a fish was first detected at a barge or the dam and lasted through the final detection prior to its absence from the telemetry record for $>1$ h. Separate encounter records were created each time a fish entered the forebay record, so multiple encounter records were created for some fish. Encounter records $>2 \mathrm{~h}$ in duration were analyzed for duration and number of forebay crosses (laterally, longitudinally, and diagonally). A $2 \mathrm{~h}$ minimum record length was chosen to maximize the number of fish included in the analysis, while maintaining sufficient record length to accurately describe their behavior. Crosses per hour were then calculated by dividing the total number of crosses by encounter duration. Crosses per hour were compared between initial and subsequent encounters to determine if juvenile fall chinook salmon behavior changes after encountering the Little Goose Dam forebay.

Absences from the forebay telemetry record were considered upstream excursions when the following criteria were met: I) The fish was not detected at the dam or barge banks for $\geq 1 \mathrm{~h}$, and the detections ending and resuming the chronological sequence for that fish were at a barge or the navigation lock. 2) An absence from the forebay record was also considered an upstream excursion if the fish was detected at the island bank after the fish was known to have reached the dam regardless of where the chronological record was broken or resumed. Upstream excursions were analyzed for duration, the number of excursions per individual and whether or not the individual returned to the island bank.

\section{Results}

One hundred nineteen juvenile fall chinook salmon were radio tagged and released into Little Goose Reservoir in six release groups of approximately 20 fish each (Table 1). The mean size of tagged fish increased from $132 \mathrm{~mm} \mathrm{FL}$ and $29.4 \mathrm{~g}$ in the first release to $155 \mathrm{~mm}$ and $53.5 \mathrm{~g}$ in release six (Table 1). Tag retention was $100 \%$, but one tag failed during the 24 -h recovery period. Tagging mortality was $3.2 \%$ ( 4 of 124) over the same period. Three mortalities were from release group three, of which two were approximately 5\% descaled.

Residence times in the upper and lower reservoir reaches were similar, but due to the difference in reach length migration rates differed. Median passage through the reaches occurred in 
Table 1.-Release dates, number, and mean fork length (mm) and weight ( $g$ ) of radio-tagged juvenile fall chinook salmon released into Little Goose Reservoir during July - August 1995 and 1996.

\begin{tabular}{|c|c|c|c|c|c|c|}
\hline $\begin{array}{c}1995 \\
\text { Releases } \\
\end{array}$ & $\begin{array}{l}\text { Release } \\
\text { Date (s) }\end{array}$ & $N$ & Length & h (SD) & Weight & $t \quad(\mathrm{SD})$ \\
\hline 1.00 & $7 / 11$ & 20 & 132 & $(9.53)$ & 29.4 & $(6.01)$ \\
\hline 2.00 & $7 / 14-15$ & 19 & 136 & $(10.87)$ & 34.0 & $(8.15)$ \\
\hline 3.00 & $7 / 19$ & 16 & 133 & $(12.38)$ & 34.8 & $(8.78)$ \\
\hline 4.00 & $7 / 21$ & 20 & 142 & $(8.35)$ & 44.1 & $(8.40)$ \\
\hline 5.00 & $7 / 28,30$ & 21 & 152 & $(6.03)$ & 50.2 & $(6.50)$ \\
\hline 6.00 & $8 / 02$ & 23 & 152 & $(8.40)$ & 52.7 & $(7.24)$ \\
\hline Overall & -- & 119 & 142 & $(12.40)$ & 41.5 & $(11.54)$ \\
\hline \multicolumn{7}{|l|}{$\begin{array}{c}1996 \\
\text { Releases }\end{array}$} \\
\hline 1.00 & $7 / 16$ & 25 & 138 & $(9.3)$ & 33.0 & $(7.4)$ \\
\hline 2.00 & $7 / 19,21$ & 25 & 143 & $(7.4)$ & 39.0 & $(6.1)$ \\
\hline 3.00 & $7 / 23$ & 19 & 144 & $(10.3)$ & 41.3 & $(9.8)$ \\
\hline 4.00 & $7 / 26$ & 20 & 143 & $(9.0)$ & 38.1 & $(6.8)$ \\
\hline 5.00 & $7 / 30$ & 19 & 148 & $(8.5)$ & 42.7 & $(7.7)$ \\
\hline 6.00 & $8 / 02$ & 20 & 147 & $(10.5)$ & 42.5 & $(9.7)$ \\
\hline Overall & -- & 128 & 144 & $(9.5)$ & 39.1 & $18.5)$ \\
\hline
\end{tabular}


$1.8 \mathrm{~d}$ in the upper and $1.0 \mathrm{~d}$ in the lower reach. Migration rates within the reaches did not differ between release groups

(Kruskal-Wallis, $\mathbf{F}=0.89, \quad \mathbf{P}=0.4965$ upper reach, $\mathbf{F}=1.21, \mathbf{P}=$ 0.3226 lower reach), but fish migrated faster through the upper reach than through the lower reach. Median migration rates were 26.0 and $14.9 \mathrm{~km} / \mathrm{d}$ through the upper and lower reservoir reaches, respectively, and differed significantly (Wilcoxon 2-Sample Test, $Z=-3.6721 P=0.0002 ;$ Figure 3 ). Migration statistics for each quartile of juvenile fall chinook salmon passage through the two reservoir reaches are presented in Table 2.

Fish spent less time in the forebay than in either reservoir reach, but due to its short length $(0.6 \mathrm{~km})$ the migration rate through this section was actually the lowest observed. Median forebay residence time was $0.8 \mathrm{~d}$ (range $28 \mathrm{~min}-28.5 \mathrm{~d}$ ), and the median rate of migration through the forebay was $0.7 \mathrm{~km} / \mathrm{d}$ (Table 2; Figure 3). Migration rates through the forebay were variable and differed between release groups (Kruskal-Wallis, F=3.42 P $=0.0073)$. Tukey's Studentized Range Test (performed on rank scores) identified the migration rate of fish from release one (median $0.21 \mathrm{~km} / \mathrm{d}$ ) as being significantly lower than that of release three and six (medians 1.27 and $1.47 \mathrm{~km} / \mathrm{d}$, respectively) despite the general decline in river flow over the study period (Figure 4).

Median residence time in the forebay $(0.8 \mathrm{~d})$ and lower reservoir section $(1.0$ d) was the same as through the upper reach $(1.8$ d) despite being only a third as long. However, all fish passed through the upper reach within $5 \mathrm{~d}$, but $18 \%$ of study fish remained in the forebay and lower reach between 7 and $28.5 \mathrm{~d}$ (Figure 5).

Two behaviors became apparent in radio-tagged juvenile fall chinook salmon while in the Little Goose Dam forebay. The first was a pattern of circling the forebay, and the second consisted of upstream excursions of varying duration with the fish eventually returning to the forebay. Peak numbers of detections in the forebay telemetry record were observed at 0500 hours and again between 1600 and 1900 hours, and detection frequency did not appear to be related to mean hourly discharge (Figure 6). No spill occurred during this study, so all discharge was through the turbines.

Forty-eight fish met the initial encounter requirements, and these encounters were used to describe how juvenile fall chinook salmon approach Little Goose Dam. Most (60\%) entered the forebay at the northern barge, and continued their approach to the dam along the north shore, with $73 \%$ being detected initially at the 


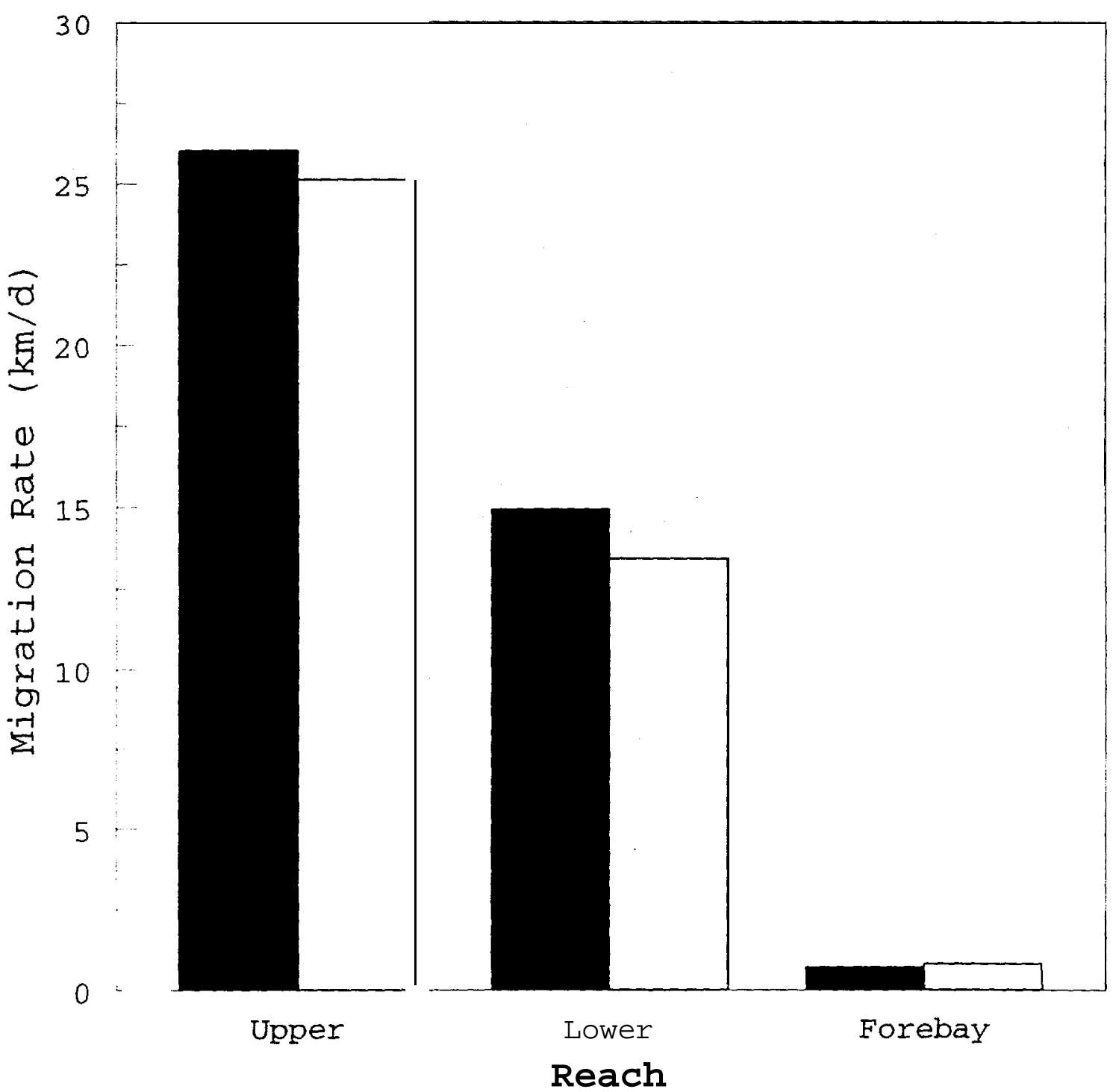

\section{$1995 \square 1996$}

Figure 3.- Median migration rate $(\mathrm{km} / \mathrm{d})$ of radio-tagged juvenile fall chinook salmon through three reaches of Little Goose Reservoir. The upper reach was $45.9 \mathrm{~km}$ from the Lower Granite Dam tailrace to New York Island. The lower reach was $14.4 \mathrm{~km}$ from New York Island to the Little Goose Dam forebay boat restricted zone. The forebay section was $0.6 \mathrm{~km}$ from the upper end of the boat restricted zone to exit gates at the juvenile fish collection facility or immediately below the dam. 
Table 2 .-Migration rates and associated residence times of radio-tagged juvenile fall chinook salmon in various reaches of Little Goose Reservoir. Abbreviations are: LGR - Lower Granite Dam; NYI - New York Island; LGO - Little Goose Dam; Forebay the LGO forebay; Exit - detected below LGO.

\begin{tabular}{|c|c|c|c|c|}
\hline \multirow[b]{2}{*}{ Reach } & \multicolumn{2}{|c|}{ Migration Rate $(\mathrm{km} / \mathrm{d})$} & \multicolumn{2}{|c|}{ Residence Time (d) } \\
\hline & 1995 & 1996 & 1995 & 1996 \\
\hline \multicolumn{5}{|l|}{ LGR - NYI } \\
\hline Minimum & 9.5 & 3.0 & 4.8 & 15.4 \\
\hline Quartile 1 & 19.3 & 19.60 & 2.4 & 2.3 \\
\hline Median & 26.0 & 24.80 & 1.8 & 1.8 \\
\hline Quartile 3 & 36.4 & 37.80 & 1.3 & 1.2 \\
\hline Maximum & 49.5 & 48.30 & 0.9 & 1.0 \\
\hline \multicolumn{5}{|l|}{ NYI - LGO } \\
\hline Minimum & 1.5 & 1.4 & 9.6 & 10.0 \\
\hline Quartile 1 & 10.4 & 9.1 & 1.4 & 1.6 \\
\hline Median & 14.9 & 13.40 & 1.0 & 1.1 \\
\hline Quartile 3 & 24.5 & 19.60 & 0.6 & 0.7 \\
\hline Maximum & 63.6 & 44.70 & 0.2 & 0.3 \\
\hline \multicolumn{5}{|l|}{ Forebay } \\
\hline Minimum & 0.02 & 0.01 & 28.5 & 47.6 \\
\hline Quartile 1 & 0.3 & 0.3 & 2.2 & 1.7 \\
\hline Median & 0.7 & 0.9 & 0.8 & 0.7 \\
\hline Quartile 3 & 2.3 & 2.3 & 0.3 & 0.3 \\
\hline Maximum & 30.3 & 18.30 & 0.02 & 0.03 \\
\hline \multicolumn{5}{|l|}{ LGR - LGO } \\
\hline Minimum & 4.9 & 3.7 & 12.4 & 16.3 \\
\hline Quartile 1 & 16.8 & 15.50 & 3.6 & 3.9 \\
\hline Median & 20.1 & 20.20 & 3.0 & 3.0 \\
\hline Quartile 3 & 29.1 & 26.80 & 2.1 & 2.3 \\
\hline Maximum & 50.0 & 46.30 & 1.2 & 1.3 \\
\hline \multicolumn{5}{|l|}{ LGR - Exit } \\
\hline Minimum & 1.9 & 1.2 & 31.6 & 52.0 \\
\hline Quartile 1 & 9.9 & 9.2 & 6.2 & 6.50 \\
\hline Median & 14.4 & 15.50 & 4.2 & 3.90 \\
\hline Quartile 3 & 17.6 & 21.20 & 3.4 & 2.80 \\
\hline Maximum & 29.0 & 36.90 & 2.1 & 1.60 \\
\hline
\end{tabular}



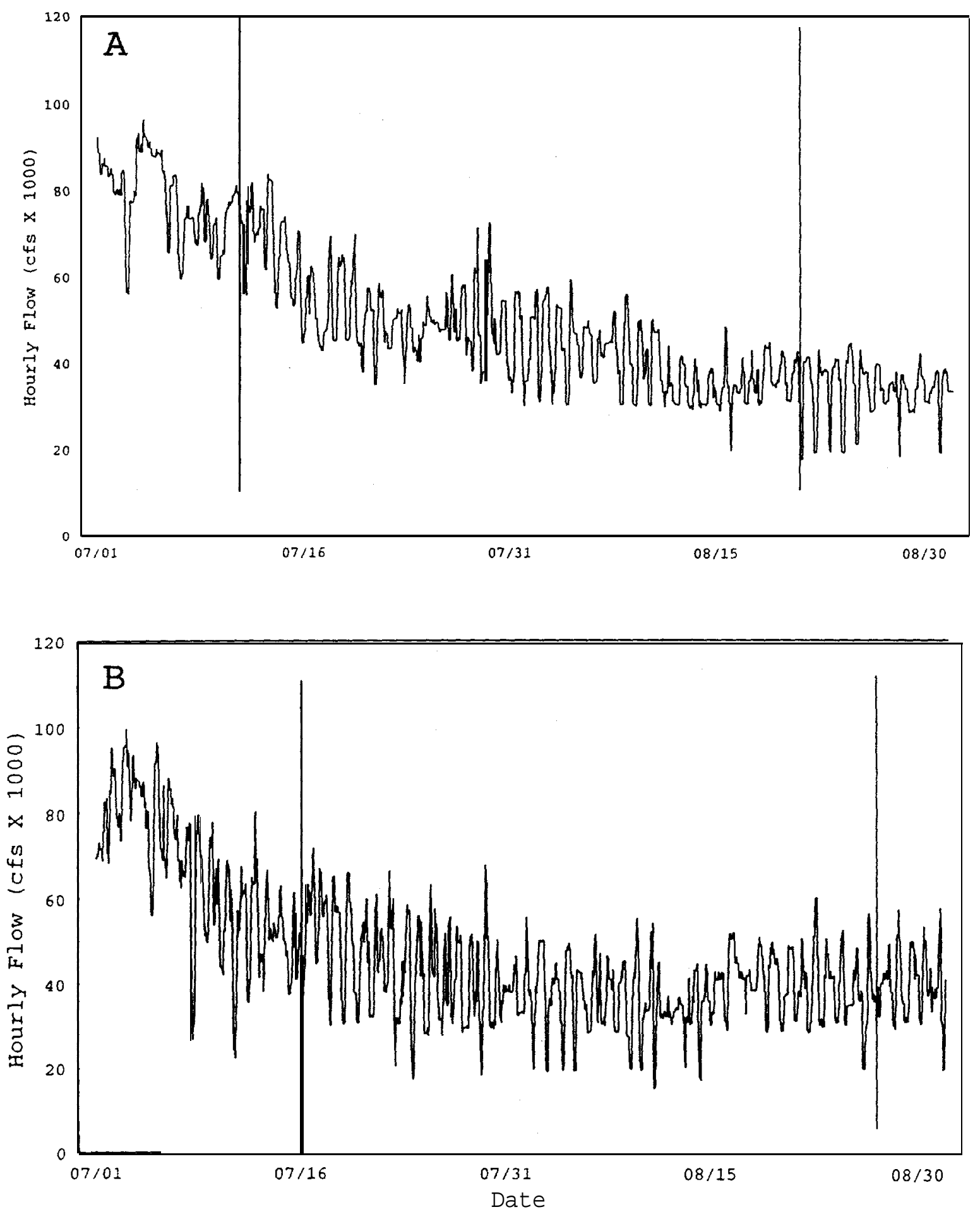

Figure 4.-Hourly turbine discharge at Little Goose Dam between July 1, and August 31, (A) 1995, (B) 1996. Vertical bars mark the beginniing and end of the study each year. 

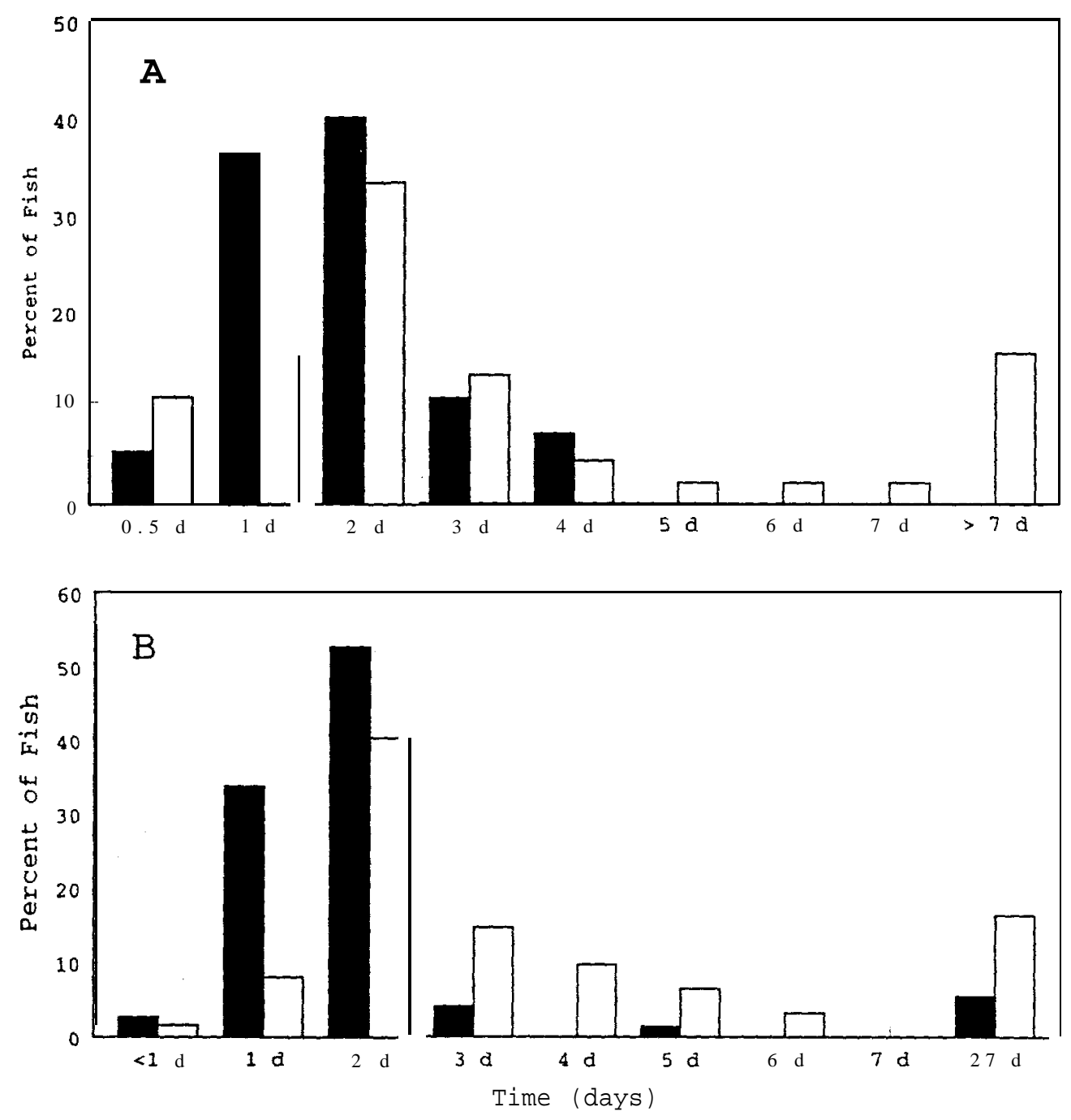

$\square$ upper $\square$ Lower

Figure 5.- Time required for radio-tagged juvenile fall chinook salmon to migrate through upper and lower reservoir reaches in 1995 (A) and 1996 (B). The upper reach consisted of the $45.9 \mathrm{~km}$ from the Lower Granite Dam tailrace to New York Island. Passage through the lower reach was New York Island to exiting the study site and contained both the lower reservoir $(14.4 \mathrm{~km})$ and forebay reaches $(0.6 \mathrm{~km})$. 

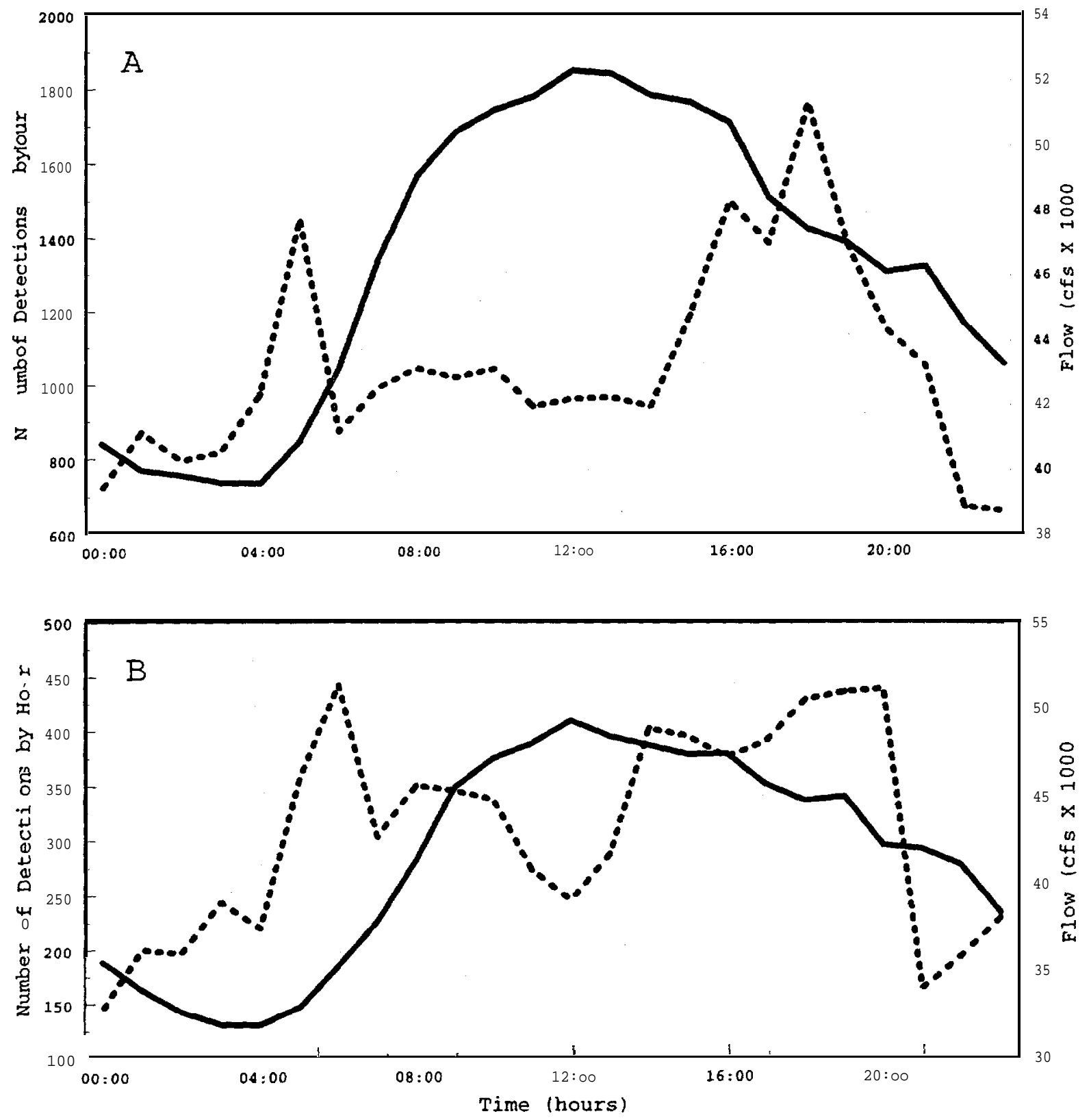

Detections Flow

Figure 6. -Total number of detections over the entire study period versus mean hourly discharge at Little Goose Dam, A: between July 11 and August 24, 1995, B: between July 17 and August 26, 1996. 
earthen dam or spillway. Five of these fish had initial encounter records consisting of only a single dam bank detection and were excluded from further analysis. Initial encounter records for the remaining fish had a median length of $2 \mathrm{~h} 36 \mathrm{~min}$ $(\mathrm{N}=43$ range $3 \mathrm{~min}-17 \mathrm{~h} 58 \mathrm{~min}$ ). Fourteen initial dam encounters terminated in upstream excursions, and one fish passed the facility and was detected at an exit bank during its initial dam encounter.

We documented 116 separate dam encounters $\geq 2$ h of radio tagged juvenile fall chinook salmon. Fish with initial encounter records $\geq 2 \mathrm{~h}(\mathrm{~N}=24$, median $4 \mathrm{~h} 38 \mathrm{~min}$, range $2 \mathrm{~h}-17 \mathrm{~h} 58$ min) averaged 6.0 forebay crosses before being lost from the telemetry record for $>1 \mathrm{~h}$, and had a median score of 1.3 forebay crosses per hour (Figures 7, 8). Subsequent encounter records had a median duration of $4 \mathrm{~h} 32 \mathrm{~min}$ ( $\mathrm{N}=96$, range $2 \mathrm{~h}-19 \mathrm{~h} 25$ min), with fish averaging 4.4 forebay crosses. The median number of forebay crosses per hour for subsequent encounters was 0.85 , and differed significantly from that of initial encounter records (Wilcoxon 2-Sample Test, $Z=2.9103, P=0.0036$ ).

Thirty-four fish made upstream excursions based on our criteria, and these had a median duration of $4 \mathrm{~h} 31 \mathrm{~min}$ (range 1 h $2 \mathrm{~min}-170 \mathrm{~h} 30 \mathrm{~min}(7.1 \mathrm{~d})$ ). Individual fish made up to six separate upstream excursions, and five traveled at least $14.4 \mathrm{~km}$ upriver and were detected at New York Island.

\section{Discussion}

The residence times and migration rates of juvenile fall chinook salmon in Little Goose Reservoir indicate downstream migration is directly related to reservoir water velocity. This suggests that the lower portion of the reservoir and the forebay, where water velocity is low, may be areas where much of the migrational delay is occurring. Decreased migration rates in yearling chinook salmon occur concurrently with decreased water velocity (Raymond 1968), who documented a decrease in migration rate from 47 to $13 \mathrm{~km} / \mathrm{d}$ after fish entered the impounded waters of McNary Reservoir. Migration rates then returned to preimpoundment levels $(40 \mathrm{~km} / \mathrm{d})$ after re-entering the free-flowing Columbia River below McNary Dam [the study was conducted prior to the completion of John Day Dam]. Raymond (1969) also documented decreased migration rates in juvenile chinook salmon [probably spring race] between Ice Harbor and The Dalles dams from 18 to 11 $\mathrm{km} / \mathrm{d}$ after the completion of John Day Dam. Finally, Thorpe et al. (1981) found the downstream displacement of Atlantic salmon Salmosalar smolts was related to surface currents in that their 


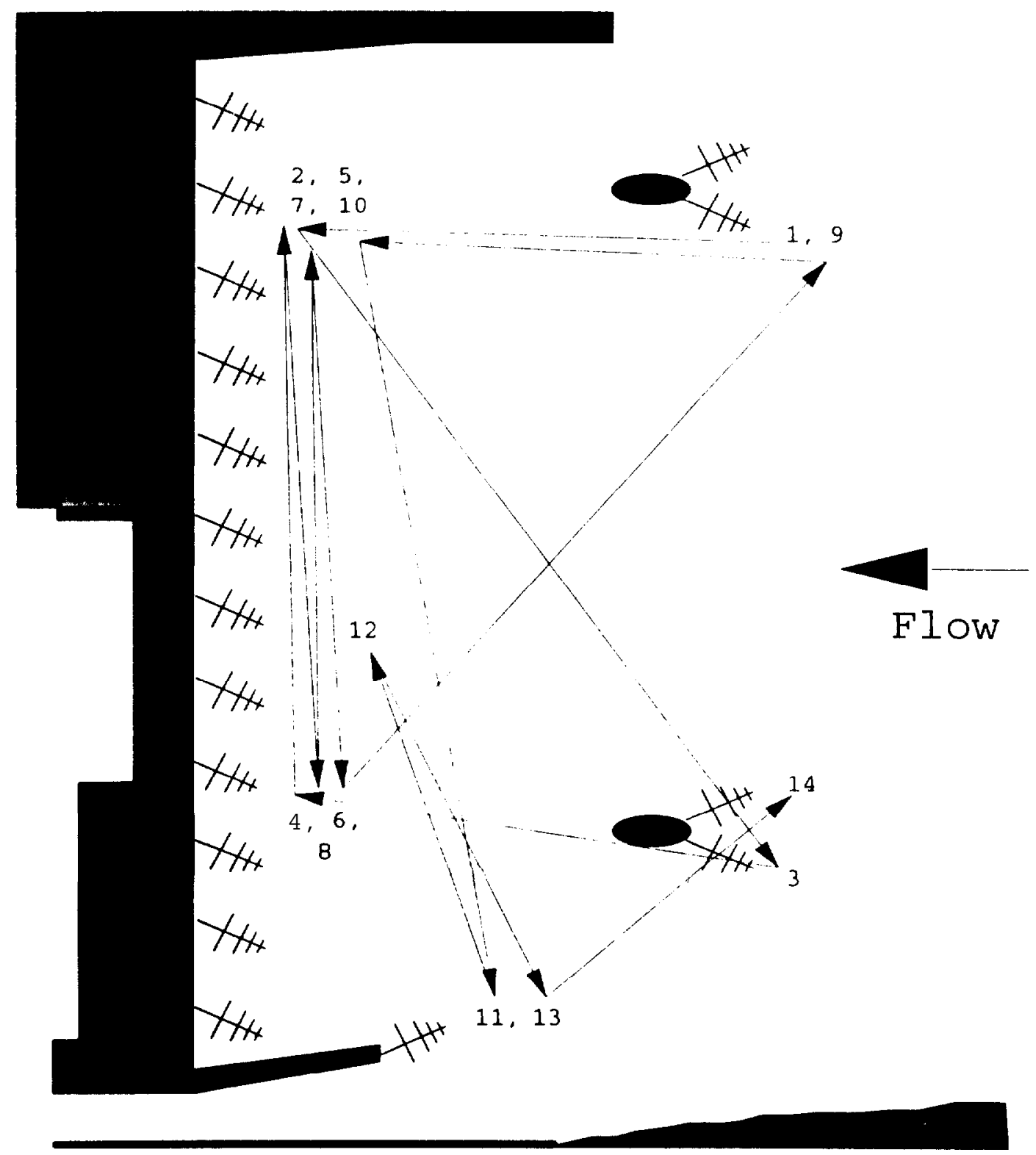

Figure 7. -Chronological order of 14 locations for fish 150.740 during its 9 h 55 min initial encounter with Little Goose Dam in 1995. This fish was later detected in the Little Goose Dam juvenile fish collection facility 93 h 42 min after its initial forebay detection. 


$$
[
$$


displacement was just slightly faster than that of free drifting drogues. We believe a similar relationship exists between water velocity and juvenile fall chinook salmon. This would explain the differences in migration rate between the relatively high velocity upper reach and the low velocity lower reach. If this relationship proves true, one strategy to reduce residence time in outmigrating smolts may be to increase lower reservoir and forebay current velocities.

The percentage of smolts that do find their way past Little Goose Dam relatively quickly may be masking a larger threat to the smolt population as a whole. While, a median passage time of $0.8 \mathrm{~d}$ through the forebay may not be a substantial delay, almost $20 \%$ of wild outmigrants remain in this area for $\geq 7 \mathrm{~d}$ and represents a significant portion of the population. If a fish that remained in the forebay $7 \mathrm{~d}$ had been able to maintain even the reduced migration rate observed in the lower reservoir section it would have traveled $104 \mathrm{~km}$ downstream instead of only $0.6 \mathrm{~km}$. Traveling at the rate observed in the upper reach, it would have migrated $182 \mathrm{~km}$ downstream in the same amount of time. In addition to getting smolts to the ocean sooner, reducing time spent in the forebay also reduces the predation risk associated with this area (Poe et al. 1991; Vigg et al. 1991).

We believe the circling and upstream excursions associated with juvenile fall chinook salmon behavior in the forebay are also associated with the reduced water velocity. Fried et al. (1978) found current to be the main factor influencing the route and rate of outmigrating Atlantic salmon smolts, and Thorpe et al. (1981) reported the direction of Atlantic salmon smolt displacement and water movement to be significantly correlated. It is reasonable that seaward migrating Pacific salmon would also use current as a guide through the system. Upon entering an area of severely reduced flow this mechanism would conceivably break down and the outmigrant would try to locate the lost velocity stream. It is this "search pattern" that we believe is manifesting itself in the observed circling behavior. If, then, after a period of searching, the out-migrant was still unable to find the current past the obstruction (in this case into the juvenile collection facility or turbine) an upstream excursion would allow the migrant to relocate the lost flow and take another run at passing the obstruction. Fried et al. (1978) describes a similar situation where Atlantic salmon smolts entered shallow water or when tidal influences caused current reversals. At these times smolts were reported to stop, mill about, or to begin swimming against the current. 


\section{References}

Achord, S., G.M. Matthews, O.W. Johnson, and D.M. Marsh. 1996. Use of passive integrated transponder (PIT) tags to monitor migration timing of Snake River chinook salmon smolts. North American Journal of Fisheries Management 16:302-313.

Bentley, W.W., and H.L. Raymond. 1976. Delayed migrations of yearling chinook salmon since completion of Lower Monumental and Little Goose dams on the Snake River. Transactions of the American Fisheries Society 105:422-424.

Berggren, T.J. and M.J. Filardo. 1993. An analysis of variables influencing the migration of juvenile salmonids in the Columbia River Basin. North American Journal of Fisheries Management 13:48-63

Connor, W.P., H.L. Burge, and W.H. Miller. 1993. Rearing and emigration of naturally produced Snake River fall chinook salmon juveniles. Pages 86-116 in D.W. Rondorf and W.H. Miller, editors. Identification of the spawning, rearing, and migratory requirements of fall chinook salmon in the Columbia River Basin. Annual Report to Bonneville Power Administration, Contract DE-AI79-91BP21708, Portland, Oregon.

Connor, W.P., H.L. Burge, and W.H. Miller. 1994. Rearing and emigration of naturally produced Snake River fall chinook salmon juveniles. Pages 92-119 in D.W. Rondorf and W.H. Miller, editors. Identification of the spawning, rearing, and migratory requirements of fall chinook salmon in the Columbia River Basin. Annual Report to Bonneville Power Administration, Contract DE-AI91BP21708, Portland, Oregon.

Dawley, E.M., and eight co-authors. 1986. Migrational characteristics, biological observations, and relative survival of juvenile salmonids entering the Columbia River Estuary, 1966-1983. Final Report to Bonneville Power Administration, Contract DE-A179-84BP39652.

Fish Passage Center. 1994. Fish passage center annual report 1993. Annual Report to Bonneville Power Administration, Contract DE-FC79-88BP38906

Fried, S.M., J.D. MCCleve, and G.W. LaBar. 1978. Seaward migration of hatchery-reared Atlantic salmon, Salmosalar, smolts in the Penobscot River estuary, Maine: Riverine 
movements. Journal of the Fisheries Research Board of Canada 35:76-87.

Kelly, J.E., and N.S. Adams. 1996. Range tests on radio tags considered for using in Lower Granite Reservoir, Washington. Pages 14-29 in Rondorf, D.W. and M.J. Banach, editors. Migrational characteristics of juvenile chinook salmon and steelhead in Lower Granite Reservoir and tributaries, Snake River. Report to the U.S. Army Corps of Engineers, Contract E 8630151, Walla Walla Washington.

Muir, W.D., and ten co-authors. 1995. Survival estimates for the passage of juvenile salmonids through Snake River dams and reservoirs, 1994. Annual Report to Bonneville Power Administration, Contract DE-AI79-93BP10891.

Netboy, A. 1973. The salmon: their fight for survival. Houghton Mifflin Company, Boston.

Poe, T.P., H.C. Hansel, S. Vigg, D.E. Palmer, and L.A. Prendergast. 1991. Feeding of predaceous fishes on out-migrating juvenile salmonids in the Columbia River Canadian Journal of Fisheries and Aquatic Sciences $49: 2551-2565$.

Prentice, E.F., T.A. Flagg, and C.S. McCutcheon. 1990. Feasibility of using implantable passive integrated transponders (PIT) tags in salmonids. American Fisheries Society symposium 7:317-322.

Raymond, H.L. 1968. Migration rates of yearling chinook salmon in relation to flows and impoundments in the Columbia and Snake rivers. Transactions of the American Fisheries Society $97: 356-359$.

Raymond, H.L. 1969. Effect of John Day Reservoir on the migration rate of juvenile chinook salmon in the Columbia River. Transactions of the American Fisheries Society $98: 513-514$.

Raymond, H.L. 1979. Effects of dams and impoundments on migrations of juvenile chinook salmon and steelhead from the Snake River, 1966 to 1975. Transactions of the American Fisheries Society 108:505-529.

SAS Institute Inc. 1990. SAS Procedures Guide, Version 6, Third Edition, Cary, North Carolina: SAS Institute Inc. 
Smith, S.G., J.R. Skalski, and A. Giorgi. 1993. Statistical evaluation of travel time estimation based on data from freeze-branded chinook salmon on the Snake River, 1982-1990. Annual Report to Bonneville Power Administration, Contract DE-BI79-91PB35885.

Snelling, J.C. 1996. Laboratory tests to determine the effects of radio transmitter implantation on juvenile chinook salmon. Pages $1-13$ in Rondorf, D.W. and M.J. Banach, editors. Migrational characteristics of juvenile chinook salmon and steelhead in Lower Granite Reservoir and tributaries, Snake River. Report to the U.S. Army Corps of Engineers, Contract E 8630151, Walla Walla Washington (Draft).

Thorpe, J.E., L.G. Ross, G. Struthers, and W. Watts. 1981. Tracking Atlantic salmon smolts, Salmosalar I., through Loch Voil, Scotland. Journal of Fish Biology 19:519-537.

Vigg, S., T.P. Poe, L.A. Prendergast, and H.C. Hansel. 1991. Rates of consumption of juvenile salmonids and alternative prey fish by northern squawfish, walleyes, smallmouth bass, and channel catfish in John Day Reservoir, Columbia River. Transactions of the American Fisheries Society 120:230-246. 


\section{CHAPTER FOUR}

\section{Nearshore Movements of Juvenile Fall Chinook Salmon in the Columbia River}

by

D.A. Venditti, M.A. Tennier, and D.W. Rondorf United States Geological Survey Biological Resources Division Columbia River Research Laboratory Cook, WA 98605, USA 


\section{Introduction}

Our knowledge of juvenile fall chinook salmon Oncorbynchus tshareytscha behavior in nearshore rearing areas has increased in recent years. Passive integrated transponder (PIT) tags have been used to examine rearing site fidelity and to estimate movement rates in the free-flowing Snake River and in Lower Granite Reservoir (Connor et al. 1993; Connor et al. 1994a; Connor et al. 1994b). Electrofishing and beach seining have been used to identify preferred rearing habitats in the Columbia River

(Key 1994a; Key 1994b). We attempted to build upon these studies by focusing more closely on nearshore movements, behavior, and habitat use. The study reported here was conducted in the Hanford Reach of the Columbia River to use available fall chinook salmon as surrogate experimental animals for the threatened snake River stock. Our objectives were to 1) document and compare diel patterns in the direction and magnitude of juvenile fall chinook salmon movements in nearshore habitats throughout the rearing season, and 2) investigate the effect of differing flow and substrate composition in nearshore areas on juvenile fall chinook salmon movement patterns.

\section{Study Area}

The 1995 study area was located near Richland, Washington between river kilometer (Rkm) 547 and 554 on the Columbia River (Figure 1). River kilometer information was obtained from U.S. Geological Survey 7.5 minute topographic maps.

\section{Methods}

\section{Field Procedures}

Paired fyke nets were fished during three periods, referred to as "runs", at two locations in 1995. The early, middle, and late runs were between the dates of April 10-19, May 8-17, and June 5-14, respectively. The first location had a shallow gradient, sand substrate and low flow, and was the same as used by Venditti and Garland (1996). The second location was characterized by a steeper gradient, cobble substrate, and relatively high flow. Sites are referred to as "sand" or "cobble" throughout this report. Fyke net pairs were fished for five consecutive days at both sites during each run, and were set to collect fish traveling parallel to shore in both upstream and downstream directions (Figure 2). These nets were also designed 


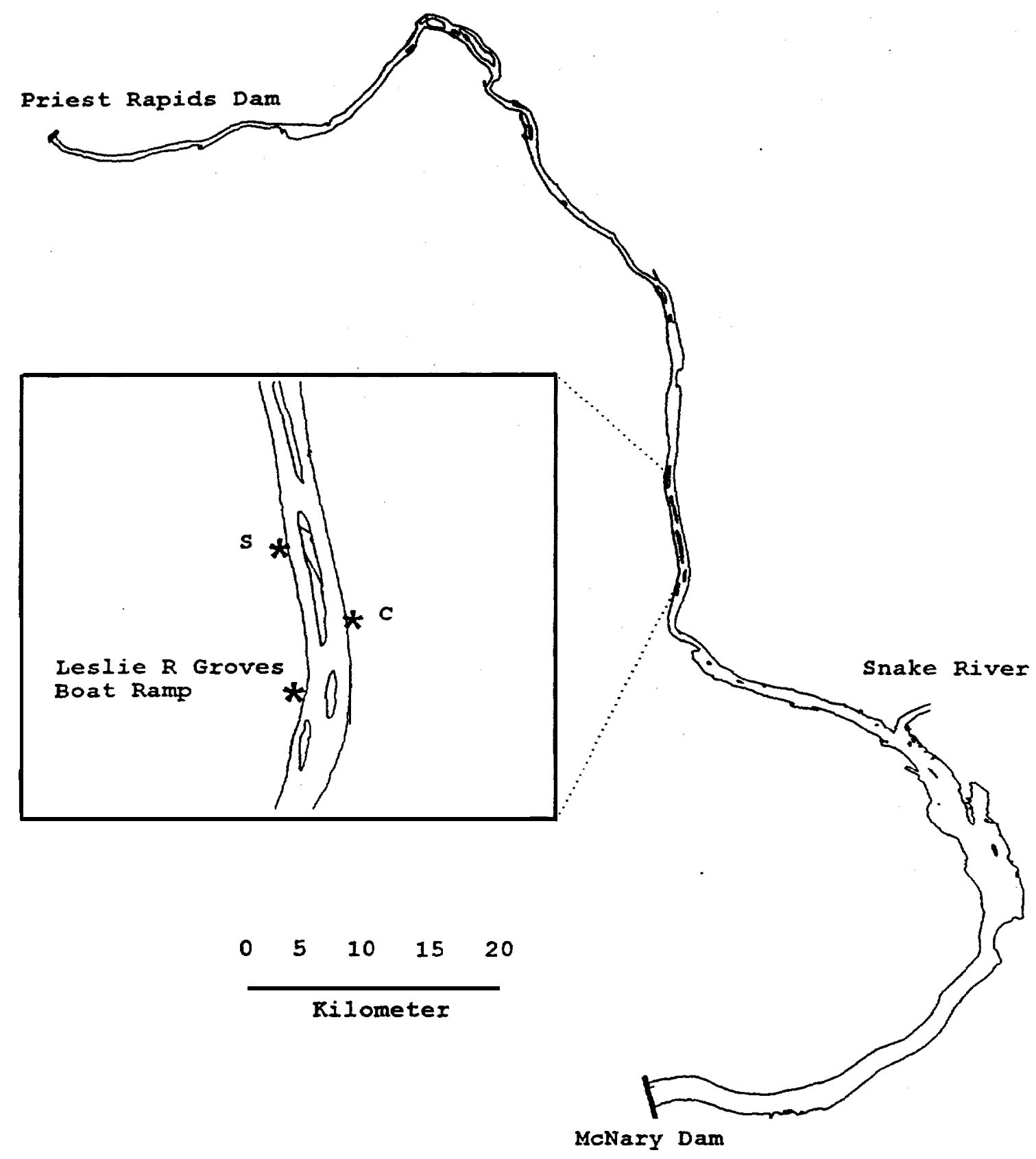

Figure 1.-Map of the study area sampled with paired fyke nets between April and June, 1995. The inset gives the location of the sand site (S), and the cobble site (C). Leslie R. Groves boat ramp is also shown to provide an easily identifiable landmark. 


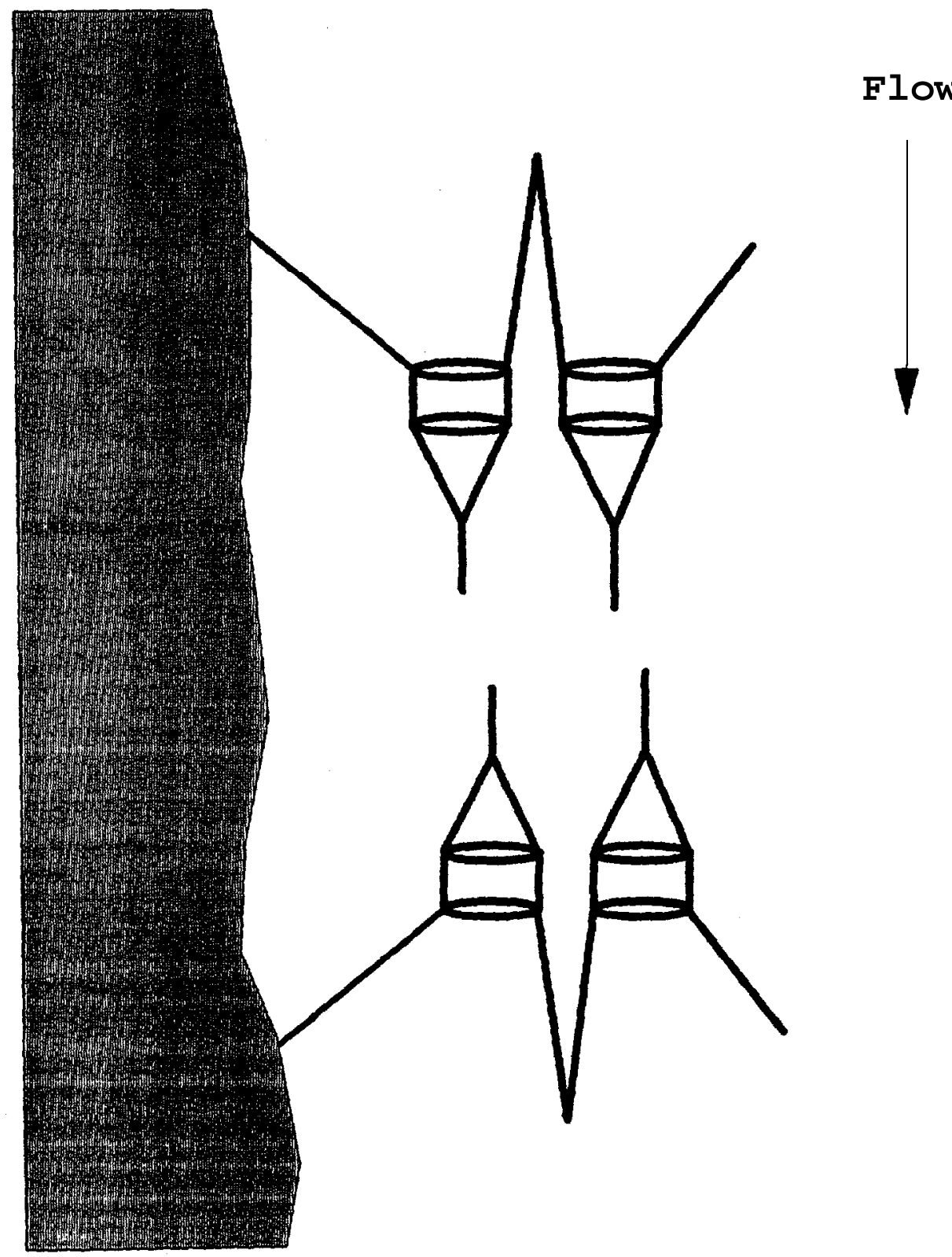

F'igure 2. - Fyke net configuration used in the nearshore movement study in the Columbia River, April - June, 1995. 
keep nearshore and offshore traveling fish separated. Traps were set so the center and outer lead anchors were approximately 0.75 and $1.3 \mathrm{~m}$ deep, respectively. Trap frames measured $1.2 \mathrm{~m}$ deep by $1.2 \mathrm{~m}$ wide, leads were $7.6 \mathrm{~m}$ long by $2.0 \mathrm{~m}$ deep, and mesh size was $3.2 \mathrm{~mm}$ on both traps and leads.

Once set, nets were fished continuously, and fish were removed every 2-3 h depending on the number collected previously and the amount of debris in the nets. Fish from the nearshore and offshore traps were placed in separate buckets, lightly anesthetized with MS-222, identified to species, and enumerated. Additionally, twenty individuals of each species collected in each trap were measured to the nearest $1 \mathrm{~mm}$ fork length (FL), and weighed to the nearest $0.1 \mathrm{~g}$. After handling, fish were allowed to recover in fresh river water before release.

Selected environmental measurements were also taken at the time of fish collection. These included water temperature, depth and velocity, and light intensity. Depth and velocity readings were collected using a digital velocity meter and wading staff. Measurements were collected at $20,40,60$ and $80 \%$ of the distance between shore and the middle trap lead and between the center and outer trap leads. Depth was also collected at the center and outer lead anchors. When water depth was $\leq 0.75 \mathrm{~m}$, velocity readings were taken at $60 \%$ depth, and when $>0.75 \mathrm{~m}$ measurements were taken at 20 and $80 \%$ depth.

\section{Data Analysis}

Catch rates at each location were compared between nets (upstream versus downstream) and traps (nearshore versus offshore) to evaluate the direction, location, and timing of subyearling chinook salmon movements. Catch per hour (CPH) was calculated by dividing the number of fish collected in each trap by the number of hours the net fished. To test for differences in movement patterns by time, mean $\mathrm{CPH}$ values were calculated for the following blocks: nighttime (2101-0300 hours), dawn (0301-0900 hours), daytime (0901-1500 hours), and dusk (1501-2100 hours).

Catch rates were examined graphically and statistically using analysis of variance (ANOVA) and t-tests (SAS 1990). When significant differences were detected in the ANOVA analysis the Student-Newman-Keuls (SNK) test was used to identify which factor means differed. Analysis of variance was used to determine if catch rates varied by time period or direction of travel. A $t$-test was used to test for differences in catch rates between 
the nearshore and offshore traps. Separate analyses were performed for each run. Raw catch rates are presented graphically, but these data were normalized using the transformation

$$
\mathrm{CPH},=\log _{,},\left(\mathrm{CPH}_{r}+1\right)
$$

where $\mathrm{CPH}$, is the normalized catch rate and $\mathrm{CPH}$, is the raw catch rate for statistical analysis. The constant 1 was added to all $\mathrm{CPH}$, estimated to provide a definition for the expression where $\mathrm{CPH},=0$. Statistical significance was assumed at $\alpha \leq 0.05$.

The volume of water $\left(\mathrm{m}^{3} / \mathrm{h}\right)$ sampled by each trap in the downstream fishing net during each net set was calculated to determine if the differences in trap catch described by Venditti and Garland (1996) could be explained by disproportionate sample volumes. The overall mean water velocity $\left(v_{w}\right)$ through the two traps was calculated by estimating the velocity at the midpoint of each cell (Figure 3), and weighting that estimate with the cell frontal area using the formula

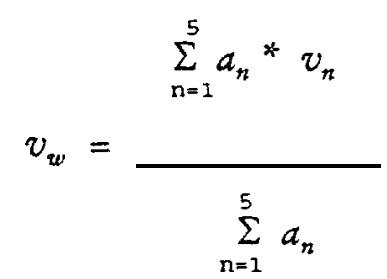

where $a$, is the cell frontal area and $v_{n}$ is the estimated velocity $(\mathrm{m} / \mathrm{s})$ at the midpoint of each cell. The volume $(q)\left(\mathrm{m}^{3} / \mathrm{s}\right)$ sampled by each trap was then estimated using the formula

$$
q=\sum_{n=1}^{5} a_{1}^{*} v_{w} * t_{s}
$$

where $a$, is the cell frontal area $\left(\mathrm{m}^{2}\right), v_{w}$ is the average velocity $(\mathrm{m} / \mathrm{s})$ through the trap, from above, and $t_{s}$ is the time in seconds the net fished. These results were then converted to $\mathrm{m}^{3} / \mathrm{h}$. The frontal area of each cell was estimated by dividing the cell into a rectangle and a triangle and summing their areas (Figure 3). Volume estimates through the upstream fishing net are not reported because the position of the net obstructed the current, resulting in artificially reduced measurements. 


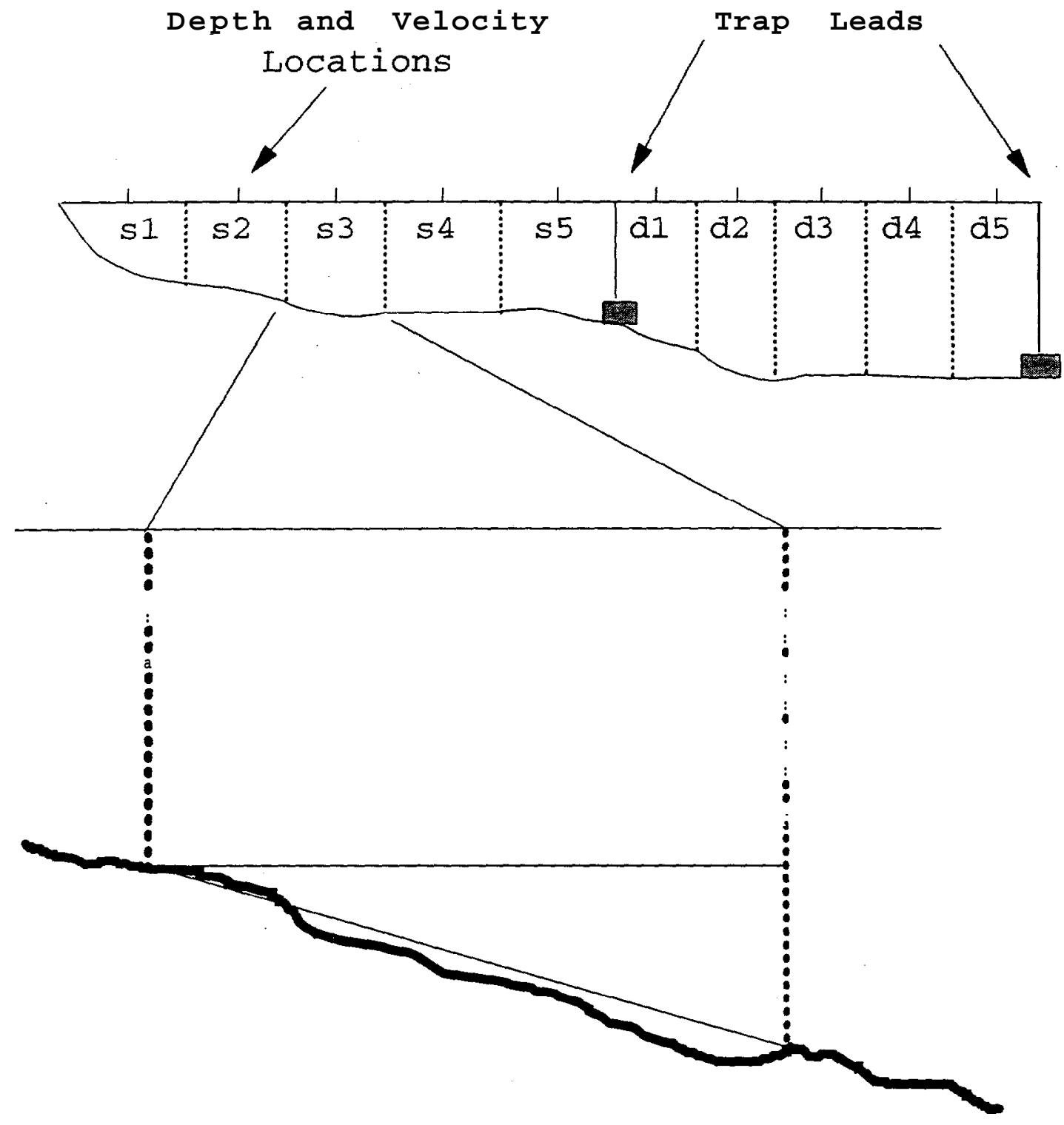

Figure 3. -Horizontal view of the fyke net design used to collect juvenile fall chinook salmon in 1995. Vertical tics are locations where depth and velocity were recorded. Cells with an "s" prefix are between the shoreline and center lead, and those with a "d" are between the center and outer leads. The cell diagrams how cell frontal area was calculated to estimate volume of water sampled for each net set. 
Cell midpoint velocities were calculated by the method described in (Brooks et al. 1991). In this method, velocity measurements are taken at the edges of the cell, and their mean is considered the velocity at the cell midpoint (Figure 3). Velocities were not collected at the two leads. The velocity at the center lead was estimated as the mean of the two velocity measurements on either side of the lead, and the velocity at the outside lead was considered to be the same as the nearest measured velocity.

\section{Results}

In 1995, we collected a total of 56,317 juvenile fall chinook salmon during the three runs. In the early run 11,869 were collected, and had a mean fork length of $42.2 \mathrm{~mm}(\mathrm{~N}=2,970$, $\mathrm{SD}=2.56$, range $37-71 \mathrm{~mm})$, and weight of $0.70 \mathrm{~g}(\mathrm{~N}=536, \mathrm{SD}=$ 0.20 , range $0.3-1.9 \mathrm{~g})$. Average size of the 42,527 juveniles from the second run increased only slightly to $43.9 \mathrm{~mm} \mathrm{FL} \mathrm{(N=}$ $4,544, \mathrm{SD}=4.13$, range 34-105 nun), and $0.77 \mathrm{~g}(\mathrm{~N}=607, \mathrm{SD}=$ 0.29 , range $0-3-2.5 \mathrm{~g})$. We collected 1,921 juvenile fall chinook salmon in the third run, and their mean size had increased to $53.8 \mathrm{~mm} \mathrm{FL}(\mathrm{N}=1,495, \mathrm{SD}=7.90$, range $30-89 \mathrm{~mm})$ and $1.96 \mathrm{~g}(\mathrm{~N}=$ $591, \mathrm{SD}=1.02$, range $0.2-7.5 \mathrm{~g})$.

Juvenile fall chinook salmon appeared to become more nocturnal as the season progressed. In the first run, mean catch rates over the four time periods peaked during the daytime and dusk at the sand and cobble site, respectively. Peak catches at both sites then occurred at dusk in the second run, and during the nighttime in the third (Figure 4).

Analysis of juvenile fall chinook salmon catch rates indicated that their movements were generally directional and dependent on time period. In the first run, catch rates varied significantly by both time period, and direction at the sand site (ANOVA, period, $\mathbf{F}=3.84, P=0.0116$; direction, $\mathbf{F}=7.88, P=$ 0.0059), but only by direction at the cobble site (ANOVA, period, $\mathbf{F}=1.99, \quad P=0.1175 ;$ direction, $\mathbf{F}=12.88, P=0.0004)$. The SNK test identified daytime catches as being greater than nighttime at the sand site, and downstream catches as being greater than upstream at both sites. During the second run catch rates varied by both time period, and direction at both sites (ANOVA, period, $=7.33, P=0.0002$, sand, $F=7.79, P=0.0001$, cobble; direction; $\mathbf{F}=10.44, P=0.0017$, sand; $F=28.24, P=0.0001$, cobble). Multiple comparison testing identified catch rates during the dusk period as being greater than the other three periods at the sand site, and daytime and dusk catches as greater 

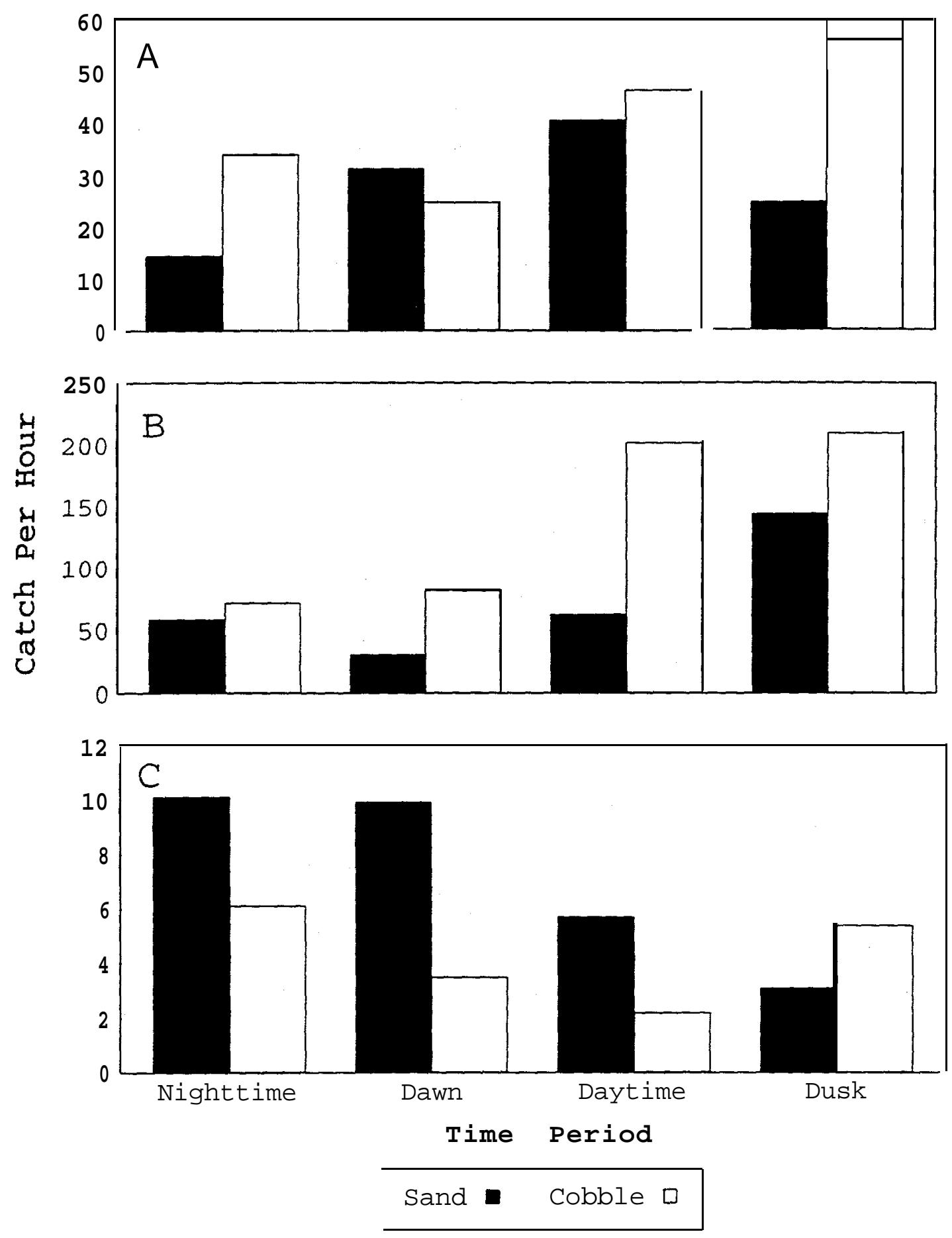

Figure 4. -Mean catch per hour in paired fyke nets during four daily time periods in 1995. (A) early run, April 10 - 19; middle run, May 8-17; and (C) the late run, June 5- 14 . 
than nighttime or dawn catches at the cobble site. Catch rates did not differ between daytime and dusk, or nighttime and dawn at the cobble site. In the final run, catch rates again varied significantly by time period at both sites, but movement was no longer directional at the cobble site (ANOVA, period, $F=6.57, P$ $=0.0004$, sand; $\mathbf{F}=6.92, P=0.0003$, cobble; direction, $F=$ 5.51, $P=0.0204$, sand; F=0.08, $P=0.7810$, cobble). The SNK test identified the following differences at the sand site, nighttime catches were greater than both daytime and dusk, and dawn catches were greater than dusk. At the cobble site nighttime catches were higher than the other three periods, which did not differ.

Regardless of substrate type or direction of travel, juvenile fall chinook salmon catches were higher in the shallow trap during the first two runs (t-test, first runt $=-6.6878, P=$ 0.0001 ; second run $t=-6.3056, P<0.0001)$. In the third run, fish were collected equally at both trap depths (t-test, $t=$ $\left.-1.3937, I^{\prime}=0.1647\right)$.

Plotting catch data for individual net sets along with the volume sampled clearly shows the shifting times of peak catch between runs described above, and demonstrates the differences in flow volume between traps and sites (Figures 5, 6, 7). Volumes sampled by the two traps at the sand site were more similar than at the complex site, where the offshore trap consistently sampled a larger volume of water. Flow differences between the two sites are also readily observable. The higher water velocity present at the complex site is also apparent in the larger volume of water sampled per hour.

\section{Discussion}

Juvenile fall chinook salmon in the Hanford Reach of the Columbia River underwent two distinct changes in behavior between April and June, 1995. First, they appeared to become more nocturnal later in the season. Second, their bias toward downstream movement through the nearshore corridor disappeared by June, although most fish had migrated out of the nearshore area by this time. These trends in behavior were also observed in 1994 (Venditti and Garland 1996). In 1994 and 1995, peak catches of juvenile fall chinook salmon shifted from daytime to nighttime between April and June, and catch rates decreased by approximately an order of magnitude over the same period. Although the lack of an upstream fishing net in April 1994 prevents a comparison of movement in this direction early in the year, downstream catch rates were similar between years, and 

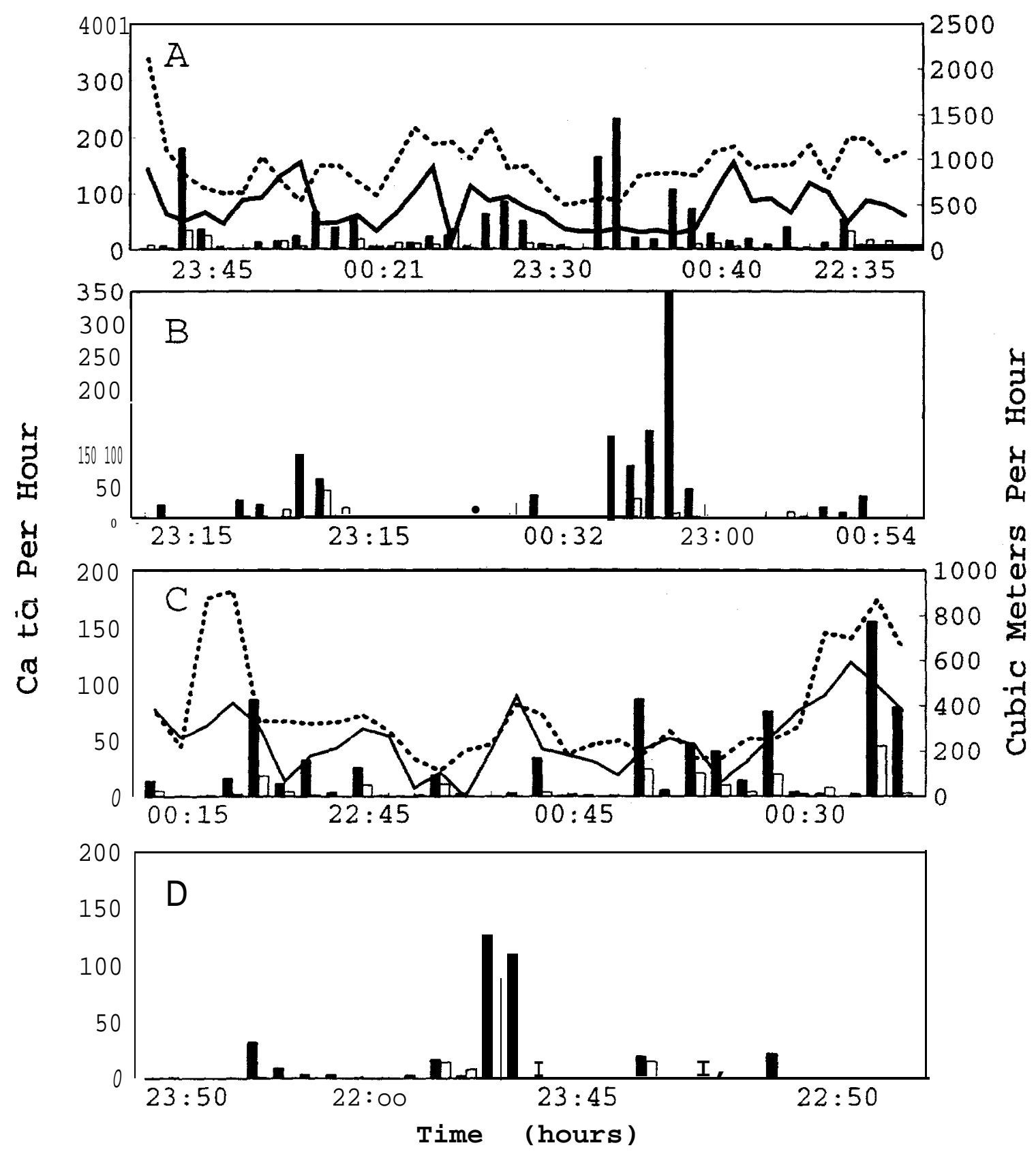

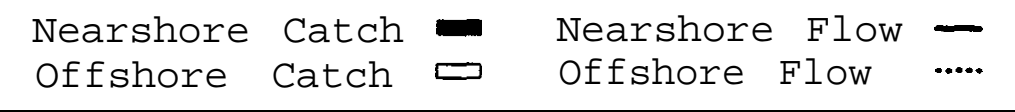

Figure 5. -Paired fyke net catches and volume of water sampled by each downstream fishing trap during the early run, April 10 - 19, 1995. A) Downstream fishing net, cobble site. B) Upstream fishing net, cobble site. C) Downstream fishing net, sand site. D) Upstream fishing net, sand site. 

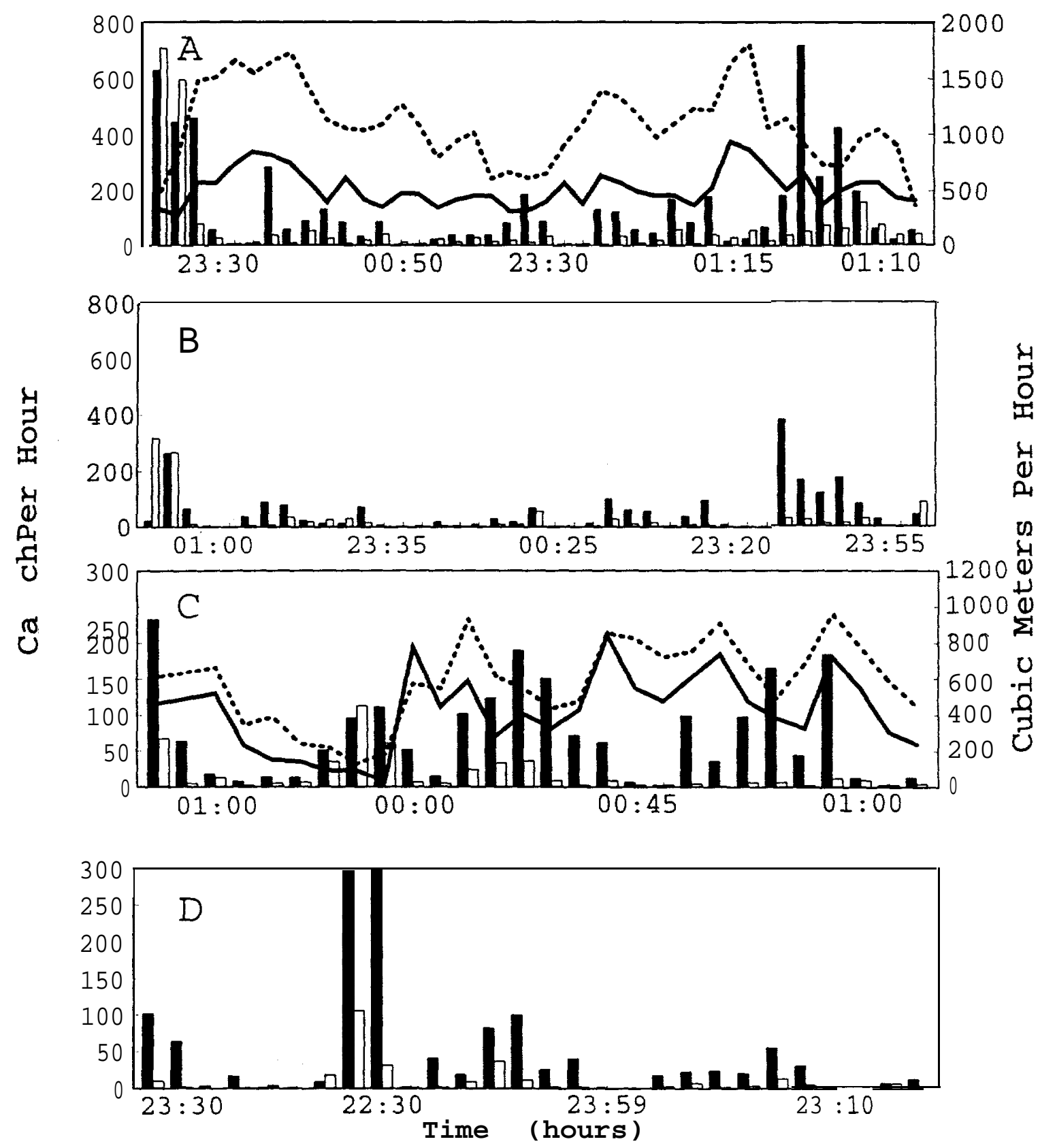

\begin{tabular}{|c|c|c|c|c|}
\hline Nearshore & Catch & $\omega$ & Nearshore Flow & 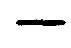 \\
\hline Offshore & Catch & $\varpi$ & Offshore Flow & $\cdots$ \\
\hline
\end{tabular}

Figure 6. -Paired fyke net catches and volume of water sampled by each downstream fishing trap during the middle run, May 8 17, 1995. A) Downstream fishing net, cobble site. B) Upstream fishing net, cobble site. C) Downstream fishing net, sand site. D) Upstream fishing net, sand site. 


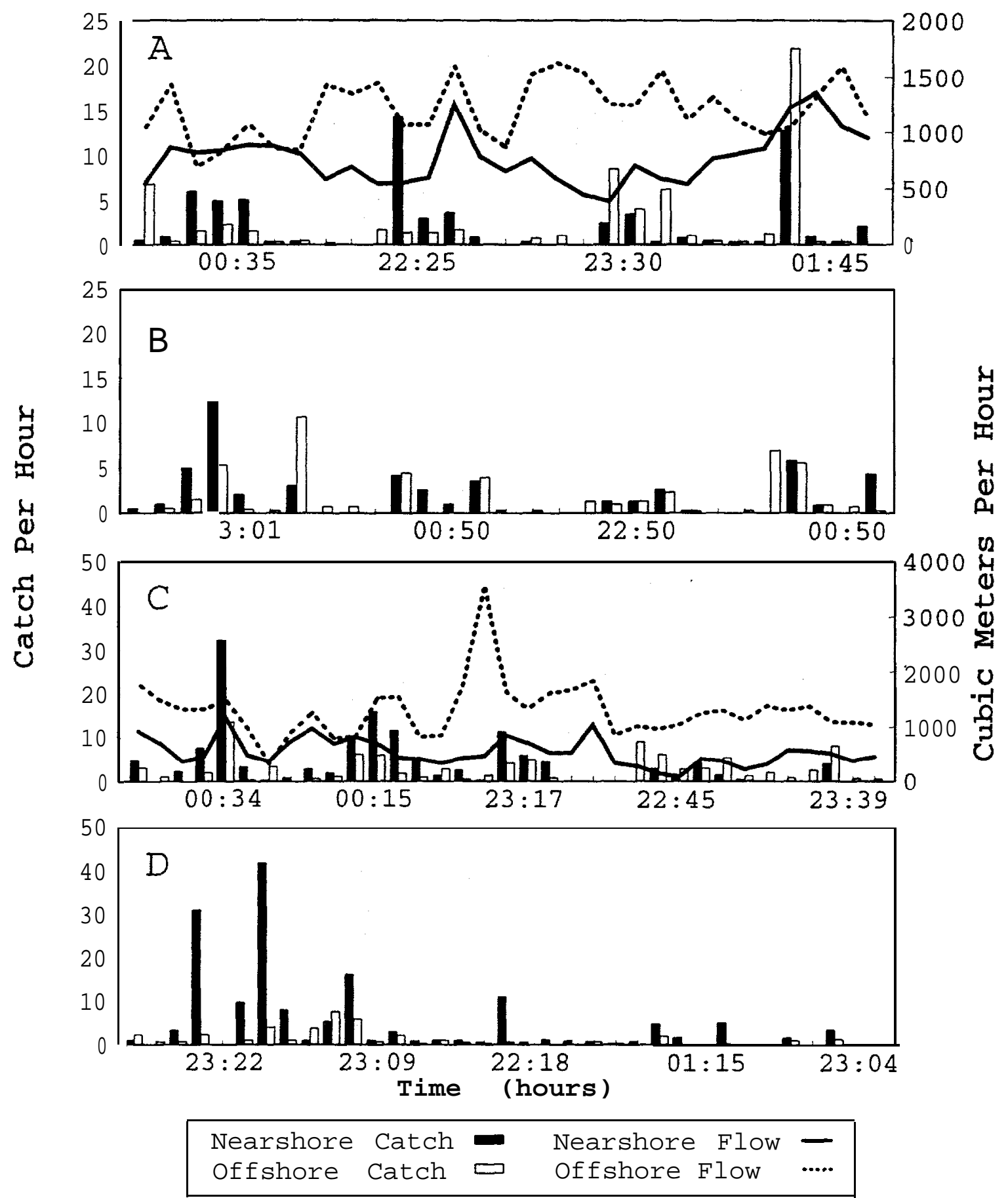

Figure 7. -Paired fyke net catches and volume of water sampled by each downstream fishing trap during the late run, June 5 14, 1995. A) Downstream fishing net, cobble site. B) Upstream fishing net, cobble site. C) Downstream fishing net, sand site. D) Upstream fishing, sand site. 
showed no directional bias by June. The addition of a run in May, 1995 reinforced the supposition that most fish were emigrating from the area during this time, with the highest catch rates observed during the study, and significantly greater catches in the downstream fishing net. Dauble et al. (1989) also collected peak numbers of juvenile fall chinook salmon moving downstream during the middle of May. However, Mains and Smith (1956) collected peak numbers of outmigrants in March and April, with a second peak of mainly age one chinook in June and July. Unfortunately, neither study collected fish moving upstream, so it is unclear whether these peaks represent directed movement.

The lack of a time period effect in the downstream catch at the cobble site during the first run was probably due to relatively high flow rather than a behavioral choice. Many of these fish were probably not developed to the point of being competent enough swimmers to resist the velocity at this site, as a number of fish collected in the first and second runs were recently emerged, and had not yet *'buttoned up" after yolk-sac absorption, or still had button up scars on their ventral surface.

The pattern of catches becoming more nocturnal and less directional, in the later runs, is probably due to behavioral changes affecting the way juvenile fall chinook salmon utilize nearshore areas. Upon reaching a size of approximately $85 \mathrm{~mm}$, these fish begin to actively emigrate (Connor et al. 1993), and the timing of collection of these fish at dams indicate juvenile fall chinook salmon generally migrate at night (Simms and Ossiander 1981). This type of behavior was strongly evident in the nocturnal, highly directional movements observed in the second run. By the third run, while the fish remained nocturnal, the downstream bias in their movements appeared to have diminished. Unfortunately, we do not know whether this was actually due to a decrease in the desire to move downstream, or if they had moved offshore and were migrating in the higher velocities, which would be consistent with other field and laboratory studies (Lister and Genoe 1970; Stein et al. 1972; Taylor 1991).

Comparing individual trap catches to the water volume sampled by each indicate juvenile fall chinook salmon prefer nearshore depths of $0.75 \mathrm{~m}$ or less until about June. This preference for shallow areas may have evolved for several reasons. Shallow water provides protection from piscivorous predators, and may provide some additional growth and feeding advantages. These areas warm quickly and require minimal energy expenditure to hold position. Drifting organisms, which Venditti and Garland (1996) showed to be important food items, are also plentiful in these areas. 


\section{References}

Brooks,K.N., P.F. Folliott, H.M. Gregersen, J.L. Thames. 1991. Hydrology and the management of watersheds. Iowa State University Press, Ames, Iowa.

Connor, W.P., H.L. Burge, and W.H. Miller. 1993. Rearing and emigration of naturally produced Snake River fall chinook salmon juveniles. Pages 86-136 in D.W. Rondorf and W.H. Miller, editors. Identification of the spawning, rearing, and migratory requirements of fall chinook salmon in the Columbia River Basin. Annual Report to Bonneville Power Administration, Contract DE-AI79-91BP21708, Portland, Oregon.

Connor, W.P., H.L. Burge, and W.H. Miller. 1994a. Rearing and emigration of naturally produced Snake River fall chinook salmon juveniles. Pages 92-119 in D.W. Rondorf and K.F. Tiffan, editors. Identification of the spawning, rearing and migratory requirements of fall chinook salmon in the Columbia River basin. Annual Report to Bonneville Power Administration, Contract DE-AI79-91BP21708, Portland, Oregon.

Connor, W.P., H.L. Burge, D. Steele, C. Eaton, and R. Bowen. 1994b. Rearing and emigration of naturally produced Snake River fall chinook salmon juveniles. Pages 41-73 in D.W. Rondorf and W.H. Miller, editors. Identification of the spawning, rearing, and migratory requirements of fall chinook salmon in the Columbia River Basin. Annual Report to Bonneville Power Administration, Contract DE-AI79-91BP21708, Portland, Oregon.

Dauble, D.D., T.L. Page, and R.W. Hanf, Jr. 1989. Spatial distribution of juvenile salmonids in the Hanford Reach, Columbia River. Fishery Bulletin 87:775-790.

Key, L.O., R. Garland, and E.E. Kofoot. 1994a. Nearshore habitat use by subyearling chinook salmon in the Columbia and Snake rivers. Pages 74-107 in D.W. Rondorf and K.F. Tiffan, editors. Identification of the spawning, rearing and migratory requirements of fall chinook salmon in the Columbia River basin. Annual Report to Bonneville Power Administration, Contract DE-AI79-91BP21708, Portland, Oregon. 
Key, L.O., J.A. Jackson, C.R. Sprague, and E.E. Kofoot. 1994b. Nearshore habitat use by subyearling chinook salmon in the Columbia and Snake rivers. Pages 120-150 in D.W. Rondorf and W.H. Miller, editors. Identification of the spawning, rearing, and migratory requirements of fall chinook salmon in the Columbia River Basin. Annual Report to Bonneville Power Administration, Contract DE-AI79-91BP21708, Portland, Oregon.

Lister, D.B., and H.S. Genoe. 1970. Stream habitat utilization by cohabiting underyearlings of chinook (Oncorbynchus tshaweytscha) and coho (O.kisutch) salmon in the Big Qualicum River, British Columbia. Journal of the Fisheries Research Board of Canada $27: 1215-1224$.

Mains, E.M., and J.M. Smith. 1956. The distribution, size, time, and current preferences of seaward migrant chinook salmon in the Columbia and Snake Rivers. Washington Department of Fisheries, U.S. Army Corps of Engineers Contract number DA 35026-Eng-20571.

SAS Institute Inc. 1990. SAS Procedures Guide, Version 6, Third Edition, Cary, North Carolina: SAS Institute Inc.

Simms, C.W., and F.J. Ossiander. 1981. Migrations of juvenile chinook salmon and steelhead trout in the Snake River from 1973 to 1979, a research summary. Final report to U.S. Army Corps of Engineers, Contract DACW68-77-C-0038. Seattle, Washington.

Stein, R.A., P.E. Reamers, and J.D. Hall. 1972. Social interactions between juvenile coho (Oncorbynchuskisutch) and fall chinook (O.tshawytscha) in Sixes River, Oregon. Journal of the Fisheries Research Board of Canada 29:1737-1748.

Taylor, E.B. 1991. Behavioural interaction and habitat use in juvenile chinook, Oncorbynchustshareytscha, and coho, 0.kisutch, salmon. Animal Behaviour 42:729-744.

Venditti, D.A., and R.D. Garland. 1996. Nearshore movement and Feeding behaviors of juvenile fall chinook salmon in the Columbia River. Pages 80-98 in D.W. Rondorf and K.F. Tiffan, editors. Identification of the spawning, rearing, and migratory requirements of fall chinook salmon in the Columbia River Basin. Annual Report to Bonneville Power Administration, Contract DE-AI79-91BP21708, Portland, Oregon. 


\section{CHAF' TER FIVE}

\section{Osmoregulatory Performance and Migration Behavior of Subyearling Chinook Salmon}

\section{by}

K.F. Tiffan, R.D. Garland, and D.W. Rondorf

U.S. Geological Survey

Biological Resources Division

Northwest Biological Science Center

Columbia River Research Laboratory

Cook, Washington 98605, USA 


\section{Introduction}

Fall chinook salmon Oncorbynchustshawytscha in the Snake and Columbia rivers exhibit an ocean-type life history (Healy 1991). Fry emerge from spawning gravel in the spring, rear in nearshore areas for 2-3 months, then emigrate to the ocean during their first summer of life as subyearlings. Because the snake and Columbia rivers have largely been transformed into a series of reservoirs by hydropower development, emigration conditions during the summer are characterized by decreasing flows and increasing temperatures. These conditions often become unfavorable to cold-water adapted fish such as salmon and may negatively influence migratory behavior and survival. Juvenile salmon which emigrate earlier in the season may gain a survival advantage by emigrating under higher flows and cooler water temperatures.

Research conducted at McNary Dam from 1981 to 1983 determined that subyearling chinook salmon which emigrated earlier in the summer exhibited greater adult contribution than did later emigrants (Giorgi et al. 1990). No physical or biological factor could be isolated as a causal factor for this phenomenon even though a primary objective of the study was to examine the influence of flows on juvenile emigration and survival. Similar research that we conducted from 1991 to 1994 showed that early migrants usually had the fastest travel time from McNary to John Day Dam (Nelson et al. 1993a; Tiffan et al. 1994a, 1994b, 1996). Although the full complement of adult returns from this study is not in, preliminary data show that earlier emigrating fish have returned nearly twice as many adults as later migrants.

Currently causal evidence for differences in the migratory behavior and timing, and subsequent adult contribution of juvenile fall chinook salmon is lacking. Our 1995 work focuses on the physiological and migratory development of subyearling fall chinook salmon from nearshore rearing through emigration. It is intended to provide insight for interpreting observed differences in juvenile fall chinook salmon migratory behavior. The primary objective for this fifth year of study was to describe the physiological development of premigrants from the Hanford Reach of the Columbia River and run-at-large fish collected at McNary Dam by using seawater challenges and salinity preference tests. A second objective was to describe the seasonal development of migratory behavior at different water velocities in a series of laboratory experiments. 


\section{Methods}

\section{Seawater Challenges}

Premigrant subyearling chinook salmon from the Hanford Reach and actively emigrating subyearlings passing McNary Dam were subjected to 24-h seawater challenges to describe their osmoregulatory development. The general procedures of the seawater challenges followed those of Blackburn and Clarke (1987). Separate recirculating flow-through systems were used for challenged and control fish. The seawater system was composed of four 80-L plastic containers which drained into a sump reservoir and a pump that recirculated salt water from the sump to the plastic containers. The freshwater control system was identical to the seawater system except only two containers were used. Each container held $15 \mathrm{fish}$, which were allowed to acclimate for $24 \mathrm{~h}$ prior to being challenged. Chillers were placed in sump reservoirs to maintain water temperature at ambient river temperature up to $18.3^{\circ} \mathrm{C}$. Artificial sea salt was dissolved and added to the sump reservoir of the seawater system to infuse salt water into the tanks without handling or disturbing the fish. A desired salinity of 30 parts-per-thousand (ppt) was usually achieved within one hour. Unchallenged, control fish were maintained in fresh water.

At the end of a 24-h challenge, fish were immobilized in their tanks with $30 \mathrm{mg} / \mathrm{L} \mathrm{MS}-222$. Anesthetized fish were weighed to the nearest gram ( $\mathrm{g})$, measured to the nearest $1 \mathrm{~mm}$ fork length (FL), rinsed in fresh water, and their tails blotted dry before being severed. Blood was collected from the caudal artery in ammonium heparinized Natelson tubes, centrifuged, and the plasma immediately frozen in liquid nitrogen. Blood was pooled from three fish at a time to obtain an adequate plasma sample from small fish collected early in the season, and was carried out through the remainder of the season for consistency. Gill filaments were collected for determination of $\mathrm{Na}^{+}, \mathrm{K}^{+}$-ATPase activity. Blood plasma was analyzed for $\mathrm{Na}^{\prime}$ and $\mathrm{K}^{+}$by flame photometry and gill $\mathrm{Na}^{+}, \mathrm{K}^{+}$-ATPase activity was measured using a microassay (Schrock et al. 1994).

Both premigrant and actively emigrating subyearling chinook salmon were used in seawater challenges in 1995. Premigrants used in challenges were collected biweekly from the Hanford Reach from mid April to the end of June. Fish were collected with beach seines and transported in $80 \mathrm{~L}$ plastic containers to Cook, Washington. Oxygen was supplied to containers and water temperatures were maintained at $\pm 1^{\circ} \mathrm{C}$ of ambient river 
temperature. Actively emigrating subyearling chinook salmon were collected at the McNary Dam fish collection facility. Three separate challenges were conducted from late June to mid August to characterize the seawater adaptability of emigrants during the early, middle, late portions of the outmigration. Duplicate challenges were conducted concurrently at both Cook, Washington and McNary Dam to evaluate any effects due to transporting fish.

\section{Salinity Preference}

The salinity preference of subyearling fall chinook salmon was evaluated in a two-choice tank (Figure 1A) modified from Baggerman (1960). Each plywood tank was $93 \mathrm{~cm}$ long x $50 \mathrm{~cm}$ wide x $65 \mathrm{~cm}$ high. A $43 \mathrm{~cm}$ high sheet of plexiglass placed in the center of the tank divided it into two equal compartments. One side of the tank was made of plexiglass, which allowed both sides of the tank to viewed from the side. Valved inflow pipes were placed in the back corner of each side of the tank and extended to the bottom of the tank. The outlets of external, over-flow stand pipes were located on opposite ends of the tank and positioned to draw water from just below the level of the center divider. This allowed saline water to be infused into one side of the tank without spilling over into the other compartment. A freshwater bridge $15 \mathrm{~cm}$ deep over the center divider allowed fish to pass between the two sides of the tank. Aquarium tubing extending to different depths at the back of each side of the tank allowed water to be siphoned off for periodic salinity measurements.

Subyearling chinook salmon used in salinity preference tests were collected in the Hanford Reach of the Columbia River throughout the spring and then at McNary Dam during the summer. Testing was conducted using a pair of tanks; one saline gradient tank and one freshwater control tank. The tank and compartment that received salt water was randomly determined for each test. Six replicate tests were run per week using new fish in each test. Ten fish were placed in each tank, five in each compartment, and were allowed an acclimation period of $1 \mathrm{~h}$ in fresh water, which allowed fish to explore the tank. After acclimation, one side of one tank was infused with 20 ppt salt water until the outflow salinity equaled inflow salinity. At this point, the inflow was stopped and behavior in each tank was recorded using separate video systems for a period of $2 \mathrm{~h}$.

Fish behavior in salinity preference tanks was determined using a video camera set to view the plexiglass side of the tank so fish positions could be monitored. Images were sent to a remote VCR operated in 12-h time lapse. Overhead lighting was 


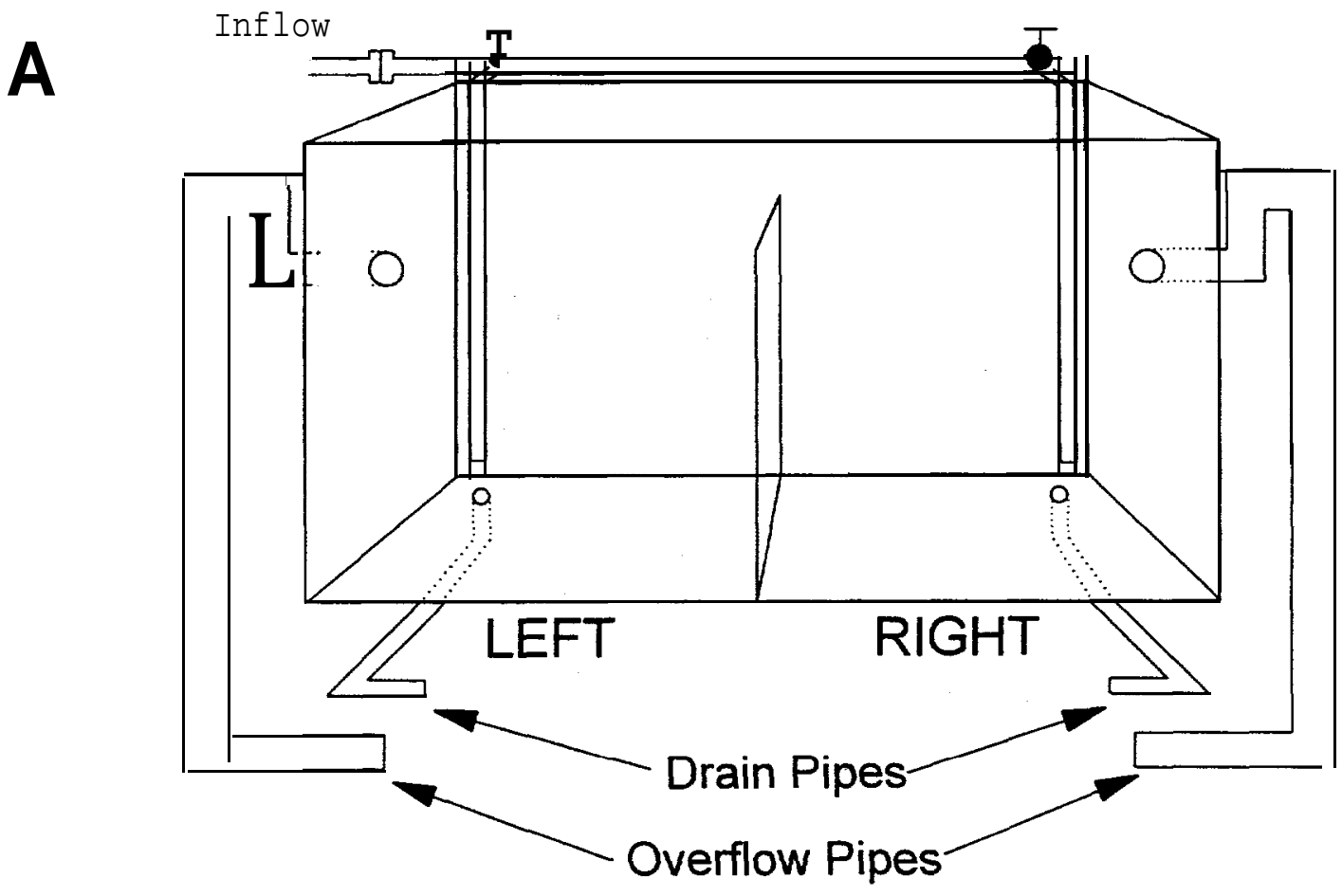

B

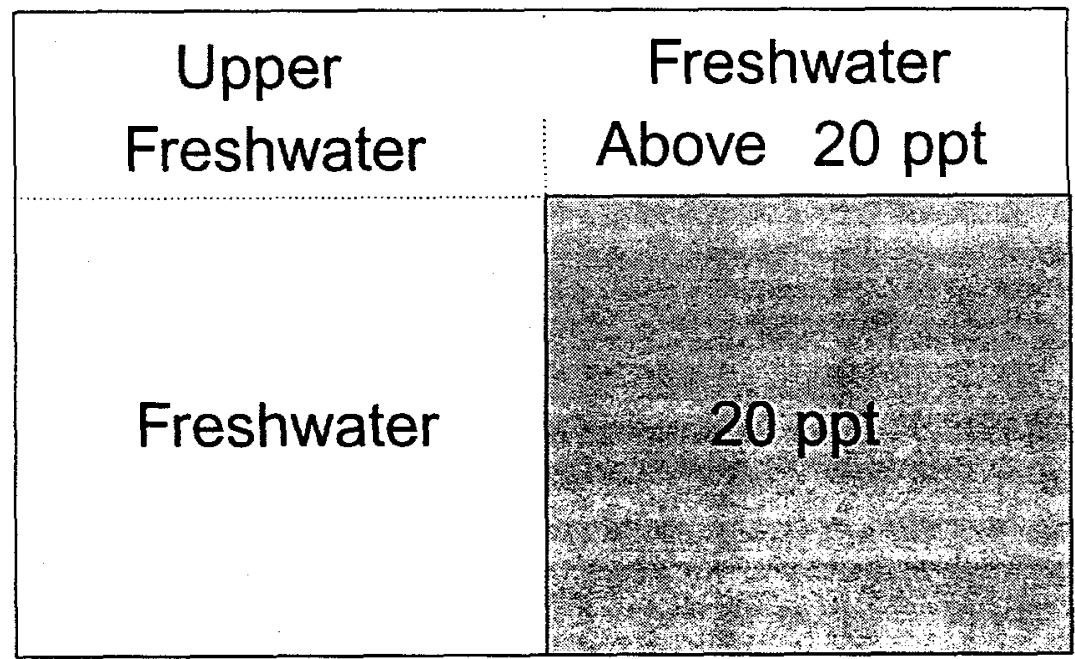

Front View

Figure 1. -Schematic of one of the two salinity preference tanks used in 1995 (A), and the arbitrary divisions of the tank used for video analysis of fish locations during tests (B). 
provided by $60 \mathrm{~W}$ incandescent bulbs over each tank. The entire testing arena was surrounded by a dark canvas curtain to minimize disturbance.

Video tapes were analyzed by making counts of fish locations in four arbitrary divisions of the tank (Figure 1B). Observations were made every three minutes throughout the test for a total of 50 observations, and the number of fish observed was summed for each location. Chi-square analyses were performed to compare the distribution of fish on the salt and freshwater sides of each tank to a random distribution for each test (Zar 1984). The following rules were used to determine if there was a preference for salt or fresh water in the gradient tank. If the null hypothesis that distributions were random in each gradient and control tank for a given test was not rejected at $\boldsymbol{\alpha}<0.05$, then preference could not be determined. If the null hypothesis was rejected in the gradient tank, but not in the control tank, then preference was assigned to the side of the gradient tank which contained the most observations. If the null hypothesis was rejected in both gradient and control tanks, then a preference for a particular side of the gradient tank could only be determined if the side containing the most observations did not correspond to that of the control tank. If the most observations occurred on the same sides of both gradient and control tanks, then preference could not be determined.

In addition to statistical determination of salinity preference, test results within a given week were pooled and displayed graphically. The average number of fish on the saltwater sides of the gradient tanks, or corresponding sides of the control tanks, were calculated for the saltwater layer and for the freshwater layer above the salt water and converted to percentages.

\section{Migration Experiments}

Movement behavior was studied in a compartmentalized, fluvial tank to determine the seasonal changes in migratory disposition of both premigrant and actively emigrating subyearling fall chinook salmon. Tests were conducted biweekly from May through August using fish collected from the Hanford Reach and from McNary Dam in both 1994 and 1995. Two tanks were used to provide fish with a series of up and downstream choices under different water velocities and light conditions, Each tank was $4.8 \mathrm{~m}$ long and was divided down the middle by a partition

(Figure 2). Additional partitions were set perpendicular to the center partition to divide the tank into 16 compartments measuring $0.5 \mathrm{~m}$ wide $\times 0.6 \mathrm{~m}$ long $\times 0.6 \mathrm{~m}$ deep. Holes $(0.1 \mathrm{~m}$ 


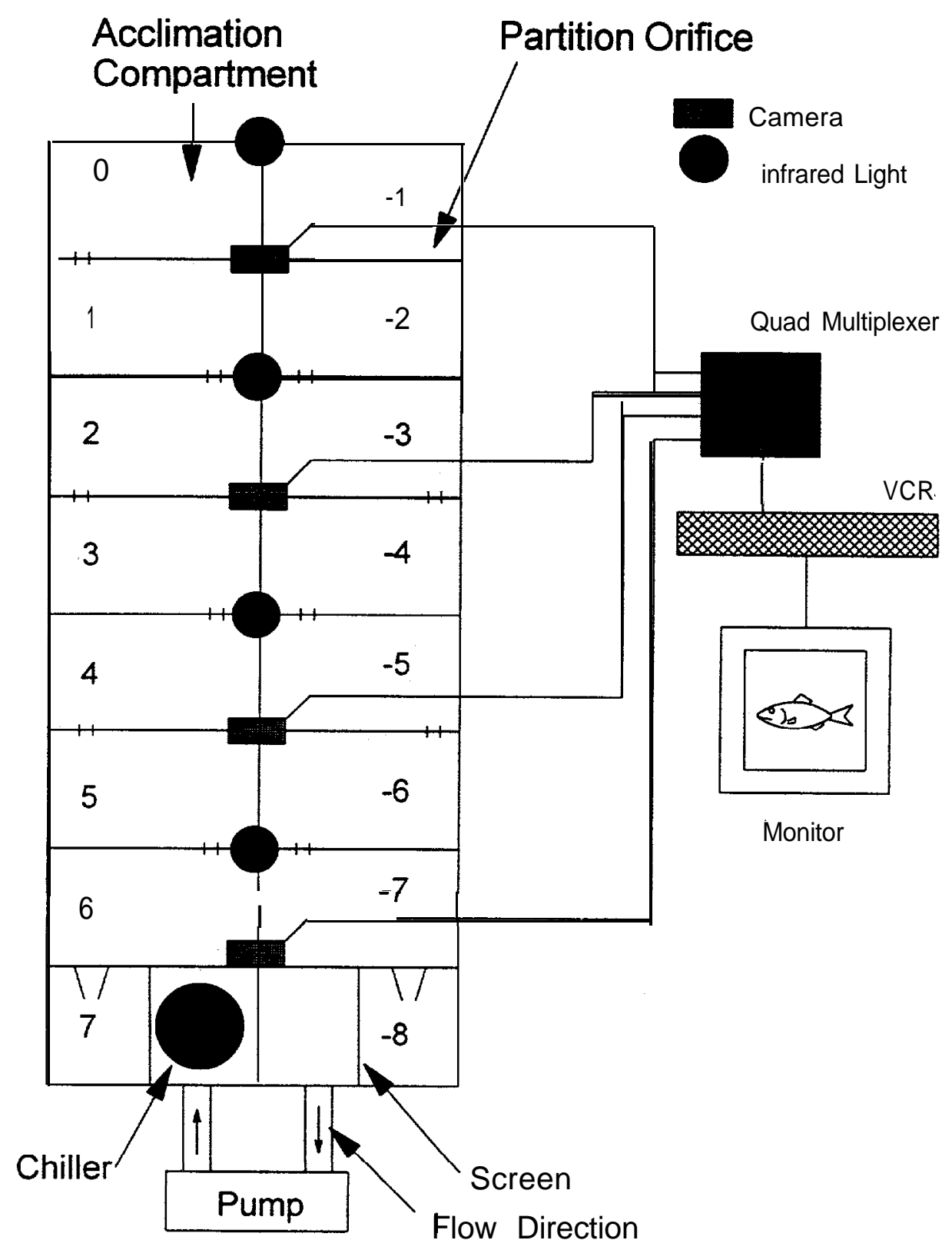

Figure 2. -Schematic of the tank, with compartment numbering convention, used to test migration behavior of subyearling chinook salmon in 1995. 
diameter) were cut in each compartment partition $0.2 \mathrm{~m}$ from the bottom and were staggered as shown in Figure 2 to increase the complexity of passage through the tank. Cone traps were set in the farthest up and downstream compartments to trap fish reaching the ends of the tank. A pump circulated water through the tank and a chiller maintained the water at ambient river temperature. Water depth in each tank was $0.4 \mathrm{~m}$ and velocities of $0,15,30$, or $45 \mathrm{~cm} / \mathrm{s}$ were maintained at each partition hole by adjusting a valve plumbed between the pump and the tank. Daytime tests were usually conducted from 0800 to 1600 hours while nighttime tests were run from 2000 to 0400 hours the next day.

Fish behavior was monitored remotely using video equipment. Four overhead video cameras were used to view all compartments during a test (Figure 2). The use of a quad unit and VCR allowed images from all four cameras to be recorded simultaneously onto one video tape. Nighttime illumination was provided using infrared lights.

Tests were begun by placing screens over the partition holes of the acclimation compartment and introducing 10 fish. Placing fish in this compartment allowed seven upstream and eight downstream choices to be made before reaching the ends of the tank. Fish were allowed a 4-h acclimation period after which the screens were removed and the fish were allowed to move freely about the tank. Fish were then videotaped in 12-h time lapse mode for $4 \mathrm{~h}$. At the end of each test, fish locations were recorded and the fish were either removed and weighed and measured or else were left in the tank if they were to be used again.

A completely randomized design was used to evaluate movement behavior under all combinations of velocity and light. The 45 $\mathrm{cm} / \mathrm{s}$ velocity was only used during the daytime when sufficient numbers of fish could be obtained. New groups of fish were tested at each water velocity in each tank. Each group of fish was evaluated twice at a particular velocity; once under light conditions and once in darkness. The order test velocities were randomly determined each week. To avoid potential bias from starting replicate tests of a given velocity under the same light condition, the starting light condition between the two tanks was varied. An example of this is shown in the following diagram: 


\begin{tabular}{|c|c|c|c|c|c|c|c|c|}
\hline \multirow[b]{2}{*}{ Tank } & \multicolumn{2}{|c|}{ Tuesday } & \multicolumn{2}{|c|}{ Wednesday } & \multicolumn{2}{|c|}{ Thursday } & \multicolumn{2}{|c|}{ Friday } \\
\hline & Day & Night & Day & Night & Day & Night & Day & Night \\
\hline 1 & $30^{\prime}$ & 30 & 0 & 0 & 15 & 15 & 45 & \\
\hline 2 & 45 & 15 & 15 & 30 & 30 & 0 & 0 & \\
\hline
\end{tabular}

Fish were arbitrarily grouped according to their migratory status for analyses. Fish obtained in nearshore areas of the Hanford Reach through mid June were termed premigrants. Fish collected at McNary Dam from the end of June through August were termed migrants.

Tests were analyzed to obtain a net movement score, mean time to an up or downstream trap, and activity levels. Scores were assigned to each fish based on the compartment it was in at the end of the test. The acclimation compartment served as a reference and was assigned a value of 0 . Then each compartment up and downstream were numbered sequentially, with downstream compartments being negative. Therefore, the higher the score for a given fish, the further upstream it traveled, and conversely, the lower the score, the further downstream it was at the end of the test. Scores were summed to produce a net movement score for the test.

Videotapes were scanned for the times fish entered the up and downstream traps to determine the rate of movement to the ends of the tank. Mean movement times to traps were calculated for fish at each water velocity during each week of testing. The proportion of fish entering the traps was also calculated. Day and night tests were combined within each velocity to simplify analysis. Linear regression and correlation analyses were conducted to examine the relationships between movement rate and proportion trapped and date of testing (SAS Institute 1990).

To determine how final scores and movement rates were related to fish behavior during each test, the activity levels of fish were measured by counting the number of partitions that were passed within subsampled time blocks. Subsampled blocks were 15 min long and one block was sampled for each hour of testing for a maximum of four blocks for a 4-h test. Activities from the blocks were summed and adjusted for the number of fish in the traps and were expressed as the number of partitions passed per fish per hour; no attempt was made to distinguish individual fish. 


\section{Results}

\section{Seawater Challenges}

Mortality and plasma sodium levels of subyearling fall chinook salmon in seawater challenges showed similar decreases as fish developed from premigrant into migrants (Figure 3). Mortality was high for premigrants in 1995 and did not drop below $10 \%$ until active migrants were challenged beginning in late June. The only mortality in control fish occurred on June 1 and was 3.3\%. Plasma sodium levels of seawater challenged fish decreased until mid July and then rose slightly in mid August (Figure 3). Fish were osmoregulatory competent by the end of June when they were able to maintain plasma sodium near or below $165 \mathrm{mmol} / \mathrm{L}$ (Clarke and Shelbourn 1985). These fish were active migrants collected at McNary Dam and challenged at Cook, Washington. Migrants challenged at McNary Dam had plasma sodium levels near or higher than $165 \mathrm{mmol} / \mathrm{L}$ (Figure 3), which indicated that fish had difficulty osmoregulating. High plasma sodium values were not observed in active migrants challenged at McNary Dam in 1992 and 1993. Plasma sodium values of seawater challenged fish were all significantly different than control fish values.

Condition factors of premigrants challenged in salt water were significantly lower than those of control fish until mid June suggesting that fish in salt water were having difficulty osmoregulating (Figure 4). Condition factor was used because water loss in a hyperosmotic environment can cause reduction of both length and weight (Zaugg and Beckman 1990). Once fish attained a size of about $60 \mathrm{~mm}$ fork length, condition factors were not significantly different (Figure 4).

Gill ATPase activities of seawater challenged and control fish at Cook, Washington were similar, except for June 1 and June 14, and followed a trend of increasing activity with time until the end of June (Figure 5). Activities then decreased through mid August. This trend was also observed in 1994. The ATPase activities of fish challenged at McNary Dam showed a peak in mid July with a decrease in mid August.

\section{Salinity Preference}

Subyearling fall chinook salmon showed the greatest preference for salt water from late June to mid July (Table 1; Figure 6). Fresh water was generally less preferred than salt water, especially during mid July when no fish showed a 

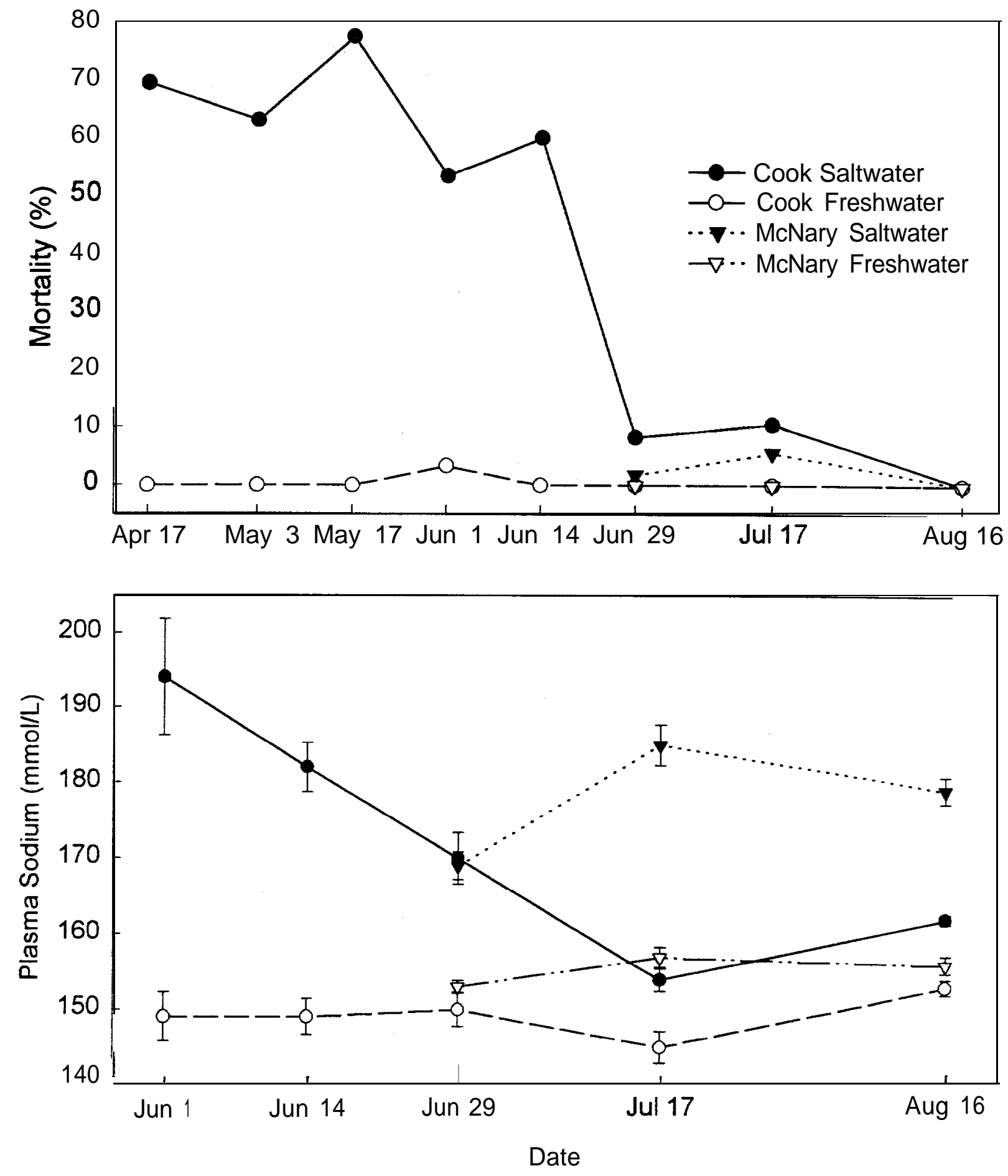

Figure 3.-Percent mortality and plasma sodium of subyearling fall chinook salmon subjected to $24-\mathrm{h}$ seawater challenges at Cook, WA and McNary Dam in 1995. 

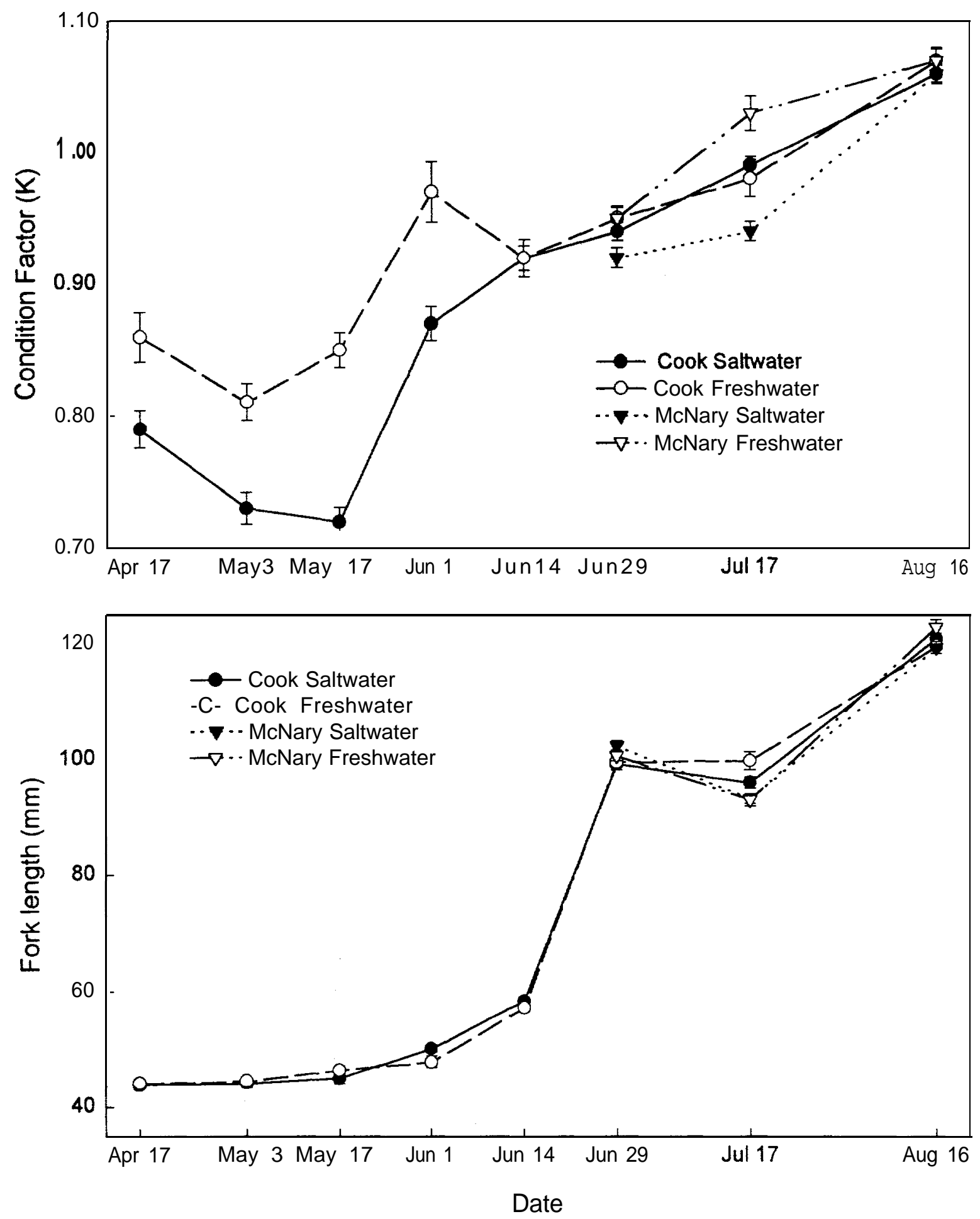

Figure 4. -Condition factor ( $K$ ) and fork length of subyearling fall chinook salmon subjected to $24-\mathrm{h}$ seawater challenges at Cook, WA and McNary Dam, 1995. 


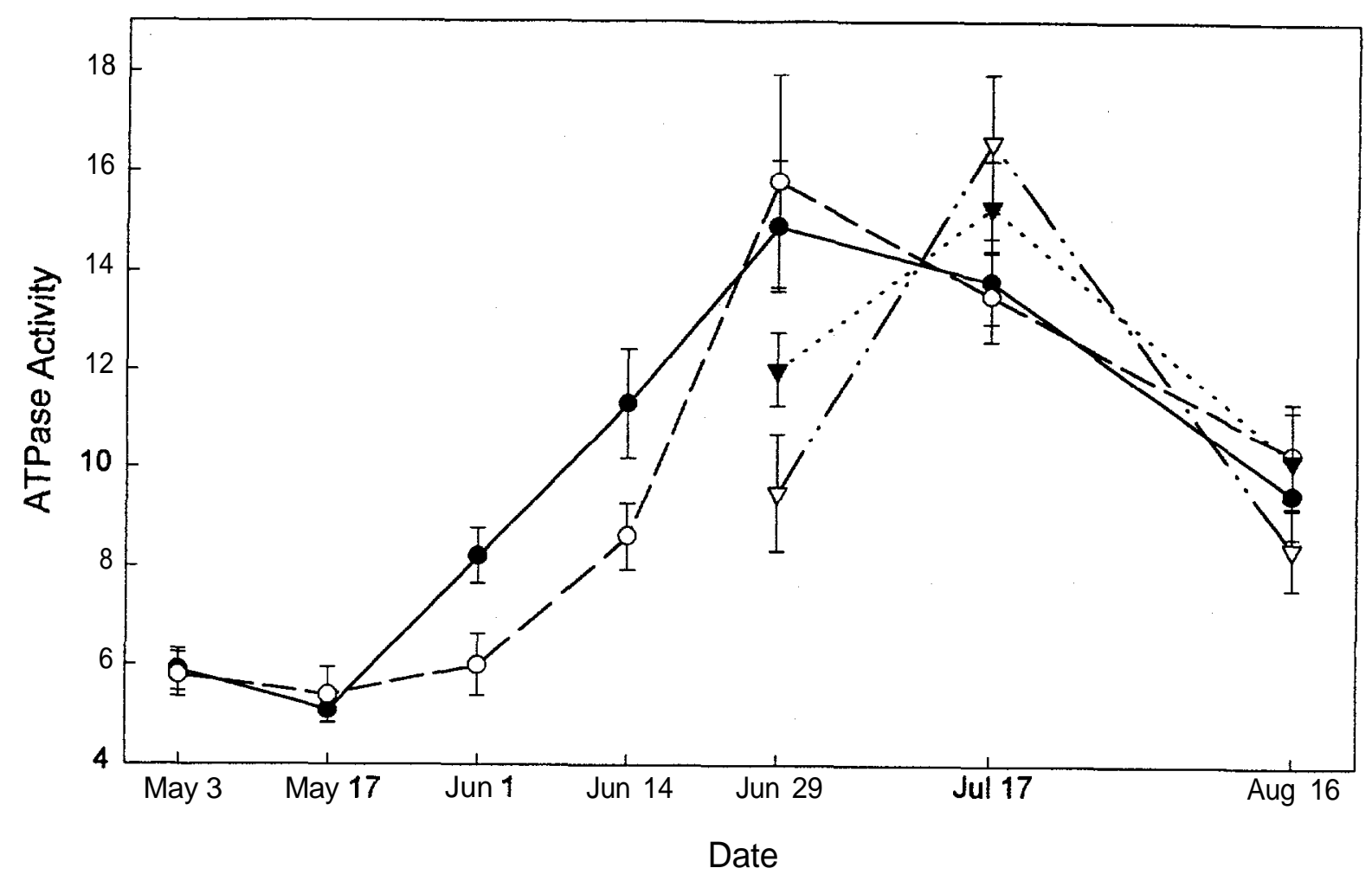

$\begin{array}{ll}\rightarrow-\text { Cook Saltwater } & \cdots \\ \rightarrow-\text { Cook Freshwater } & \rightarrow \cdot \cdot \text { McNary Saltwater }\end{array}$

Figure 5.-Gill ATPase activity of subyearling fall chinook salmon subjected to $24-\mathrm{h}$ seawater challenges at Cook, WA and McNary Dam in 1995. 
Table 1.-The number of salinity preference tests in which subyearling fall chinook salmon showed a preference for the saltwater side of the gradient tank, freshwater side of the gradient tank, or in which preference could not be determined in 1995. Preferences were determined by Chi-square analyses and are summarized by week of testing.

\begin{tabular}{|c|c|c|c|c|}
\hline Week & $\begin{array}{l}\text { Preference for } \\
\text { saltwater side }\end{array}$ & $\begin{array}{l}\text { Preference } \\
\text { freshwater }\end{array}$ & $\begin{array}{l}\text { for } \\
\text { side }\end{array}$ & $\begin{array}{c}\text { Preference } \\
\text { undeterminable }\end{array}$ \\
\hline May 10 & 1 & 0 & & 3 \\
\hline May 23 & 1 & 1 & & 4 \\
\hline June 6 & 3 & 2 & & 1 \\
\hline June 20 & 3 & 1 & & 3 \\
\hline July 12 & 4 & 0 & & 2 \\
\hline August 1 & 2 & 1 & & 2 \\
\hline August 21 & 3 & 1 & & 2 \\
\hline
\end{tabular}



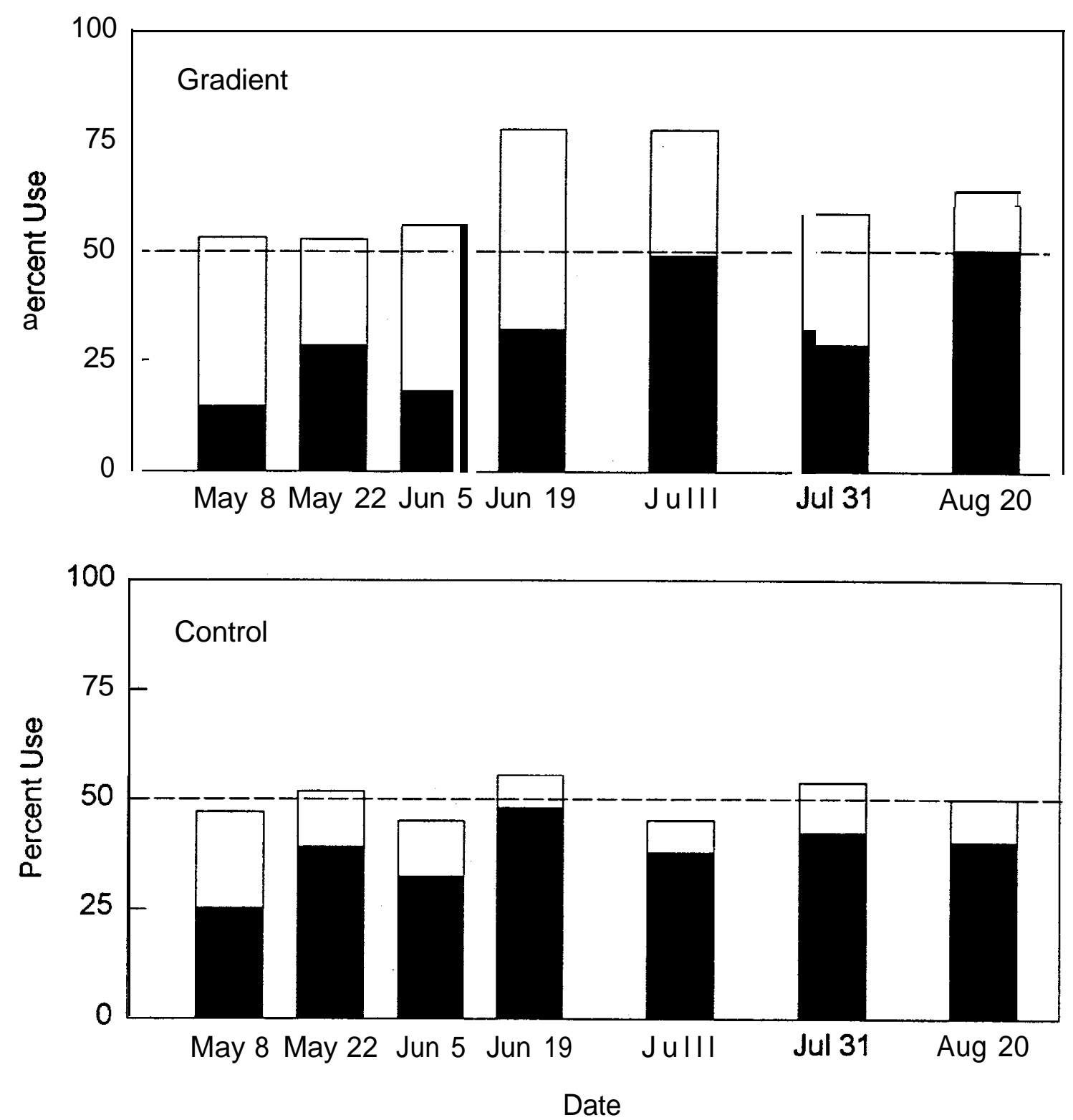

SALT ONLY ABOVE SALT

Figure 6. -Percent useage of saline and fresh water on the saline side of salinity preference tanks by subyearling fall chinook salmon in 1995. Only the gradient tank contained salt water. The control tank contained only fresh water so the bars show useage of areas that corresponded to the salt water side of the gradient tank. See text for additional detail on tank design. 
preference for fresh water. Many tests were conducted in which a preference for salt or fresh water could not be determined.

Pooling tests by week included all the variability displayed by gradient and control fish, and more clearly showed fish use of the saltwater side of the test tank, or corresponding side of the control tank (Figure 6). Fish observed on the saltwater side of the gradient tank primarily used the freshwater layer above the salt water, which accounted for only 25\% of the available volume. Exceptions to this occurred in mid July and late August when half of the fish observed were found in the saltwater layer. Fish observed in the control tank used each side of the tank equally throughout the season. Vertical distribution of control fish was generally proportional to the available volume of each layer with perhaps a slight bias toward the corresponding saltwater layer.

Migration Experiments

Movement scores of premigrant subyearling chinook salmon in migration tests were influenced by water velocity in both 1994 and 1995. Fish exposed to $0 \mathrm{~cm} / \mathrm{s}$ water velocity under both light and dark conditions exhibited net movement scores near 0 (Figure 7). In contrast, net movement scores were considerably lower (in a downstream direction) in tests conducted when water velocities were present. Premigrants tested during the day in 1995 showed a direct increase in downstream movement with increasing water velocity, but in 1994, daytime scores were lowest at $15 \mathrm{~cm} / \mathrm{s}$ velocity and remained low at 30 and $45 \mathrm{~cm} / \mathrm{s}$. Scores of premigrants tested at night were similar between years except at the $30 \mathrm{~cm} / \mathrm{s}$ velocity. At this velocity, fish tested in 1994 had higher scores than fish tested in 1995.

Migrants generally had higher net movement scores, indicating less downstream movement, than premigrants in both years when velocity was present (Figure 7). Although movement was in a downstream direction, there was no apparent relationship to water velocity during daytime tests. At night, a slight increase in downstream movement as water velocity increased was observed in both years.

The average time for fish to move to the downstream trap increased with date at all velocities in both years (Figures 89). The only exception was for fish tested at $0 \mathrm{~cm} / \mathrm{s}$ in 1994 . The strength of the linear relationship between time to trap and date increased with water velocity in 1994, but the reverse was true in 1995 (Table 2). These two variables were significantly correlated at velocities of 15, 30 , and $45 \mathrm{~cm} / \mathrm{s}$ in 1994 , and for 15 and $30 \mathrm{~cm} / \mathrm{s}$ in 1995. There was also a corresponding decrease 

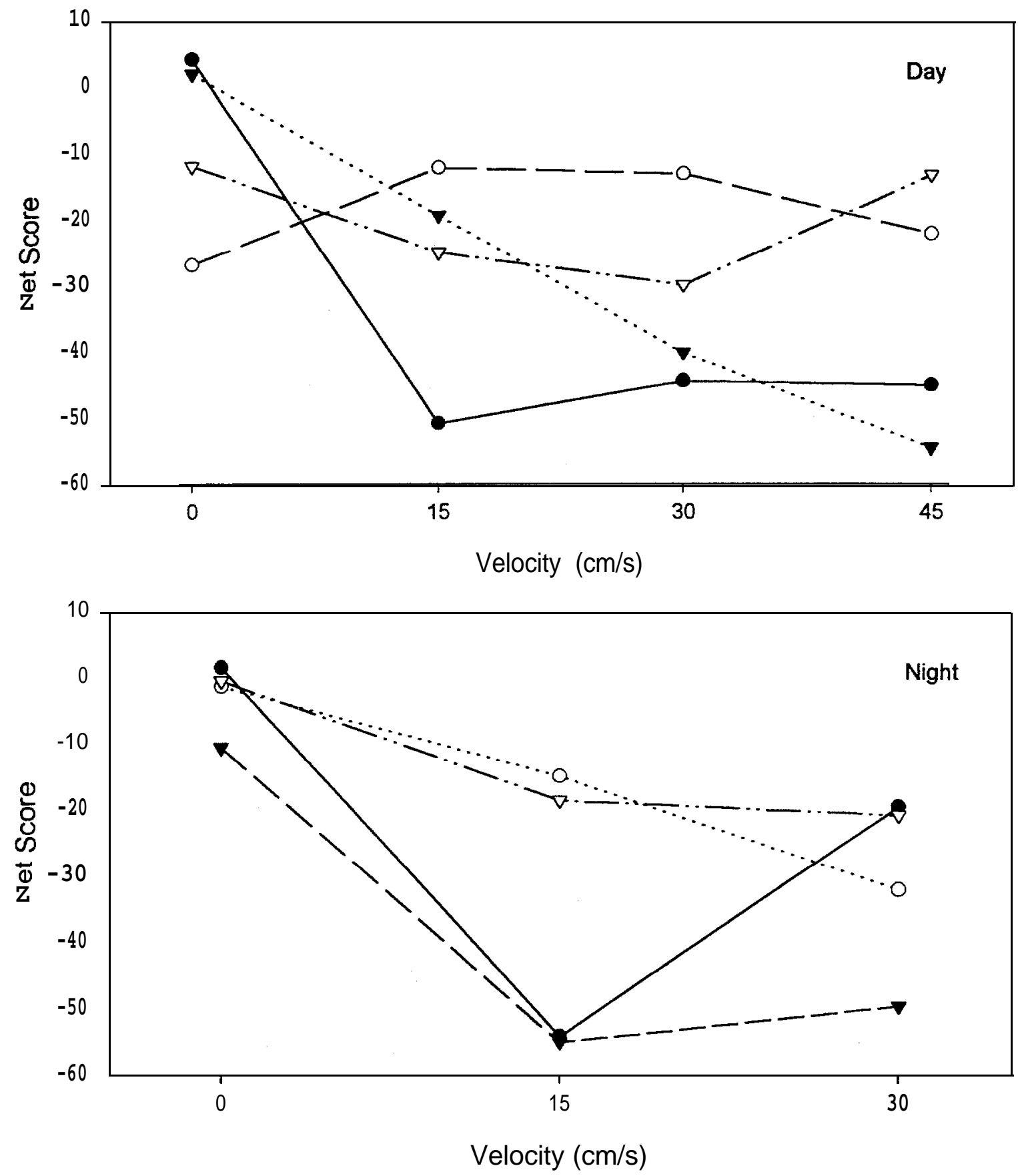

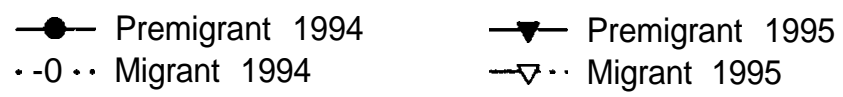

Figure 7. -Daytime and nighttime net movement scores of premigrant and migrant subyearling fall chinook salmon tested at different velocities in migration tanks in 1994 and 1995. 

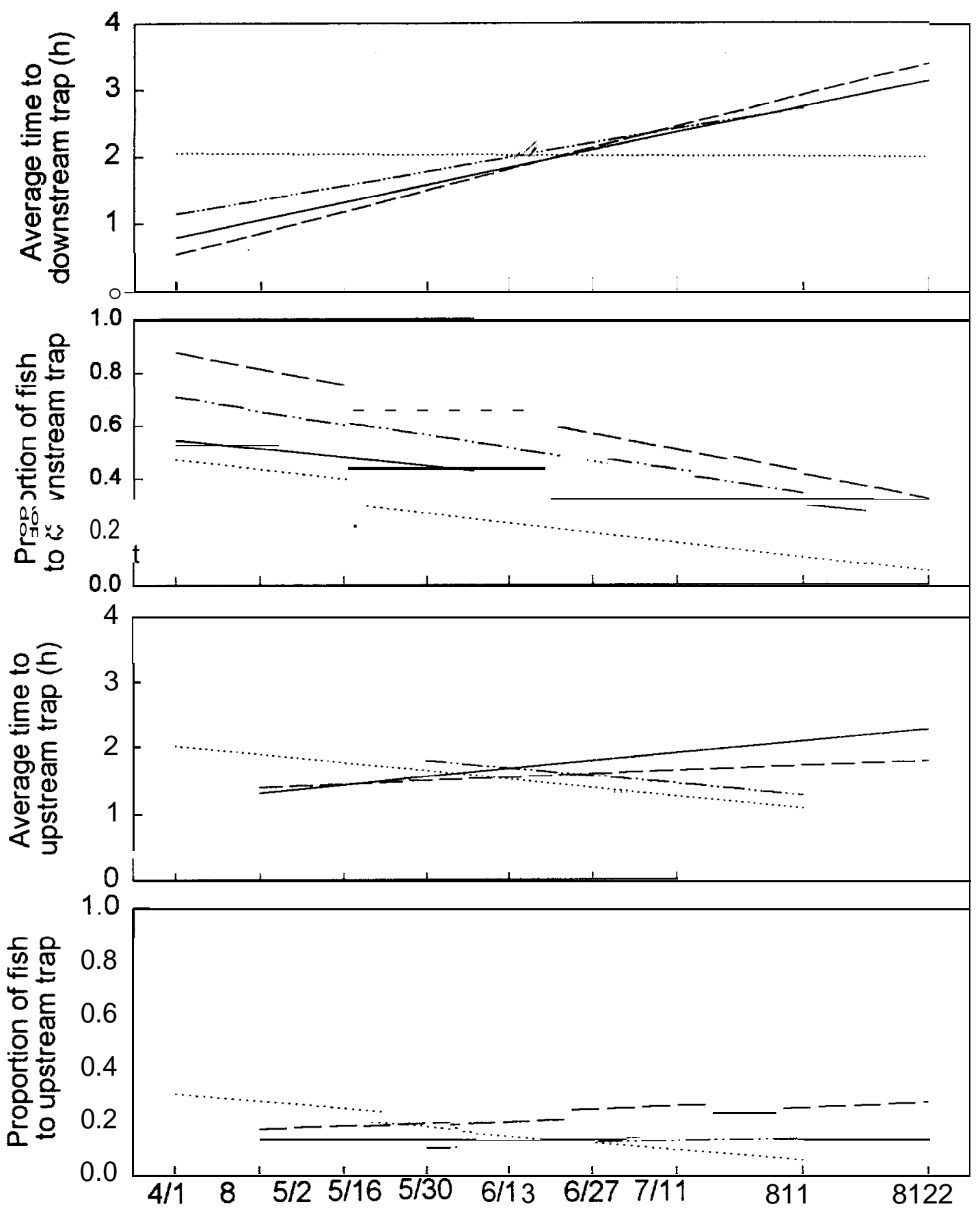

Date

$$
0 \mathrm{~cm} / \mathrm{s}--15 \mathrm{~cm} / \mathrm{s}-30 \mathrm{~cm} / \mathrm{s}--45 \mathrm{~cm} / \mathrm{s}
$$

Figure 8-Regressions of average rates and proportions of subyearling fall chinook salmon to the up and downstream traps of migration tanks against date under different velocities in 1994. 


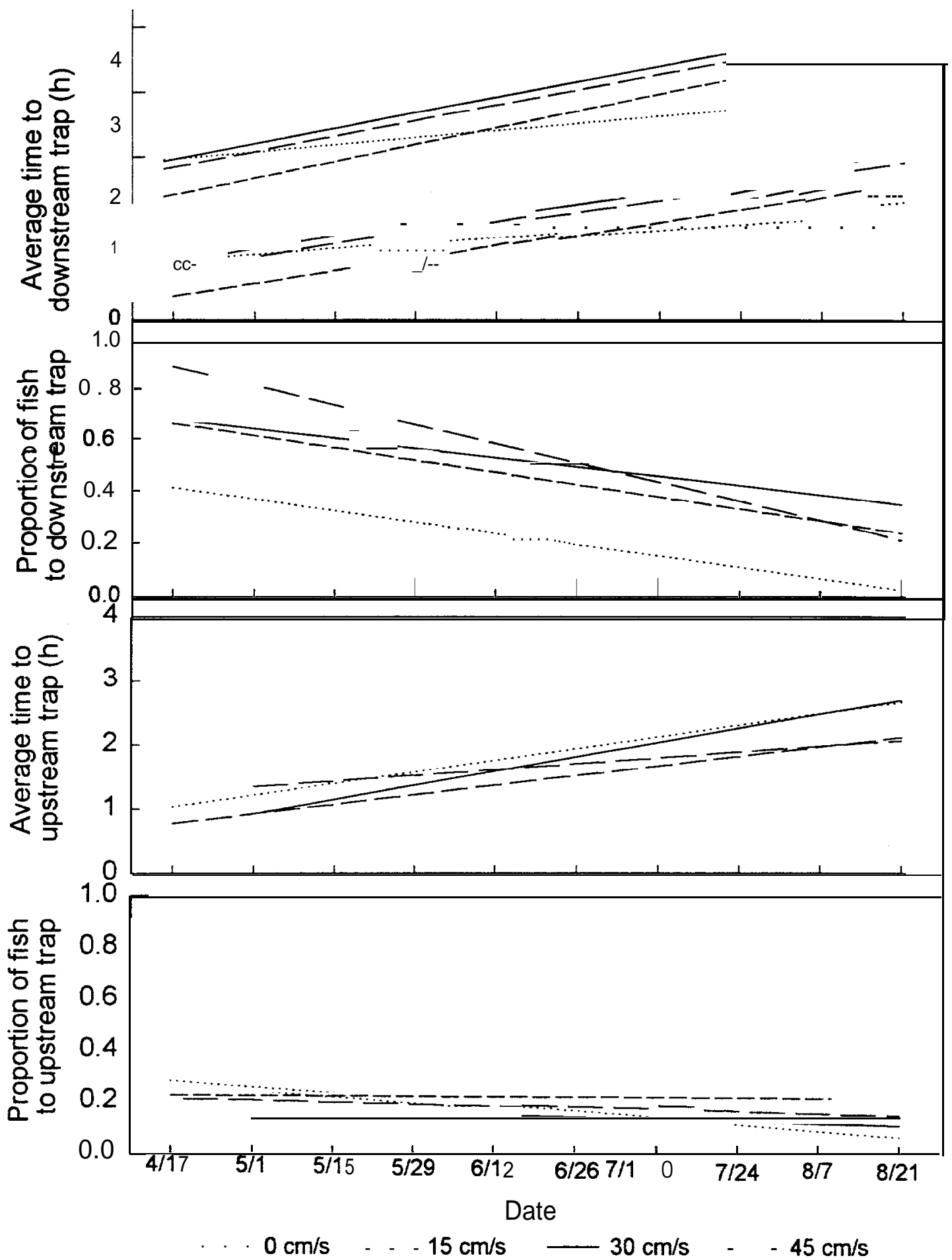

Figure 9. -Regressions of average rates and proportions of subyearling fall chinook salmon to the up and downstream traps of migration tanks against date under different velocities in 1995 . 
Table 2 .-Coefficients of determination $\left(\mathrm{R}^{2}\right)$ and correlation ( $r$ ) from linear regression and correlation analysis of the rates and proportions of trapped fish against date of fish tested in migration experiments in 1994 and 1995. Asterisks indicate significance at $\alpha \leq 0.05$.

\begin{tabular}{|c|c|c|c|c|c|c|}
\hline \multirow[b]{2}{*}{ Year } & \multirow{2}{*}{\multicolumn{2}{|c|}{ Velocity }} & \multirow{2}{*}{$\frac{\text { Rate to }}{\mathrm{R}^{2}}$} & \multirow{2}{*}{$\frac{\text { vs. Date }}{r}$} & \multicolumn{2}{|c|}{$\begin{array}{c}\text { Proportion Trapped } \\
\text { vs. Date }\end{array}$} \\
\hline & & & & & $\mathrm{R}^{2}$ & r \\
\hline \multicolumn{7}{|c|}{ Downstream } \\
\hline 1994 & 0 & $\mathrm{~cm} / \mathrm{s}$ & 0.0049 & -0.07 & 0.3023 & -0.5498 \\
\hline 1994 & 15 & $\mathrm{~cm} / \mathrm{s}$ & 0.5594 & $0.7480 * *$ & 0.2661 & -0.5158 \\
\hline 1994 & 30 & $\mathrm{~cm} / \mathrm{s}$ & 0.6922 & $0.8320 * *$ & 0.1682 & -0.4102 \\
\hline 1994 & 45 & $\mathrm{~cm} / \mathrm{s}$ & 0.8776 & $0.9368 * *$ & 0.7035 & -0.8388 \\
\hline 1995 & 0 & $\mathrm{~cm} / \mathrm{s}$ & 0.1954 & 0.4420 & 0.5284 & $-0.7269 * \star$ \\
\hline 1995 & 15 & $\mathrm{~cm} / \mathrm{s}$ & 0.8010 & $0.8950 * *$ & 0.3857 & -0.6210 \\
\hline 1995 & 30 & $\mathrm{~cm} / \mathrm{s}$ & 0.5851 & $0.7649 * *$ & 0.6002 & $-0.7747 * *$ \\
\hline 1995 & 45 & $\mathrm{~cm} / \mathrm{s}$ & 0.4569 & 0.6760 & 0.7467 & -0.8641 \\
\hline \multicolumn{7}{|c|}{ Upstream } \\
\hline 1994 & 0 & $\mathrm{~cm} / \mathrm{s}$ & 0.1517 & -0.3896 & 0.6279 & $-0.7924 * *$ \\
\hline 1994 & 15 & $\mathrm{~cm} / \mathrm{s}$ & 0.4810 & -0.6935 & 0.0321 & 0.1790 \\
\hline 1994 & 30 & $\mathrm{~cm} / \mathrm{s}$ & 0.2107 & 0.4591 & 0.3371 & 0.5806 \\
\hline 1994 & 45 & $\mathrm{~cm} / \mathrm{s}$ & 0.5222 & 0.7226 & 0.2307 & 0.4803 \\
\hline 1995 & 0 & $\mathrm{~cm} / \mathrm{s}$ & 0.4643 & 0.6814 & 0.3349 & -0.5787 \\
\hline 1995 & 15 & $\mathrm{~cm} / \mathrm{s}$ & 0.2921 & 0.5404 & 0.0007 & -0.0272 \\
\hline 1995 & 30 & $\mathrm{~cm} / \mathrm{s}$ & 0.3527 & 0.5938 & 0.1140 & -0.3377 \\
\hline 1995 & 45 & $\mathrm{~cm} / \mathrm{s}$ & 0.0543 & 0.2329 & 0.0517 & -0.2273 \\
\hline
\end{tabular}


in the proportion of fish that made it to the downstream trap as the season progressed in both years (Figures 8-9).

The time for fish to move to the upstream trap was variable in 1994 as was the proportion of fish that were trapped. Time decreased for 0 and $15 \mathrm{~cm} / \mathrm{s}$ velocities and increased for 30 and $45 \mathrm{~cm} / \mathrm{s}$ as the season progressed. The proportion trapped decreased over the season for $0 \mathrm{~cm} / \mathrm{s}$ velocity, but increased at the remaining velocities. In 1995, there was an increase in travel time to the upstream trap over the season at all velocities tested, but the proportion of fish that were trapped remained fairly steady for all velocities (Figure 9). In general, the proportion of fish that made it to the upstream trap was much lower than the proportion in the downstream trap.

Activity levels of premigrants and migrants were similar during daytime tests in both years, and showed a general decrease as water velocity increased (Figure 10). A relationship between nighttime activity and water velocity was not apparent, but activities of both premigrants and migrants was lowest at $30 \mathrm{~cm} / \mathrm{s}$ water velocity (Figure 10).

The most striking differences in activity levels were between day and night tests. Daytime activities were significantly higher than nighttime activity levels. Although nighttime activities were very low, movement scores were often highly negative indicating that at night fish moved downstream more directly.

\section{Discussion}

The development of osmoregulatory competence in subyearling chinook salmon is partly a function of fish size (Hoar 1976) and growth rate (Wagner et al. 1969). Premigrants rearing in the Hanford Reach grow rapidly and their increase in gill ATPase activity with size occurs concurrently with their osmoregulatory development; Although mortality remained high for fish challenged from the Hanford Reach in 1995, their plasma sodium levels did follow a decreasing trend with increasing fish size, ATPase activity, and date. Subyearling chinook salmon did not demonstrate osmoregulatory competence until they were collected at McNary Dam in 1995, which is consistent with challenge data collected from 1992-1994. Clarke and Shelbourn (1985) reported that subyearling chinook salmon did not obtain optimum sodium regulation in seawater until they reached a weight of 5-6 $\mathrm{g}$. This generally corresponds to a 75-85 $\mathrm{mm}$ fish in the Hanford 

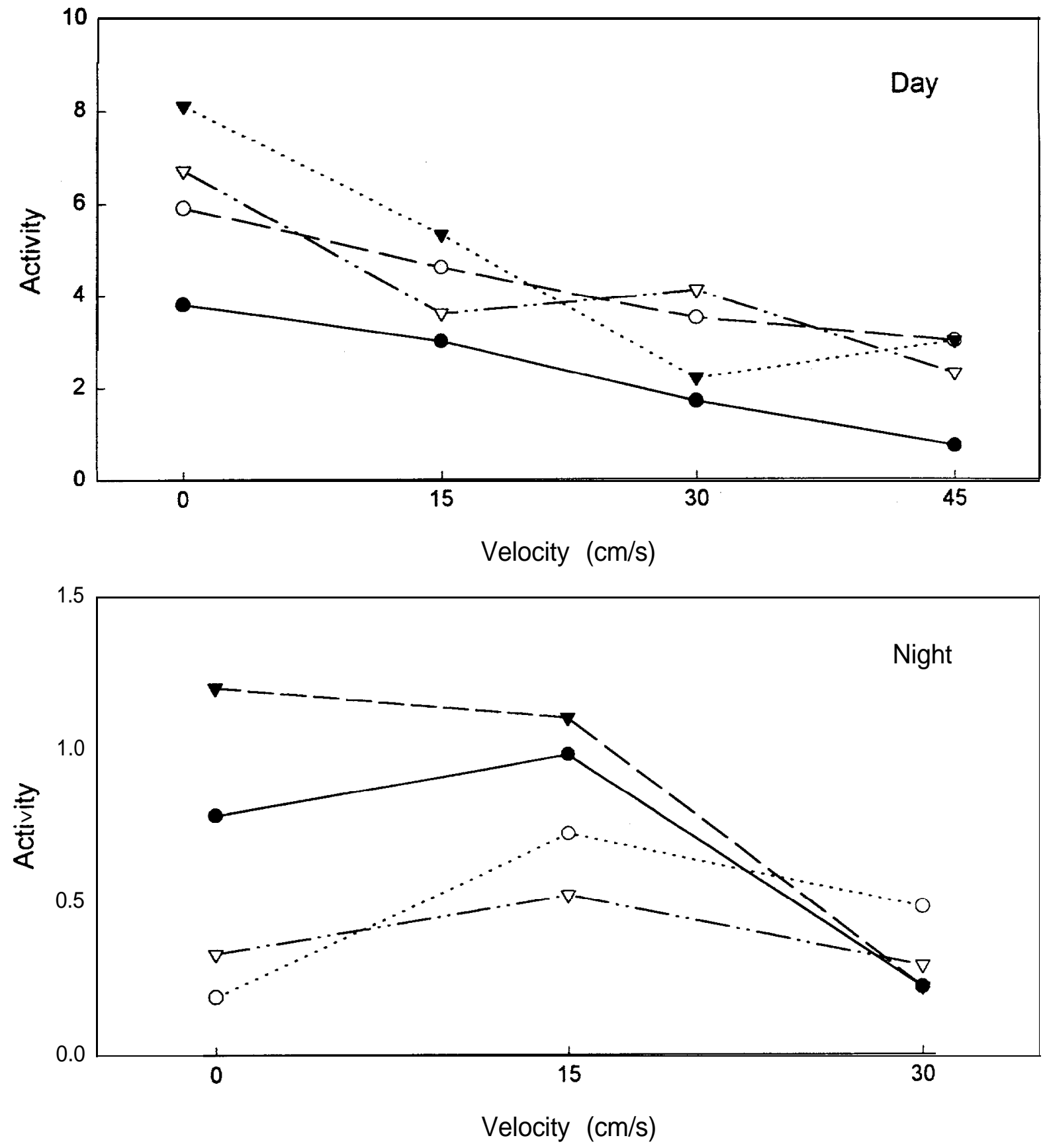

$\longrightarrow$ Premigrant, $1994 \longrightarrow$ Premigrant, 1995

. O.. Migrant, $1994 \quad \rightarrow$.. Migrant, 1995

Figure 10. -Daytime and nighttime activities of subyearling premigrant and migrant fall chinook salmon tested at different velocities in migration tanks in 1994 and 1995. 
Reach. Fish larger than about $70 \mathrm{~mm}$ were not abundant in nearshore areas of the Hanford Reach and probably had moved off shore to begin emigrating seaward. It appears that development of seawater tolerance and increasing gill ATPase activity accompanies initiation of emigration in subyearling chinook salmon.

Emigrating subyearlings that were challenged at McNary Dam in 1995 did not perform as well in seawater challenges as fish challenged at our lab in Cook, Washington. One explanation for this is that the new juvenile fish collection facility at McNary Dam may be more stressful to fish than the old one, and fish may need more time to recover from collection stress before they are suitable test animals. Fish that were challenged at McNary Dam were collected and the 24-h acclimation period was begun immediately. In contrast, the acclimation period for fish that were transported to Cook did not begin until the following morning, which increased their recovery time. Stress can cause an influx of ions from a hyperosmotic environment and a loss of water from the fish (Mazeaud et al. 1977), and may explain the high plasma sodium values in McNary Dam challenged subyearling chinook salmon.

Subyearling chinook salmon showed the greatest preference for saline water in late June and early July when fish were beginning their seaward emigration. Gill ATPase activities were also peaking at this time and may have influenced fish preference for saline water. The fact that fish were often observed above the saline layer even though it represented a fraction of the available space may be the result of the short duration of the tests and fish needing more time to adapt to the saline layer. In the estuary, fish have more time and are exposed to shallower salinity gradients, which facilitate transition to sea water, than what was represented in these tests. McInerney (1963) proposed that salinity preference may be used to guide fish emigrating through the estuary to the ocean. Whether salinity preference is a cue for seaward emigration in freshwater subyearling chinook salmon is unknown. However, peak salinity preference did occur when fish were actively smolting and beginning their seaward migration, and may therefore serve as an indicator of migratory disposition (Baggerman 1960).

To date it is unclear how water velocity influences initiation of downstream migration and travel time of subyearling chinook salmon. Unlike the swimming trials conducted by Nelson et al. (1993a, 1994), which examined swimming performance, the migration tests described here were more behaviorally oriented. Each fish passing a partition must make a choice to respond to the velocity encountered either by passing the partition or 
avoiding the velocity. The tank was designed to prevent fish from simply being washed downstream. In each compartment there were adequate refuges of zero velocity that a fish could occupy if it did not choose to respond to the velocity. These tests do not provide causal mechanisms for observed behaviors, but do allow examination of similar behaviors exhibited in Nelson's experiments by using a different test apparatus.

It appears movement behavior in migration tanks is influenced by water velocity and seasonality. Mean movement scores and travel rates were generally higher when water velocity was present. In addition, movement was strongest in a downstream direction for fish that were presumably still premigrants. During this time, premigrant fish in the Hanford Reach exhibited rapid growth and increases in gill ATPase activities. These factors may have contributed to increased movement during this time. In contrast, active migrants collected at McNary Dam in July and August had slower movement times to traps, moved to the traps in fewer numbers, and had higher downstream scores, indicating less downstream movement. This may be a result of fish either being in poor condition, which may affect behavior, or having decreased propensity to respond to water velocity during that time of the year. These fish were also considerably larger than the premigrants tested and may have behaved differently in the tanks. This was also a time when gill ATPase activity and river flows began to decline. However, this behavior was similar to the findings of Nelson et al. (1994) who showed subyearling chinook salmon exhibited a potential net upstream movement in August, and Giorgi et al. (1990) who recaptured marked subyearlings upstream of release locations in John Day Reservoir.

Subyearling chinook salmon that moved at night in migration experiments did so almost exclusively in a downstream direction early in the season when the water velocity was 15 and $30 \mathrm{~cm} / \mathrm{s}$. Migrants also moved downstream at night but not to the extent of premigrants in 1995. The low activity levels of fish in nighttime tests indicate that fish moved directly to the downstream traps and did not move back and forth between partitions as was often observed during the day. Although strong downstream movements were observed during the day as well, activity levels of test fish were high indicating fish may not be displaced downstream as rapidly as they might be at night.

Various environmental, physiological, and developmental factors are associated with the onset of seaward migration in subyearling chinook salmon (see reviews by Folmar and Dickhoff 1980; Hoar 1976). Although many correlative relations exist between the aforementioned variables and juvenile chinook salmon 
emigration (Beeman et al. 1991; Berggren and Filardo 1993), causal mechanisms of migration are still lacking. Nelson et al. (1993b, 1994) and Smith (1982) presented evidence that migration may result from downstream displacement brought about by reduced swimming performance. The experiments discussed here suggest a possible behavioral component to migration as well. Holistic rather that individual consideration of the results from these experiments may provide insight into mechanisms underlying survival of subyearling chinook salmon. If a window of migratory opportunity exists for fall chinook salmon, it would probably exist early in the outmigration from mid June to early July. This is a time of rapid growth and smolting as evidenced by rising gill ATPase activities, development of osmoregulatory competence, and development of a preference for sea water. In addition, fish show strong directed downstream movement at this time. A fish that possessed these attributes may gain a survival advantage by migrating under higher flows and lower river temperatures to reach the estuary at a time appropriate for its physiological development. In contrast, fish migrating later in the season do so under lower flows, higher temperatures, at greater risk to disease, and at a level of smoltification that may hinder successful seawater entry.

The best measure of juvenile salmon migratory performance is subsequent adult returns. In the early 1980s, fish that migrated early in the summer contributed more adults than later migrants (Giorgi et al. 1990). To date, fish marked early in the fall chinook outmigration at McNary Dam in 1991 have contributed nearly twice as many adults as fish marked later in the season (Tiffan, unpublished data). Additional adult return information from fish marked from 1992-1994 will clarify whether fish survive differentially during the summer outmigration, and how physiological, behavioral, and environmental attributes affect migratory performance and subsequent adult returns. 


\section{References}

Baggerman, B. 1960. Salinity preference, thyroid activity, and the seaward migration of four species of Pacific salmon (Oncorbynchus). Journal of the Fisheries Research Board of Canada $17: 295-322$.

Beeman, J.W., D.W. Rondorf, J.C. Faler, P.V. Haner, S.T. Sauter, and D.A. Venditti. 1991. Assessment of smolt condition for travel time. Annual Report to Bonneville Power Administration, Contract DE-A179-87BP35245, Portland, Oregon.

Berggren, T.J., and M.J. Filardo. 1993. An analysis of variables influencing the migration of juvenile salmonids in the Columbia River basin. North American Journal of Fisheries Management 13:48-63.

Blackburn, J., and W.C. Clarke. 1987. Revised procedure for the 24 hour seawater challenge test to measure seawater adaptability of juvenile salmonids. Canadian Technical Report of Fisheries and Aquatic Sciences 1515: $35 \mathrm{p}$.

Clarke, W.C., and J.E. Shelbourn. 1985. Growth and development of seawater adaptability by juvenile fall chinook salmon (Oncorbynchus tshaweytscha) in relation to temperature. Aquaculture 45:21-31.

Folmar, L.C., and W.W. Dickhoff. 1980. The parr-smolt transformation (smoltification) and seawater adaptation in salmonids, a review of selected literature. Aquaculture $21: 1-37$.

Giorgi, A.E., D.R. Miller, and B.P. Sanford. 1990. Migratory behavior and adult contribution of summer outmigrating subyearling chinook salmon in John Day Reservoir, 1981-1983. Final Report to Bonneville Power Administration, Contract DE-A179-83BP39645, Portland, Oregon.

Healey, M.C. 1991. Life history of chinook salmon. Pages 311393 in C. Groot and L. Margolis (editors), Pacific salmon life histories. University of British Columbia Press, Vancouver, Canada.

Hoar, W.S. 1976. Smolt transformation: evolution, behavior, and physiology. Journal of the Fisheries Research Board of Canada 33:1233-1252. 
Mazeaud, M.M., F. Mazeaud, and E.M. Donaldson. 1977. Primary and secondary effects of stress in fish: some new data with a general review. Transactions of the American Fisheries Society 106:201-212.

McInerney, J.E. 1963. Salinity preference: an orientation mechanism in salmon migration. Journal of the Fisheries Research Board of Canada 25:995-1018.

Nelson, W.R., P.G. Wagner, and D.W. Rondorf. 1993a. Subyearling chinook salmon marking at McNary Dam to estimate adult contribution. Pages 52-62 in D.W. Rondorf and W.H. Miller, editors. Identification of the spawning, rearing, and migratory requirements of fall chinook salmon in the Columbia River basin. 1991 Annual Report to Bonneville Power Administration, Contract DE-A179-91BP21708, Portland, Oregon.

Nelson, W.R., L.K. Freidenburg, and D.W. Rondorf. 1993b. Swimming behavior of subyearling chinook salmon. Pages 3051 in D.W. Rondorf and W.H. Miller, editors. Identification of the spawning, rearing, and migratory requirements of fall chinook salmon in the Columbia River basin. 1991 Annual Report to Bonneville Power Administration, Contract DE-A17991BP21708, Portland, Oregon.

Nelson, W.R., L.K. Freidenburg, and D.W. Rondorf. 1994. Swimming performance of subyearling chinook salmon. Pages 39-62 in D.W. Rondorf and W.H. Miller, editors. Identification of the spawning, rearing, and migratory requirements of fall chinook salmon in the Columbia River basin. 1992 Annual Report to Bonneville Power Administration, Contract DE-A179-91BP21708, Portland, Oregon.

SAS Institute. 1990. SAS/STAT User's Guide, Release 6.04. SAS Institute Inc., Cary, North Carolina.

Schrock, R.M., J.W. Beeman, D.W. Rondorf, and P.V. Haner. 1994. A microassay for gill sodium, potassium - activated ATPase in juvenile Pacific salmonids. Transactions of the American Fisheries Society 123:223-229.

Smith, L.S. 1982. Decreased swimming performance as a necessary component of the smolt migration in salmon in the Columbia River. Aquaculture 28:153-161. 
Tiffan, K.F., D.W. Rondorf, and P.G. Wagner. 1994a. Osmoregulatory performance and marking of subyearling chinook salmon at McNary Dam to estimate adult contribution. Pages 171-190 in D.W. Rondorf and W.H. Miller, editors. Identification of the spawning, rearing, and migratory requirements of fall chinook salmon in the Columbia River basin. 1992 Annual Report to Bonneville Power Administration, Contract DE-A179-91BP21708, Portland, Oregon.

Tiffan, K.F., and P.G. Wagner. 1994b. Osmoregulatory performance and marking of subyearling chinook salmon at McNary Dam to estimate adult contribution. Pages 108-131 in D.W. Rondorf and K.F. Tiffan, editors. Identification of the spawning, rearing, and migratory requirements of fall chinook salmon in the Columbia River basin. 1993 Annual Report to Bonneville Power Administration, Contract DE-A17991BP21708, Portland, Oregon.

Tiffan, K.F., R.D. Garland, and P.G. Wagner. 1996. Osmoregulatory performance, migration behavior, and marking of subyearling chinook salmon at McNary Dam to estimate adult contribution. Pages 99-127 in D.W. Rondorf and K.F. Tiffan, editors. Identification of the spawning, rearing, and migratory requirements of fall chinook salmon in the Columbia River basin. 1994 Annual Report to Bonneville Power Administration, Contract DE-A179-91BP21708, Portland, Oregon.

Wagner, H.H., F.P. Conte, and J.L. Fessler. 1969. Development of osmotic and ionic regulation in two races of chinook salmon Oncorbyncbus tshawytscba. Comparative Biochemistry and Physiology 29:325-341.

Zar, J.H. 1984. Biostatistical analysis. Prentice-Hall, Inc. Englewood Cliffs, New Jersey.

Zaugg, W.S., and B.R. Beckman. 1990. Saltwater-induced decreases in weight and length relative to seasonal gill $\mathrm{Na}^{+}-\mathrm{K}^{+}$ATPase changes in coho salmon (Oncorbynchuskisutch) : a test for saltwater adaptability. Aquaculture 86:19-23. 